\title{
WIRES WATER
}

\section{Article type: Overview}

\section{Article title: Modelling plant-water interactions: an ecohydrological overview from the cell to the global scale}

\section{Authors:}

Full name and affiliation; email address if corresponding author; any conflicts of interest

\author{
Simone Fatichi \\ Institute of Environmental Engineering, ETH Zurich, Zurich, Switzerland, \\ simone.fatichi@ifu.baug.ethz.ch \\ Christoforos Pappas \\ Institute of Environmental Engineering, ETH Zurich, Zurich, Switzerland \\ Valeriy Y. Ivanov \\ Department of Civil and Environmental Engineering, University of Michigan, Ann Arbor, \\ MI, USA
}

\section{Abstract}

Vegetation and the water cycle are inherently coupled across a wide range of spatial and temporal scales. Water availability interacts with plant ecophysiology and controls vegetation functioning. Concurrently, vegetation has direct and indirect effects on energy, water, carbon, and nutrients cycles. A better understanding and modelling of plant-water interactions demands for highly interdisciplinary approaches. We present an overview of the main processes and relevant interactions between water and plants across a range of spatial scales, from the cell level of leaves, where stomatal controls occur, to drought stress at the level of a single tree, up to the integrating scales of a watershed, region, and the globe. A review of process representations in models at different scales is presented. More specifically, three main model families are identified: (i) models of plant hydraulics that mechanistically simulate stomatal controls and/or water transport at the tree level; (ii) ecohydrological models that simulate plot- to catchment-scale water, energy and carbon fluxes; and (iii) terrestrial biosphere models that simulate carbon, water, and nutrient dynamics at the regional and global scales and address feedbacks between Earth's vegetation and

This is the author manuscript accepted for publication and has undergone full peer review but has not been through the copyediting, typesetting, pagination and proofreading process, which may lead to differences between this version and the Version of Record. Please cite this article as doi: 
the climate system. We identify special features and similarities across the model families. Examples of where plant-water interactions are especially important and how they have led to key scientific findings are highlighted. Finally, we discuss the various data sources that are currently available to force and validate existing models and we present perspectives on the evolution of the field.

\section{Introduction}

Transpiration is the process of water transfer from soil to the atmosphere through plant tissues, during this process water changes its phase and exits from the plant. On average, transpiration amounts to roughly $40 \%$ of the land precipitation ${ }^{1,2,3}$ and the correspondent latent heat constitutes about $38 \%$ of the net radiation absorbed by the land surface ${ }^{4}$. Therefore, it is not surprising that vegetation plays a fundamental role in hydrology and climatology ${ }^{5,6}$. Transpiration occurs almost entirely through small openings in the leaves called stomata ${ }^{7}$. This pathway is the same through which plants acquire carbon and thus represents a major nexus between hydrology and the carbon cycle. Plants lose about 100-500 molecules of water to fix one molecule of $\mathrm{CO}_{2}{ }^{8}$, with water representing a key element determining vegetation function and performance. The coupling of transpiration and photosynthesis creates important feedbacks between water, carbon, and nutrient cycles. Soil biogeochemistry and nutrient dynamics are in fact directly connected to water availability, because soil biota dynamics and rock weathering depend on soil moisture content ${ }^{9,10}$, and also indirectly, through the effect that soil water content has on vegetation growth and litter production. Despite the strong connection between vegetation and hydrology, historically, in hydrological applications, vegetation has been represented with constant factors embedded in equations for computing bulk evapotranspiration, as for example in the Penman-Monteith equation ${ }^{11}$. Concurrently, in many ecological applications with detailed characterization of plant processes, hydrology has been represented with a simple bucket approximation ${ }^{12,13}$.

Given the central role of water-plant interactions in the climate system, representations of vegetation attributes and especially stomatal functioning were included in early Earth System Models (ESMs) $)^{13,14,15,16}$. Since then, in the last two decades, ecohydrology (or hydroecology) has been an emerging scientific field, as testified by the growth of the number of published articles and citation metrics beyond the average increase in scientific productivity (Fig. 1). This has been also the result of the emphasis placed on water-vegetation interactions in a series of seminal works ${ }^{17,18,19,20}$. Ecohydrology has been less recognized as an emerging field in ecology, because many ecologists and ecophysiologists would have regarded themselves as "ecohydrologist" well before this term became popularized by hydrologists ${ }^{21}$. Notwithstanding, the emergence of ecohydrology as a welldistinguished discipline helped a better exchange and an explicit linkage between the two scientific communities. Along with the emergence of ecohydrology, an increasing number of quantitative studies focusing on the carbon, water, and nutrient cycles, at the regional and global scales, have appeared within the realm of "biogeosciences", under the growing pressure to better understand carbon cycle feedbacks to climate chang $\mathrm{e}^{22,23,24}$. There are studies nowadays in which the boundaries between the fields of ecohydrology, ecophysiology, and biogeosciences are very subtle and mostly a 
matter of spatiotemporal scales. Beyond affecting water, carbon, and nutrient cycles, vegetation functioning has important implications for addressing other relevant questions, as for example in assessments of land-use change impacts ${ }^{25}$, evaluation of ecosystem services ${ }^{26}$, soil resources and landscape formation ${ }^{27}$, as well as crop productivity ${ }^{28}$. These are all topics where water availability interacts with plant ecophysiology to produce complex dynamics, which are unlikely to be uncovered with narrowly disciplinary approaches that ignore or trivialize either hydrological or vegetation components. Clearly, the perception of significance and integration of vegetation processes into various fields of environmental research has recently undergone a significant transformation.

It is important to underline that ecohydrology should not be regarded as the analysis of how vegetation properties and organization affect streamflow. It is a broader discipline that examines the two-way interactions between the entire hydrological cycle and plant functioning. When the main interest is on relatively short-term ( $\approx$ decade) analyses of streamflow and water availability or in hydrological engineering design, classic hydrological tools such as the Penman-Monteith equation can often suffice the purpose of representing vegetation and approaches that involve multiple processes and feedbacks such as carbon cycle or plant physiology are unlikely to improve considerably predictive capabilities or specific design criteria. However, when the focus shifts toward land-surface climate feedbacks, carbon and nutrients cycles or the aim is to elucidate ecological mechanisms through which water availability affects vegetation functioning, then the necessity of explicitly accounting for vegetation physiology and anatomy and/or soil biogeochemistry becomes extremely relevant. Furthermore, feedbacks between vegetation and water cycle cannot be captured, if these are not explicitly represented in models, and hypothesis testing can be severely impaired by simplified model structures. An illustrative example is provided by potential effects that model complexity and explicit consideration of elevated $\mathrm{CO}_{2}$ feedbacks can have in evaluating drought trends $\mathrm{s}^{29,30}$ or aridity projections in a changing climate ${ }^{31,32}$. Too simple representation of vegetation has been shown to provide quite misleading assessments. Another example is represented by the study of the effects of land cover change (e.g., deforestation, grassland management) on evapotranspiration and streamflow. Detailed numerical analyses ${ }^{25,33}$ and actual observations $s^{34,35,36}$ suggest that the impact of land cover change on the hydrological cycle, may be typically less pronounced in comparison to results obtained with model simulations using simplified approaches (e.g., ${ }^{37}$ ), or from small scale manipulation experiments ${ }^{38}$. However, if the effects of disturbances or long-term analyses ( $\approx$ multiple decades) are sought, water cycle is more tightly connected to the vegetation cover (e.g. ${ }^{39,40}$ ). For instance, shifts in forest composition due to species-specific mortality have been shown to produce hydrological relevant consequences ${ }^{41}$. The latter is the result of processes typically unaccounted for in classic ecohydrology such as soilbiogeochemistry, forest demography, and disturbances, which therefore may represent fundamental "ecohydrological" components. Another example of ecohydrological links among vegetation, energy, and water cycle is vegetation-snow interaction. Plant canopy that intercepts snow typically favors sublimation, thereby reducing the amount of snowpack at the ground. Vegetation also alters the radiation balance, shading ground snowpack from direct radiation, yet typically increasing the longwave radiation reaching the ground during snow melting periods ${ }^{42,43,44}$. 
Additionally, the presence of vegetation affects the turbulent exchanges modifying the wind profile ${ }^{45,46}$. All of these processes are highly non-linear and can contribute to the increase or decrease of total snow-melt below vegetation, when compared to cleared areas ${ }^{47}$.

In this overview, we provide an essential description of the main processes and relevant interactions between water and plants across a range of spatial scales, from the cell level of leaves, where stomatal controls occur, to drought stress at the level of a single tree; up to the integrating scales of a watershed, region, and the globe (Fig. 1). We treat only terrestrial ecosystems and leave aside aquatic plants in water bodies and oceans ${ }^{48}$. Water controls are also regarded from the plant perspective and therefore issues related with vegetation as mechanical roughness element and its effect on modulating river and overland flows ${ }^{49,50,51}$ are not addressed. In combination with the description of the physical and ecological processes, we also refer to models available in literature that simulate specific processes at the different scales. We only focus on those models that simulate the temporal and, eventually, spatial dynamics of key vegetation states (e.g., Leaf Area Index, LAI). With the above constrain, we do not explicitly discuss steady-state models and analytical derivations (e.g., ${ }^{52,53,54,55,56,57}$ ), which have led to considerable advances in the understanding of plant water interactions but are less amenable to address real case studies. Models developed in forestry research for simulating long-term ( $\approx$ century) forest succession and management ${ }^{58,59}$ are also excluded because of the rather minimalistic representation of hydrological processes. Finally, we favour models with a certain degree of generality that can be applied beyond the specific conditions for which they were derived.

Examples where plant-water interactions are especially important and have already led to key scientific findings are presented. We also focus on which data are currently available to force and validate the existing models, concluding with perspectives on the evolution of the field.

\section{Cell to plant scale}

Plants developed a vascular system consisting of non-living and living cells, in which water, carbohydrates, and nutrients can move without an active "pump" such as a heart, designed to control and coordinate such movements ${ }^{60}$. Vascular plants need to solve the problem of water and nutrient transport from soil to different plant organs, especially leaves, which are exposed to continued dehydration because of partial contact with the sub-saturated atmosphere through stomatal apertures. Concurrently, plants have to transport the products of photosynthesis, such as sugars, from the leaves to the other living organs. To overcome the lack of a central pump, plants exploit physical gradients in water potential (the energy state of water ${ }^{61}$ ) and concentrations of osmotic substances ${ }^{62}$. The mechanisms for water entering the roots and leaving the leaves are described in Section "Stomatal Controls" and "Root controls", while in Section "Plant Vascular Transport" we provide the key elements of water transport mechanisms within plants. Fluxes of water or mass are expressed using a "flux-gradient" relation, where the flux is proportional to a gradient in the "concentration" of the driving quantity, times a conductance term. Throughout the 
text, we reference existing models with different degrees of approximation of the current process understanding. We refer the reader to more specific reviews and books for a complete treatment of plant physiology and plant vascular transport ${ }^{8,63,64,65,66,67}$.

\section{Stomatal controls}

Leaves are the sites where water transported from the xylem, i.e., the non-living vascular conduits of plants used for water transport from roots to leaves, is evaporated (commonly referred to as "transpired") to the atmosphere. At the same time, carbon from the atmosphere is assimilated through the photosynthetic reaction, which takes place in the chloroplasts, mostly located in the mesophyll cells ${ }^{68,69,70}$ [Box 1]. Water is transported to the terminal part of the xylem network in the leaf veins, while carbon is loaded and exported in the opposite direction in the phloem (the vascular conduits that transport sugars produced by photosynthesis to other tissues in the plant, Fig. 2). Stomatal size and density and leaf venation have been recognized to be important for plant functioning and evolution ${ }^{71,72,73}$. At the same time the bulk of the resistance to water transport in the leaf is occurring outside the venation network ${ }^{74,75,76}$. Transpiration to the external atmosphere takes place through stomatal apertures of few micrometers in size $(2-40 \mu \mathrm{m})$, mostly located in the lower side of the leaf ${ }^{7,77}$. Stomatal apertures are the common pathways for water and carbon fluxes and therefore represent one of the most essential linkages between ecological and hydrological dynamics. There is a large amount of literature on environmental factors influencing stomatal aperture, such as light, temperature, $\mathrm{CO}_{2}$, vapour pressure deficit ${ }^{78,79,80,81}$ but despite the critical role that stomata play, the details of their regulation are still not fully understood ${ }^{82}$. Ultimately, stomata are largely biologically regulated and it is through these tiny apertures (or lack of thereof, if leaves are shed) that vegetation imprints a unique signature on the water cycle.

Each stoma is surrounded by a pair of guard cells that are, in turn, in contact with multiple epidermal cells (Fig. 2). Stomata tend to open when guard cells increase their turgor (the sum of water potential and osmotic pressure, see equation (4)), while an increase in epidermal cell turgor plays in the opposite direction, exerting a hydromechanical negative feedback ${ }^{83,84,85}$ (Fig. 2b). Since the guard cell turgor is the sum of osmotic pressure and water potential, stomatal aperture is controlled by both hydraulic and chemical factors ${ }^{86}$ (Fig. 2c). Stomata close when water potential in the leaf drops, because of a large transpiration flux or low water potential in the upstream xylem conduits $87,88,89$. The hydraulic control acts directly in the reduction of guard cell turgor, while chemical signals are less well quantified ${ }^{90}$. However, it is well established that chemical factors are essential for stomata opening in response to light ${ }^{91,92,93}$. Furthermore, chemicals compounds, such as Abscisic Acid (ABA), are typically released in response to water stress from the leaves and roots ${ }^{94,95,96}$ and contribute to a reduction in the stomatal aperture ${ }^{97}$. Release of $A B A$ is an important evolutionary trait since in early plants such as lycophyte and ferns, stomata closure is purely hydraulically controlled ${ }^{98}$. A differential sensitivity of stomata aperture to chemical compounds is a likely explanation why certain plants close stomata considerably in response to dehydratation, keeping a fairly constant leaf water potential (commonly referred to as "isohydric behaviour"), while others tend to keep stomata open 
to favour carbon assimilation, experiencing larger fluctuations and lower values of the leaf water potential ("anisohydric behaviour").

Models have been presented to describe mechanistically stomatal behaviour and reproduce the hydraulic dynamics in the leaf $84,99,100,101,102,103,104,105,106$ or simply to reproduce functional relations in agreement with observations ${ }^{78,107,108}$. Representing in models the exact mechanisms through which stomata respond to the external environment and chemical signals ${ }^{109,110,111}$ still represents an open research frontier. Mechanistic models have been mostly applied in plant physiological studies, while ecohydrological models and ESMs adopted empirical/conceptual solutions, where different environmental factors are treated independently ${ }^{78}$, or the stomatal conductance $\left(g_{s}\right)$ is assumed to be proportional to carbon assimilation $\left(A_{n}\right)$ and inversely related to leaf interior $\mathrm{CO}_{2}$ concentration $\left(c_{i}\right)$ and Vapour Pressure Deficit (VPD). These are for instance the structures of the Ball-Berry ${ }^{112}$ and Leuning equations ${ }^{113,114}$ :

$g_{s}=g_{0}+a \frac{A_{n}}{C_{i}-\Gamma} f(V P D)$

where $g_{0}$ is the residual (or "leakage") stomatal conductance, when $A_{n}$ is equal to zero, $a$ is an empirical parameter and $\Gamma$ is the $\mathrm{CO}_{2}$ compensation point, i.e., the concentration of $\mathrm{CO}_{2}$ at which the rate of carbon dioxide uptake is exactly balanced by the rate of carbon dioxide release in respiration. The Leuning equation (Eq. 1) is widely used and typically requires an estimate of net assimilation $A_{n}$, which is carried out using biochemical models of photosynthesis, such as the Farquhar model or its subsequent refinements ${ }^{115,116,117,118,119}$.

An alternative approach to characterizing stomatal regulation is to assume that stomatal aperture is regulated to maximize carbon gain, while minimizing water loss ${ }^{120,121}$. These approaches, known as "optimality arguments" are appealing from theoretical standpoint because they are based on ecological evolutionary principles and seem to be corroborated by observed stomatal behaviour ${ }^{121}$. However, they require specific assumptions for the optimality function and temporal and spatial scales of integration, which all have been questioned ${ }^{82}$. Specific formulations of the optimality principle lead to different analytical expressions for leaf-scale conductance ${ }^{122,123,124}$ and the approach starts to be also adopted in ESMs ${ }^{125}$. Note that most of the models referenced above do not directly account for effects induced by plant water stress beyond VPD, which needs to be introduced empirically, by either directly modifying $g_{s}$, or the parameters of the biochemical photosynthesis model $^{126,127}$, or some of the terms in the analytical form of optimal stomatal conductance ${ }^{128}$.

\section{Root controls}

Roots represent an interface between plants and soil, providing entrance and initially distributed pathways for fluxes of water and nutrients from the external environment to the plant. The soil environment surrounding the root is called "rhizosphere" and can present strong gradients of water potentials and nutrient concentrations ${ }^{129,130,131,132}$. Roots with diameters smaller than $2 \mathrm{~mm}$ are 
generally defined as "fine roots", while roots of larger diameter are named "coarse roots". Fine roots are mostly composed of living tissues and are essential for the uptake of water and nutrients, while coarse roots serve as aggregated conduits for transport and structural stability of the plant ${ }^{133,134}$. Water flows into the roots because the water potential is typically larger in the soil than inside the plants ${ }^{135}$. Situations of reverse flow from roots to soil may also occur and are typically referred to as "hydraulic redistribution"136,137. There is still a debate as to whether the phenomenon is a part of typical plant life process or confined to specific conditions, however it is generally believed that it is of considerably smaller magnitude than water uptake ${ }^{138}$. Water moves from the soil to the inner part of fine roots overcoming a barrier called Casparian strip mostly composed of suberin for isolating the plant interior, preventing for instance the entrance of pathogens. Afterwards, water movement continues across cell cytoplasm (sympalstic pathway) or through cell walls (apoplastic pathway) and reach the xylem and therefore the vascular network, where it can flow to the main stem ${ }^{139,140,141}$. Given a certain plant demand, water uptake is a function of the rhizosphere water potential distribution, axial and radial root conductivities, and the three-dimensional architecture of the root system $^{142,143,144}$. The axial and especially the radial conductivities to water flow are not constant, but vary with water potential and can be partially chemically controlled by the plant through aquaporins ${ }^{145,146}$, even though the exact mechanisms underlying this control are still uncertain. Nutrient uptake can be passive and follows water uptake or can be enhanced through osmotic gradients at the root interface or by the synthesis of various specialized transporters that are dynamically integrated into the cell membrane ${ }^{147,148,149}$.

The variability in soil water potential, axial and radial conductivities, and three-dimensional root architecture (Fig. 3 ) is preserved in a number of plant-scale models that generally have a specific emphasis on root processes ${ }^{150,151,152,153,154,155,156,157}$. The most common approach in ecohydrological models and ESMs is to consider only root depth (zero-dimensional model), in combination with some empirical function of water content or water potential limiting water uptake or transpiration in conditions considered to be "water stress"157,158,159. Several models started considering also the vertical distribution of root biomass (one-dimension ${ }^{160,161}$ ), and others include a bulk soil-to-root conductance ${ }^{162,163}$, which is a function of the amount of roots expressed through some index such as root-length-index or root-area-index ${ }^{164}$. A hybrid approach has been recently developed that preserves three-dimensional information and hydraulic conductivities in a simplified form ${ }^{143}$, and may represent an important way forward in representing hydraulic relations (and constraints) in describing the process of plant water uptake. However, an important limitation in studies of root functioning and uptake capacity is in extreme challenge of instrumenting and monitoring roots in field conditions, which has likely prevented the development of a larger number of models or conceptualization of intermediate complexity.

\section{Plant vascular transport}

It is currently accepted by the scientific community that water movement in the xylem is governed by the cohesion-tension theory ${ }^{60,165,166}$, while the flow of water in the phloem follows the Münch 
hypothesis ${ }^{167,168,169}$. According to the cohesion-tension theory, water molecules are transported in the plant in a metastable state generated by surface tension at the air-water interfaces in the leaves, the tension is transmitted throughout the entire water column in the plants and molecules remains cohesive among themselves and adherent to the walls because of the small size of conduits and cells. Under extreme negative potentials or external perturbations, water transport can be interrupted by formation of air bubbles (the process of cavitation) and thus the plant vascular transport becomes impaired ${ }^{166}$.

The water flow in the xylem in the vertical, upward direction $\left(\mathrm{J}_{\mathrm{xy}}\right)$ in a conduit of length $(\Delta \mathrm{L})$ can be expressed through a "flux-gradient" relation as the product of the xylem conductivity $\left(\mathrm{K}_{\mathrm{xyl}}\right)$ and the gradient of water potential $\left(\Delta \Psi_{x y l}\right)$ minus the gravitational potential $(\rho g \Delta z)$ :

$J_{x y l}=K_{x y l}\left(T, \Psi_{x y l}\right) \frac{\Delta \Psi_{x y l}-\rho g \Delta Z}{\Delta L}$

where the xylem conductivity $\mathrm{K}_{\mathrm{xyl}}$ is a plant/tissue specific parameter, which varies with temperature $(T)$, because temperature affects the water viscosity, and water potential itself. The dependence of $\mathrm{K}_{\mathrm{xyl}}$ on the water potential is typically described with a sigmoidal shape and it is particularly important because it defines the resistance to cavitation, i.e., the formation of air bubbles (embolism) in the xylem. Cavitation implies a reduction of the conductive capacity of the xylem conduits $^{170,171,172,173}$, typically indicated as Percentage Loss of Conductivity (PLC) (Fig. 4). The xylem vulnerability curve (PLC versus $\Psi_{\mathrm{xy}}$ ) can be described by the knowledge of the water potential at 50 $\%$ loss of conductivity $\left(\Psi_{x y 1,50}\right)$ and of another characteristic value (e.g., $\left.\Psi_{x y l, 12}\right)$, typically correlated to $\Psi_{x y 1,50}{ }^{174,175}$. The term $J_{x y l}$ is referred to as sapflow and can be measured directly in the plants with various methods ${ }^{176}$.

Similarly, following the Münch hypothesis of a turgor-pressure driven flow, the water flux in phloem in the vertical downward direction $\left(\mathrm{J}_{\mathrm{phl}}\right)$ in a conduit of length $(\Delta \mathrm{L})$ is driven by the gradient of turgor $\left(\Delta \mathrm{P}_{\mathrm{phl}}\right)$ plus the gravitational potential $(\rho \mathrm{g} \Delta \mathrm{z})$ times the phloem conductivity $\left(\mathrm{K}_{\mathrm{phl}}\right)$, which depends on temperature and on the concentration of osmotic solutes in the phloem $\left(C_{\text {phl }}\right)$ because sucrose concentration affects the fluid viscosity ${ }^{177}$ (Fig. 4):

$$
J_{p h l}=K_{p h l}\left(T, C_{p h l}\right) \frac{\Delta P_{p h l}+\rho g \Delta Z}{\Delta L}
$$

The turgor $(P)$ is defined as the sum of osmotic pressure $(\Pi)$, directly related to the concentration of osmotic solutes through the van't Hoff relation or other empirical functions ${ }^{178,179}$ and water potential $^{180,181}$ :

$$
P=\Pi+\Psi
$$

Conversely to sapflow, phloem flow is particularly challenging to measure due to the size of the phloem tissue and to the disturbances induced by the measurement itself. It has been only 
measured in laboratory experiments ${ }^{65,182}$, although promising techniques for field measurements are emerging ${ }^{183}$.

In order for the water transport to occur, there should be a difference larger than the gravitational potential in the water potential between roots and leaves, which is typically the case during daytime in the growing season. Water is not only exchanged vertically in the phloem and xylem but it can move also radially between phloem and xylem and between storage reserves (mostly composed by living părenchyma cells residing near xylem conduits) and the xylem. These exchanges make xylem and phloem hydraulically coupled ${ }^{184,185}$ and confer to the plant a given capacitance in absorbing fluctuations between the water demand of the leaves (transpiration) and the water uptake from the roots $^{186,187,188,189,190}$. Capacitance is typically more significant in stems of larger trees ${ }^{191}$ and it is due to a combination of elastic shrinkage and swelling of phloem, living bark and xylem tissue, and due to the release of water from "stiff" storage in the parenchyma cells near the xylem. Elastic shrinkage and swelling of the tree is the main mechanism to release stored water in young trees, but it becomes marginal in older trees where larger "stiff volumes" of stored water are the main contributors to tree capacitance ${ }^{192,193}$. In both young and old trees, the elastic behaviour of xylem and phloem is large enough to be clearly measured with high-resolution dendrometers ${ }^{183,194,195}$, that can therefore provide important information on plant hydraulic behaviour ${ }^{196,197,198}$. Time-scales through which capacitance can buffer the difference between root water uptake and transpiration demand are confined to less than an hour for small young trees and in the order of several hours, or even days during droughts, for large old trees ${ }^{190,199}$.

Only few models have been currently presented to describe plant vascular transport in detail, since the prevalent option has been to lump the entire plant system in a single conductance or resistance term ${ }^{200}$ or to ignore plant hydraulics completely, and use the root zone soil water potential to directly simulate the controls at the leaf level (the case of ecohydrological models and ESMs, but see $\left.^{125}\right)$. Important exceptions are the Sperry model ${ }^{140}$ and the TREES model ${ }^{201,202}$, which use a series of resistances from the soil to the leaves and xylem vulnerability curves to describe plant hydraulic behaviour; the FETCH model ${ }^{203}$, the XWF model ${ }^{204,205,206}$, and the model presented by Chuang et al. $2006^{207}$, which described water flow through the plants with a porous media analogy using the onedimensional Richards equation for the water potential along the hydraulic path. Attempts to include numerical descriptions of phloem transport, tissue growth, and diameter variations have been even more rare, although important examples are available with different degrees of complexity ${ }^{177,208,209,210,211,212,213,214}$, as follow up of first pioneering attempts ${ }^{215}$.

\section{Plant physiology during a progressive drought}

When the soil water potential near the roots decreases (or VPD substantially increases), a plant may be unable to fully satisfy the transpiration demand and thus progressively enters into a phase of water stress. This is characterized by a drop of water potential throughout the various plant compartments, accompanied by a reduction of turgor in living tissues, since the plant is only partially able to compensate for lower water potentials through osmotic adjustments ${ }^{216,217,218}$. The first 
process to be affected by the low water potentials is growth (Fig. 5). Cell growth is mostly the result of cell division, enlargement, and cell wall synthesis ${ }^{219,220}$. Cell enlargement is a function of turgor pressure ${ }^{181,221,222,223}$. A small reduction of water potential can decrease significantly or stop the growth well before photosynthesis or stomatal conductance are affected $224,225,226$. As the growth stops, respiration associated with the growth also ceases ${ }^{227,228}$. Growth impairment has been often neglected by ecohydrological literature and models but, in fact, it represents the first consequence of water stress onset.

If water potential continues dropping, plants need to preserve sufficiently high water potentials to avoid catastrophic levels of cavitation and thus start reducing the stomatal conductance (see Section "Stomatal Controls"). A reduction of stomatal conductance typically leads to a decrease in gas exchanges, e.g., photosynthesis and transpiration. These are the controls, which have been typically placed at the foundation of ecohydrology ${ }^{18}$ and embedded in ESMs ${ }^{16}$. The decrease in turgor and photosynthesis further modifies the plant metabolism and carbon allocation strategies ${ }^{229,230}$. The decrease in transpiration alters the leaf energy budget, with lower latent heat and higher sensible heat fluxes and eventually higher emitted longwave radiation because, given constant forcing, leaf temperature tends to increase with lower stomatal conductance. A similar response in the energy budget is observed also at canopy or larger spatial scales ${ }^{231}$.

If the drought persists further, plant vascular transport is also affected because the leaf and xylem conductivities decrease at water potentials low enough to allow the formation of emboli and thus cavitation in the xylem conduits (Section "Plant Vascular Transport", Fig. 5). At relatively low water potentials, leaves lose turgor and the photosynthetic machine starts to be structurally damaged ${ }^{218,232,233}$. At this stage, roots can also become completely disconnected from soil, a process typically unaccounted for in models (but see ${ }^{202}$ ). Maintenance respiration has also been found to decrease as the drought progresses 228,234 . This is probably due to a slow-down of metabolic activities, although specific mechanisms are yet not fully understood. It is indeed not rare that plants start to shed leaves when exposed to a long-lasting severe drought ${ }^{235,236}$. For some plants, such as droughttolerant deciduous trees, this is actually a routinely adopted strategy $237,238,239$.

The decrease or even cessation of photosynthesis poses a challenge for the plant that is called to rely only on non-structural carbohydrate reserves (NSC) for its maintenance. Permanent hydraulic failure of vascular transport and carbon starvation due to exhaustion or impossibility to access NSC, or a combination of these mechanisms have been hypothesized as reasons for plant mortality ${ }^{240,241}$. Recent evidence supports an earlier occurrence of hydraulic failure and a consequent blockage of NSC transport ${ }^{234,242}$. Regardless of the exact mechanisms, a severe and extended drought unavoidably leads to plant mortality, a phenomenon occurring in many ecosystems worldwide, even in those that are not typically associated with droughts $243,244,245$. This is particularly relevant since drought stress conditions can be potentially exacerbated by higher temperatures and VPD in the future ${ }^{246,247,248}$. Given the fact that the exact mechanisms that lead to plant mortality are still unknown, its modelling is a daunting task ${ }^{249,250}$ and represents an important challenge for improving 
models of water-vegetation interactions. Widespread plant mortality can in fact lead to a considerable shift in species composition and/or vegetation cover fraction, with potentially longlasting consequences for surface energy exchanges and the water cycle, even though recent observations suggest that observed changes may be smaller than expectations in several ecosystems ${ }^{35,36,251}$.

\section{Plot to catchment scale}

Historically, vegetation was included in land-surface and hydrological models because it affects transpiration through surface roughness, albedo, and canopy resistance $r_{c}=r_{s} / L A l$, where $r_{s}=1 / g_{s}$ is the reciprocal of stomatal conductance. Through $r_{c}$ vegetation modifies water and energy exchanges at the land-surface because it may offer a larger resistance between soil and atmosphere with respect to bare ground in well-water conditions, and a lower-resistance in dry conditions accessing through roots relatively deep water storages. The well-known Penman-Monteith equation ${ }^{11,252}$ accounts for these vegetation properties and it has been widely used in hydrological models. In its basic form it provides a static representation of vegetation functioning in space and time, which has been recognized to be a severe limitation in numerous contexts (e.g. ${ }^{160,253}$ ) but still provides a reasonable approximation for many other studies ${ }^{254}$. Consequently, models that solve explicitly and simultaneously hydrological and vegetation dynamics (Box 2) have been presented in the last fifteen years (Table 1). In literature, the definition of "ecohydrological model" has been used in very different contexts, and in this article we refer to ecohydrological models as those models that evolve in time and eventually in space some of the key vegetation states and concurrently solve the water budget. In the simplest case, they only dynamically simulate canopy resistance or LAI, while in the most complex case, a series of carbon pools and vegetation attributes (e.g., plant height, or root density) are prognostically simulated. Note that with the above definition we do not include steadystate models and analytical derivations (e.g., ${ }^{52,57}$ ). Rather than describing each ecohydrological model separately, a non-exhaustive list of models is presented in Table 1. In the following, we summarize processes that these models represent. Ecohydrological models typically solve water, energy, carbon, and, quite rarely, nutrient cycles at the land surface (Fig. 6).

\section{Water budget}

In terms of water budget, models use precipitation as input that can be partitioned to rainfall and snowfall. Liquid precipitation can fall directly on the ground or be intercepted by the canopy, where it can subsequently evaporate or drip. Depending on the intensity of water flux reaching the ground and on soil water content (or, more appropriately, water potential) near the surface, water can either infiltrate into the soil, or run off from the surface. Solid precipitation can fall directly to the ground or become intercepted by vegetation where it can sublimate or subsequently fall to the ground. Snow accumulates on the ground in the form of snowpack, where it melts or sublimates. Water in the soil undergoes vertical and horizontal redistribution following gravitational and capillarity gradients, typically modelled with the Richards equation ${ }^{255,256,257}$. Depending on the 
vertical profile of soil water potential and plant demand, water is evaporated from the surface as ground evaporation, or taken up by plants and transpired. Since water storage in the plants is typically ignored, root uptake and transpiration are exactly the same flux in most of the models. Water that percolates to deeper layers or into fractured bedrocks remains mostly inaccessible for plants (but see ${ }^{258}$ ) and typically contributes to aquifer recharge first, and streamflow at a later stage. In models that do not have an explicit representation of the spatial dimension, this water is subtracted from the water budget as "deep leakage" or "recharge". In models with an explicit spatial representation, after reaching the stream network as surface or sub-surface flow, water is routed through channel network downstream to a specified outlet.

\section{Energy budget}

Latent heat flux is the energy equivalent of the sum of all water vapour fluxes (transpiration and evaporation), therefore it makes the water and energy cycles tightly coupled. Models that solve explicitly the energy budget compute the latent heat flux and its partition into the different components (evaporation and transpiration) concurrently with the water budget (e.g., ${ }^{160,161,259,260,261,262}$ ). Latent heat flux $(\lambda E)$ is typically solved assuming conservation of energy in a given domain:

$$
R_{n}-H-\lambda E-G-\lambda_{p} A_{n}-A_{H}=\frac{d S}{d t}
$$

where $R_{n}$ is the net radiation, $H$ is the sensible heat flux, $G$ is the ground heat flux, $\lambda_{p}$ is the specific energy consumed in the process of photosynthesis $\left(A_{n}\right), A_{H}$ is the advected energy to the domain either from lateral or vertical fluxes and $\mathrm{dS} / \mathrm{dt}$ is the change in the energy stored into the system. Most of the models assume negligible storage capacity of energy, i.e., $\mathrm{dS} / \mathrm{dt}=0$, and also neglect the last two terms of the left hand side of eq. (5). Even with this assumption, the problem remains difficult to solve because all of the energy fluxes depend on one or, generally, more prognostic surface temperatures (e.g., soil, and sunlit and shaded canopy temperatures). Models that do solve the energy budget face the problem of solving one or a system of non-linear equations embedded in eq. (5), to derive the unknown surface temperature(s). This operation is typically quite computationally demanding. Therefore, several ecohydrological models still use simplified solutions of the energy budget such as the Penman-Monteith or Priestly-Taylor equations (e.g., ${ }^{263,264,265,266}$ ).

\section{Carbon budget}

The carbon cycle is linked to the water and energy cycles, because carbon assimilated through photosynthesis uses the same pathway between outer atmosphere and leaf interior as transpired water (see Section "Stomatal controls") and because changes in vegetation properties (e.g., plant height and LAI) modify boundary conditions for energy and water exchanges (Fig. 6). For instance, change in LAI modifies interception capacity, energy absorption and emission, as well as roughness;

a change in photosynthetic rate, $A_{n}$ (Eq. 1) may change stomatal conductance and therefore 
transpiration. The computation of carbon assimilation can be carried out with various degrees of complexity. Some models use a biochemical model of photosynthesis, in which $A_{n}$ and leaf internal $\mathrm{CO}_{2}$ concentration $\left(\mathrm{c}_{\mathrm{i}}\right)$ are computed as prognostic variables in a non-linear equation (e.g., ${ }^{160,161 \text {, }}$ ${ }^{259,261,267}$ ), others have simpler approaches exploiting the Water Use Efficiency (WUE; i.e., the ratio between net carbon assimilation and transpiration ${ }^{268}$ ) or Light Use Efficiency (LUE; i.e., the efficiency through which radiation absorbed by vegetation is converted into carbon ${ }^{269}$ ) concepts that link empirically carbon assimilation to the transpired water or intercepted light (e.g., ${ }^{262,266,270,271,272}$ ). In some ecohydrological models, vegetation dynamics are essentially reduced to the simulation of carbon assimilation only (e.g. ${ }^{267,273}$ ). In others, the assimilated carbon is used to grow plants and to evolve a given number of carbon pools. Carbon pools are the way models accounts for the size and dynamics of different plant compartments ${ }^{274}$. The number of carbon pools varies from model to model but a typical set is composed at least of a foliage pool, a fine-root pool, a sapwood or stem pool, and, more recently, a carbon reserve pool (e.g. ${ }^{161,265}$ ). Carbon reserves have been ignored in early ecohydrological and ESMs with rare exceptions (e.g. ${ }^{275}$ ) but it is currently recognized that plant dynamics cannot be simulated meaningfully without accounting for carbon reserves ${ }^{276,277,278}$. Models that use carbon pools can also simulate the dynamics of the biophysical structure of vegetation, e.g., LAl, vegetation height, root biomass.

\section{Soil biogeochemistry}

Water, energy and carbon fluxes are additionally connected through soil biogeochemistry and nutrient dynamics (Fig. 6). Soil biogeochemistry is typically simulated accounting for a given number of carbon and nitrogen pools ${ }^{279}$. Other nutrients, such as phosphorous, sulphur, or potassium are not typically included in ecohydrological models and rarely so in ESMs (see section "Terrestrial Biosphere Models"). The number of pools varies with model complexity, but a typical approach is to explicitly represent the carbon and nitrogen contents in plant litter material and soil organic matter (SOM), partitioned into various subcomponents, as well as inorganic nutrients in mineral pools, which are directly available for plant uptake (e.g., ${ }^{280,281,282,283,284}$ ). In more recent model formulations, the SOM pool is partitioned among the substrate (available SOM) and the microbial biomass (bacteria, mycorrhiza) that feeds on the substrate ${ }^{285}$, while soil fauna is typically neglected. In some models, extracellular enzymes catalyzing the decomposition reactions are also explicitly represented ${ }^{286,287,288}$. Exchanges between the different pools are typically simulated as the first-order kinetics processes, that account for temperature and soil moisture effects, or as higher order kinetics of the type described by the Michaelis-Menten equation ${ }^{279,289,290}$. A fraction of carbon is lost in the decomposition process as $\mathrm{CO}_{2}$ through heterotrophic respiration. This is controlled by the capacity of the soil microbial biomass to assimilate carbon, defined as Carbon Use Efficiency (CUE). The production of mineral nutrients (e.g., $\mathrm{NO}_{3}{ }^{-}, \mathrm{NH}_{4}^{+}$) is mostly connected to the dynamics of the carbon pools and to the stoichiometry (e.g., carbon-nitrogen ratio) of litter and $\mathrm{SOM}^{291,292}$. Part of nutrients can be lost through deep leakage, erosion, or in the case of nitrogen through denitrification and volatilization, the remaining can be taken up by roots. Plant nutrient uptakes represent an essential component of the vegetation functioning. Nutrient uptake depends on availability of mineral 
nutrients, root density, mycorrhiza symbiosis, plant requirements, but exact mechanisms are not fully understood and their simulation is typically quite simplified ${ }^{284,285,293,294}$. The link with the carbon cycle is evident since soil biogeochemistry regulates the amount of heterotrophically respired $\mathrm{CO}_{2}$, and controls the nutrients accessible to the plants. Nutrient availability affects plant development because of stoichiometric constraints in building plant tissues ${ }^{295}$ and because leaf nitrogen is known to affect photosynthetic capacity ${ }^{296,297,298,299}$. The linkage with plant development offers an important feedback on water and energy exchanges because plant structure (e.g., LAl, vegetation height) modifies boundary conditions at the land surface ${ }^{300}$.

\section{Spatial representation of processes}

The description of how models deal with the water, energy, carbon, and nutrient cycles is weakly related to the spatial dimension of the domain of simulation. In other words, the discussed processes can be used for a domain of $5 \times 5 \mathrm{~m}^{2}$ as well as $100 \times 100 \mathrm{~km}^{2}$, changing only the climate forcing and boundary conditions but largely preserving the same model structure. Although, the process importance and heterogeneity clearly changes with the spatial scale, the conceptualization remains the same and similar approaches have been used at very different scales. A main issue with increasing spatial scale is the difficulty of prescribing appropriate boundary conditions and parameter values with a consequent problem related to the "fallacy of average", i.e., the false assumption that the mean of a nonlinear function of several variables equals the function of the means of these variables ${ }^{301,302}$. Regardless of the scale, a spatial domain has a well-defined topography that needs to be accounted for because it affects climatic inputs such as shortwave and longwave radiation ${ }^{303,304,305,306}$ and rainfall ${ }^{307}$, and because lateral exchanges of water, and nutrients may become significant. Lateral exchanges of energy are believed to be less important but they are essentially unstudied. Distributed ecohydrological models are typically designed to account for lateral exchanges of water ${ }^{307,308}$ and sometime nutrients ${ }^{309,310}$, even when process description is simplified in a comparison to mechanistic solutions ${ }^{266}$. The spatial re-distribution of these resources in the simulated domain allows for an emergence of topographically controlled patterns in vegetation dynamics (e.g., different species composition in southern and northern exposed hillslopes, higher plant density near the stream network, etc.) that can eventually feedback to water and energy exchanges.

Another important aspect of the spatial dimension is represented by competition, establishment and mortality of vegetation. There are few ecohydrological models that aim to reproduce this specific behavior, and they are especially developed to study vegetation patterns in semi-arid environments $311,266,312$. These models typically compromise in the rigorousness of process description in terms of water, energy and carbon dynamics but they explicitly introduce ways, mostly based on stochastic approaches, to simulate seed dispersal, plant establishment and mortality and their interaction with resource availability (water, radiation), which are absent in more complex models. At an even simpler level, models have been proposed to describe self-organized (or self-emergent) vegetation patterns in semi-arid environments using systems of partial differential equations, borrowed from 
dynamic systems theory (e.g., ${ }^{313}$ ). While these studies are quite distant from the representation of the physical processes, they are important to put forward hypotheses on the controls of vegetation spatial organization and regular patterns observed in semi-arid ecosystems $\mathbf{s}^{314,315,316,317,318,319,320}$.

\section{Global scale}

\section{Terrestrial biosphere models}

The request for quantifications of global carbon and water cycles and plant biogeography, especially in the context of understanding consequences of climate change was conducive to the development of models able to simulate vegetation dynamics (Box 2) at the global scale ${ }^{13,321,322,323,324,325}$. These models are indicated with various names: Dynamic Global Vegetation Models (DGVMs), Terrestrial Biosphere Models, Terrestrial Ecosystem Models, and more recently, as vegetation components of Earth System Models (e.g., ${ }^{14,326,327,328,329,330}$ ). Here, the term terrestrial biosphere models is used to refer to this family of models ${ }^{13}$. Typically, terrestrial biosphere models simulate water, energy, carbon, and nutrient cycles using an approach similar to the ecohydrological models described earlier. As a matter of fact, in most cases formulations of carbon dynamics and soil biogeochemistry have been first developed for these models (e.g. ${ }^{15,331,332}$ ) and subsequently adopted into ecohydrological models. A detailed description of terrestrial biosphere models can be found in recent reviews by Prentice et al. $2007^{333}$, Levis $2010^{334}$, Quillet et al. $2010^{335}$, Medlyn et al $2011^{336}$, Fisher et al. $2014^{13}$ and a list of popular models is presented in Table 2 along with a summary of the specifications of each model. The simulated biophysical and biochemical processes are to a large extent similar to the processes described in Section "Plot to catchment scale". We rather emphasize the main differences in comparison to ecohydrological models, related to (i) spatiotemporal scale of application, (ii) model initialization and boundary conditions, and (iii) biogeography and forest demography. We acknowledge that there is a tendency toward convergence in process description between certain ecohydrological and terrestrial biosphere models and in the future the separation may become semantic or mostly a function of the type and scale of application.

A major distinction between ecohydrological and terrestrial biosphere models relies on the different spatiotemporal scales of their applications, and thus the generality that the latter are meant to achieve. Terrestrial biosphere models are not tailored to any particular place or catchment and have to simulate vegetation occurring in the entire Earth surface. In addition, terrestrial biosphere models typically address research questions for longer time scales, when compared to the time horizons of ecohydrological studies, even though exceptions exists and some ecohydrological models have been also developed for long-term analyses ${ }^{263,309}$. This implies that their structure needs to be flexible enough to include various processes and parameterizations and to simulate vegetation response across a large range of climatic conditions and time scales. However, structural and parameterization issues may emerge due to simplified assumptions introduced for the sake of generality and flexibility, as pinpointed recently by Pappas et al. $2013^{337}$. Furthermore, because the spatial representation in terrestrial biosphere models is in the order of several $\mathrm{km}^{2}$, they cannot account 
explicitly for topography. Each computational element may receive a different climate forcing, but, in essence, terrestrial biosphere models are one-dimensional since they do not exchange laterally mass and nutrient fluxes and the effect of local topography in controlling meteorological inputs is not accounted for.

The large spatiotemporal scales of the typical applications carried out with terrestrial biosphere models, requests a different philosophy for assigning the initial conditions (state variables) for the numerical simulations. While for ecohydrological models a initialization period of few years is typically able to bring the examined ecosystem to a representative state (since the vegetation component is often assumed to be in a mature state), longer spin-up periods are required for the initialization of terrestrial biosphere models that simulate short- and long-term soil biogeochemical processes (e.g., soil organic matter and nutrient dynamics). All terrestrial biosphere models account for soil carbon dynamics, many of them for nitrogen (e.g., ${ }^{283,284,338}$ ) and a minor fraction for phosphorous cycle ${ }^{339,340,341}$. It is worth underlying that, although often unrealistic, the assumption of vegetation in equilibrium with the observed environmental conditions (climate, nutrient deposition, weathering rates) is commonly and unavoidably applied for the spin-up of terrestrial biosphere models (e.g., ${ }^{302}$ ). In addition, contrary to the confined spatial extent (i.e., plot and catchment scales) and to the relatively short time-scales (i.e., less than 30 years) of the ecohydrological applications, the applications of terrestrial biosphere models address research questions at the regional or global scales with time horizons of several decades or centuries. Therefore, land use and vegetation cover are often not pre-assigned, as typically done in ecohydrological applications, but are prognostic variables computed by the model. For the same reasons, processes such as forest demography, natural or anthropogenic disturbances, e.g., fire, windthrow, plant diseases, insect attacks, forest management, and plant competition needs to be represented. Feedbacks on vegetation dynamics due to nutrient cycles are also much more relevant at those temporal scales than are for ecohydrological applications, at least in forests ${ }^{342}$. Forest demography in terrestrial biosphere models is similar or identical to the one developed for forest-gap models in forestry research ${ }^{333,58}$. Forest demography can be handled evolving in time an average tree individual ${ }^{344,345,346}$, or by simulating cohorts of individuals with different age classes and size in the stand (e.g., ${ }^{58,302,347,348,349}$ ). This allows, for instance, an explicit representation of early and late successional species and more generally of heterogeneous forests with gaps, uneven stand height and density ${ }^{350,351}$. Disturbances are typically very difficult to simulate mechanistically, even though recently a general framework has been presented ${ }^{352}$, and are mostly simulated removing a certain amount of biomass in a given domain with a given probability of disturbance occurrence. Plant competition is often simulated implicitly assigning "bioclimatic limits" of existence (temperature, soil moisture, or light thresholds for establishment) to specific species or plant functional types, or removing plants that are underperforming from a carbon balance perspective (e.g., ${ }^{344,353}$ ). Mortality is far from being mechanistically simulated ${ }^{354}$ and is typically related to plant negative carbon balances or prescribed with given constant probabilities or as a function of plant age or size $e^{355,356}$. This background mortality is typically summed with the probability of disturbance occurrence. 


\section{Vegetation feedbacks to the climate system}

There are several examples of successful applications of terrestrial biosphere models, which elucidate feedbacks between vegetation dynamics and climate or hydrological cycle at the global and regional scales. One example is represented by the predictions of the fate of the Amazon forest. Early findings suggested potential dieback of the Amazon rainforest in response to projected droughts, with huge implications for the future of Earth's climate ${ }^{357}$. While these extreme projections have been moderated using more refined models, the response of the Amazon forest to a changing climate remains very uncertain (e.g., ${ }^{358,359,360,361,362}$ ). There is a large community effort dedicated to better understand the effect of drought on the Amazon forest (e.g., ${ }^{363,364,365,366}$ ) because current observations and future predictions are suggesting a potential lengthening of the dry intervals and an increase of drought risk ${ }^{367,368}$. At local scales, Amazon deforestation has been demonstrated to affect cloud formation and convective precipitation, because it changes the partition of net radiation into sensible and latent heat, thus affecting boundary layer development. This has the possibility to increase or decrease convective precipitation downwind of the cleared patches as a function of the deforestation extent ${ }^{369,370,371}$.

Another significant example is represented by the observed tree and shrub encroachment at high latitudes. The prognostic nature of vegetation cover in terrestrial biosphere models allows them to simulate shrub encroachment and tree line shifts following, for example, Earth warming. While the exact causes of tree and shrub encroachment are still uncertain ${ }^{372,373}$, shrub presence in previously non-vegetated or poorly vegetated areas of the Arctic has the capacity to modify the hydrology and the energy exchanges between the land and the atmosphere. If shrubs grow taller than typical winter snowpack height, the albedo of the surface is substantially decreased, and the same time the longwave radiation regime is modified ${ }^{374}$. These changes in vegetation have a positive feedback on local and global warming with the potential to further push shrub encroachment or northern tree line expansion ${ }^{375}$.

A final example of important interactions between plants and the water cycle is related to the consequences of increasing atmospheric $\mathrm{CO}_{2}$ concentration. Elevated $\mathrm{CO}_{2}$ concentration has a wellknown direct physiological effect at the leaf level, increasing photosynthesis and reducing stomatal conductance ${ }^{376,377}$. The increased plant productivity associated with elevated $\mathrm{CO}_{2}$ is typically indicated as $\mathrm{CO}_{2}$ fertilization effect (e.g. ${ }^{378}$ ). The integration of this effect from leaf to the global scale is still debated ${ }^{379,380}$ but it has been postulated to have contributed to increase runoff ${ }^{381,382}$ and be largely responsible for the terrestrial carbon sink with direct feedbacks on Earth climate ${ }^{23,383,384}$. While the magnitude of $\mathrm{CO}_{2}$ fertilization at the ecosystem scale and the persistence of the carbon sink in time are still open research areas ${ }^{362,385,386,387}$, it represents one additional example that robust long-term projections of future water cycle cannot be made without accounting for vegetation physiology.

\section{Process up-scaling}




\section{Forcing and boundary conditions}

The models described in the previous sections (plant hydraulic, ecohydrological, and terrestrial biosphere models) are designed to address scientific quesons at different spatiotemporal scales. Plant hydraulic models are typically forced with very detailed meteorological inputs and boundary conditions (e.g., soil type, tree height and diameter, root depth, plant hydraulic traits, etc.) but they are used to simulate a single tree or a specific forest stand and for a relative short period of time (a growing season, few years). It would be in fact unrealistic to simulate each individual tree at the continental scale. At larger spatiotemporal scales, different model types are typically applied. Ecohydrological models are normally employed from the plot to the catchment scale, while terrestrial biosphere models are used from the plot to the global scale. As described previously, terrestrial biosphere models cannot account for fine-scale heterogeneities (e.g., topography, climate) because the spatial resolution at which they usually operate is in the order of several $\mathrm{km}^{2}$. This limitation has been shown to be more relevant than previously thought because the mean response obtained with meteorological forcing and boundary conditions mediated over a large area can be different from the mean of the responses obtained with a detailed treatment of input and boundary conditions ${ }^{302}$. In other words, the non-linear dynamics inherent to hydrological and vegetation processes play a considerable role. In an analogy, the temporal resolution of the model is also very important ${ }^{388,389}$ because coarse temporal resolutions do not allow solving non-linear effects produced by short-term variability in the forcing (e.g., shortwave radiation). In this regard, however, differences among models are less marked, most of the ecohydrological and terrestrial biosphere models are using an hourly or half-hourly time-step for the forcing, at least to solve hydrological and energy dynamics, with few models still using daily or longer scales (e.g., ${ }^{348}$ ). Plant growth, soil biogeochemistry and forest demography processes have typically slower dynamics that can be simulated at the daily time scale or even annually for processes such as forest demography.

\section{Vegetation heterogeneity}

A very important "boundary condition" in any model that deals with vegetation is how the vegetation itself is parameterized. Historically, the existing diversity in species and plant traits (e.g., ${ }^{390}$ ) has been summarized using a given number ( 8-25) of Plant Functional Types (PFTs), that aimed to distinguish climatic zone (e.g., temperate, boreal, tropical), phenology (evergreen, deciduous), and leaf morphology (e.g., needleleaves, broadleaves) of the plant ${ }^{391}$. This approach has been utilized in both ecohydrological and terrestrial biosphere models because it allowed a synthesis of important differences in plant properties as well as phenological behaviour without entering in the details of exact species or intra-species variability. Recently, the PFT approach has been widely criticized and new approaches based on the definition of plant traits and their distributions are becoming progressively popular (e.g., ${ }^{33,392,393,394,395}$ ). These approaches rely on the knowledge of observed distributions of plant properties, "traits", which correspond or can be related to model parameters, such as, maximum photosynthetic capacity, leaf nitrogen content, specific leaf area, root depth and turnover rates, leaf dimension, etc. Beyond the distribution of the values of a given 
plant trait, there are several ecological studies that show a certain degree of coordination between many of these traits ${ }^{396,397,398}$. An illustrative example is the "leaf economics spectrum" that suggest that leaf traits co-vary in a continuum from leaves with a high photosynthetic capacity, nitrogen content, and specific leaf area index and short lifespan typical of fast growing species to the opposite combination typical of slow growing species ${ }^{399,396}$. While cross-correlations have been mostly studied for leaf traits, there is emerging evidence that this holds true for many plant traits ${ }^{400}$ and such information can be transferred to the model parameters. Observed trait distributions and crosscorrelation can be used to create "proxy species", which do not correspond exactly to an observed species but are deemed as realistic within the range of observed natural variation. Models can then use a large number of these "proxy species" to investigate the importance of variability in plant traits in carbon and water dynamics in a given region, or directly use observed distributions of plant traits as input. Note that the latter should be typically weighted for the occurrence of a given species in a specific place or region. Despite the huge amount of biodiversity, forest biomass and productivity are in fact mostly controlled by a limited number of dominant species ${ }^{401}$. A great advantage of the probabilistic approximation of plant trait diversity, based on multivariate distributions of whole-plant trait spectra, rather than on few PFTs or species, is that it allows for a probabilistic assessment of ecosystem response and thus provides a framework for quantifying uncertainties related to vegetation spatiotemporal heterogeneity ${ }^{33,393}$.

\section{Data for model parameterization and confirmation}

Any model, regardless of the scale, needs climate forcings as well as data that can be used for confirmation of model results. Meteorological forcing requirements are similar in most of the models and include air temperature, precipitation, relative humidity, wind speed, atmospheric pressure, $\mathrm{CO}_{2}$ concentration, and shortwave and longwave radiation. Boundary conditions consist of soil properties, such as soil depth, soil texture or soil hydraulic properties (e.g., ${ }^{402,403}$ ), and vegetation properties represented by functional and morphological plant traits (see Section "Vegetation heterogeneity"). In the case of distributed simulations, land-cover, topographic and geologic information is also required. Modelling of soil biogeochemistry and nutrient cycle theoretically needs additional data about initial values of nutrient content, nutrient deposition and primary minerals weathering together with a number of parameters that characterize kinetics and turnover rates of microbial biomass and organic substrate in the soil (e.g. ${ }^{288,404,405}$ ).

There are multiple measurements that can potentially be used in models and that are carried out directly at the plant scale in one or multiple individuals. These are leaf and stem water potential, sapflow, stem diameter changes, leaf turgor, leaf temperature, gas exchange measurements at leaf, root and stem level (Table 3). Additionally, plant hydraulic traits such as stem capacitance and vulnerability curves or biochemical traits such as the ones related to photosynthesis are necessary for accurate parameterization of stomata and plant hydraulic models (e.g., ${ }^{249}$ ). When combined together these measurements do provide a rather complete characterization of plant behaviour, with a notable exception represented by short term carbon allocation dynamics (phloem transport, 
tissue growth and respiration), which are currently very difficult or impossible to measure in the field and mostly limited to leaf growth and point measurements of non-structural carbohydrates repeated few times during a season ${ }^{406}$.

Moving from the plant to the plot/stand scale, measurements are not typically carried out anymore on the individual plants but express an integrated quantity over a given area. This type of measurements includes: (i) energy and mass exchange between the land surface and the atmosphere obtained with flux-tower monitoring systems that employ the eddy covariance technique ${ }^{407,408,409,410,411}$ (ii) soil water content and temperature, and soil respiration at different locations. Measurements of soil water content provide a direct quantification of one of the key variable in the water-vegetation interaction but are difficult to upscale from the sensor level to stand scale due to considerable spatial heterogeneities ${ }^{412,413,414,415}$. Flux-tower measurements are instead an up-scaled quantity but have problems of continuity and interpretation ${ }^{416,417}$. Despite wellrecognized issues ${ }^{418,419}$, flux-tower observations have represented and still represent the major source for validation of ecohydrological and terrestrial biosphere models, since they provide values for variables such as latent and sensible heat, net radiation and mass fluxes of water vapour and carbon. Lysimeters can be also used to measure directly leaching of water and nutrients and the water content variation in soil monoliths, and, therefore, evapotranspiration ${ }^{420,421}$. This measurement is probably the most precise and continuous estimate of evapotranspiration fluxes but it is very expensive to set-up and maintain. Moving from fluxes to stocks, forest inventories represent an important source of information to characterize standing and dead biomass, and plant demography (age, size, and species). When inventories are repeated systematically in time, they also provide information on plant turnover rates, mortality and growth (e.g. ${ }^{422,423}$ ) and they can be used for model testing (e.g., ${ }^{351,302}$ ). Recently, tree ring dendrochronology has been presented as a possibility to test simulations of carbon accumulation as well as the effect of infrequent disturbances ${ }^{424}$. Despite the numerous problems, existing in the scaling from single trees to areal estimates, it represents a potential additional source for model validation.

An alternative way to test models is the recourse to observations carried out during ecological manipulation experiments, e.g., rainfall exclusion and addition, warming, $\mathrm{CO}_{2}$ enrichment (FACE), girdling, and nutrient additions. Such experiments can be used to test whether models can reproduce the effect of treatment at least in terms of observed sensitivity (e.g., ${ }^{365,425,426,427,428}$ ). When models are able to do so without changing their parameterization, this represents an important validation of their predictive skills for conditions different from the current climate. Manipulation experiments have been mostly focused in measuring vegetation productivity, especially in grassland, but other metrics can be also monitored and used for model validation, especially if new experiments will be designed with this additional scope in mind $^{428,429,430}$. In fact, despite their potential importance, manipulation experiments have been seldom used for model testing so far.

Moving to larger spatial scales, direct observations become more challenging and remote sensing as LIDAR and hyperspectral cameras have been recently employed. Observational devices can be 
placed over land or aircraft platforms or on satellites ${ }^{431,432}$. Remote sensing observations can be carried out with optic or radar sensors and are mostly used to measure vegetation reflectivity indices, carbon stocks, and soil moisture. Carbon stocks are typically observed with radar sensors and at the regional scale (e.g., ${ }^{433,434}$ ). Optic observations in multiple spectral bands are typically mapping the entire Earth and they are used to derive vegetation indices as the Enhanced Vegetation Index (EVI), the Normalized Difference Vegetation Index (NDVI), or chlorophyll fluorescence ${ }^{435,436}$. Signals in multiple bands can be also processed and converted into variables such as LAI, carbon assimilation $^{437,438}$ or nutrient contents of the leaves ${ }^{439}$, although the reliability of these estimates is still uncertain (e.g., ${ }^{40,441}$ ). A few remote sensing products are also available for near surface soil water content (e.g., ${ }^{442}$ ), as well as promising results in this direction are expected from campaigns as Soil Moisture Active Passive (SMAP) $)^{443}$. Finally, anomalies of atmospheric $\mathrm{CO}_{2}$ concentration are an important source of information to estimate the net carbon uptake or release over very large areas and at the seasonal and annual time-scale ${ }^{384,444}$, and they may become even more so in the future $e^{445}$.

\section{Conclusion}

The examined literature suggests that approaches to simulate the intertwined dynamics of water, energy, carbon, and nutrients cycles are becoming widely available and that a number of models of different complexity has been presented to address problems at various scales. While the combination of hydrology and ecology can be considered a reality, additional efforts need to be devoted to integrate solutions developed for different scales.

The issue of scales is not merely an operational one related to finding better parameterizations but requires innovative approaches to preserve key physical and ecological mechanisms operating locally as well as heterogeneities into larger-scale applications. We do not mean that the entire complexity of plant-hydraulic or detailed biogeochemistry models should be retained into ecohydrological or terrestrial biosphere models but there is a wide margin to better use insights gained at local scales into watershed, regional and global applications $\left(\mathrm{see}^{125}\right)$. For instance, models simulating mechanistically plant hydraulic and carbon dynamics are still rare and confined to specialized studies ${ }^{202,208,209,214,}$, but they have the potential to improve considerably representation of fundamental aspects such as plant growth, response to elevated $\mathrm{CO}_{2}$, response to severe droughts or pathogen attacks, and ultimately plant mortality. These are subjects where we still have gaps in process understating and where a well-structured combination of modelling and observations is likely to provide insights well beyond model improvements, potentially increasing fundamental knowledge of plant-water interactions. Modelling plant mortality has been regarded as one of the great scientific challenge ${ }^{446}$ and surely it is, but we should not forget that current models still struggle to simulate correctly the response to water limitations ${ }^{447}$ and have limited flexibility to accommodate diverging response across species or within a landscape ${ }^{33,302}$.

Most of the processes underlying plant-water interactions are highly non-linear, this implies that averaging significant heterogeneities in space and time may lead to considerable biases. While the importance of solving ecohydrological processes at the sub-daily temporal scales is progressively 
recognized $388,389,448$ and implemented in most of the models, the relevance of being spatially explicit has been less emphasized in literature ${ }^{302}$. Few studies presented process-based simulations accounting explicitly for topographic attributes and lateral water and mass exchanges ${ }^{300,307,308,449}$. Applications at regional or continental scale of ecohydrological models or the introduction of topography in terrestrial biosphere models will represent possible solutions. These solutions bring along operational issues related to computational resources and accurate model parameterizations. Large spatial and long temporal scales pose great challenges for model initialization and validation, since current available data are typically inadequate when compared to the diversity of model outputs. A better integration of data from multiple platforms and scales and especially of remote sensing estimates is thus essential for improving distributed and/or continental scale models. A more rigorous treatment of uncertainty with stochastic analyses and probabilistic predictions should also represent an important avenue for the future, since many model parameters (e.g., plant and microbial traits) are unlikely to be known with a high accuracy everywhere and vary, not only in space but also in time ${ }^{33}$. Studies and modelling of plant-water interactions have seen great advancements in the past years but current shortcomings and the challenges pose by environmental changes and preservation of water resources and ecosystem services are suggesting that exciting times are still ahead.

Box 1: Plant physiology: definitions

Definitions of plant physiological terms are provided to guide readers. Xylem refers to non-living vascular conduits of plants that transport water from the roots to the leaves (Fig. 4). Phloem refers to vascular conduits that transport sugars produced by photosynthesis to other tissues in the plant (Fig. 4). Water potential is the potential energy of water per unit volume relative to pure water in reference conditions. Water potential quantifies the tendency of water to move from one area to another due to osmosis, mechanical pressure, or matrix effects such as capillary action. Cavitation is the processes that leads to formation and growth of vapour bubbles in a liquid, in the case of plants it occurs within the xylem. Non-structural carbohydrates (NSC) are the free, low molecular weight sugars (glucose, fructose and sucrose) plus starch, readily available for transport and plant metabolism. Abscisic acid ( $A B A$ ) is a plant hormone involved in many plant processes, including stomatal closure, bud dormancy, leaf abscission. Aquaporins are integral membrane proteins that form pores in the membrane of biological cells and allow for the selective passage of water. Cytoplasm is the portion of the cell that is enclosed within the cell membrane and is composed by organelles and a gel-like substance. Suberin is a waterproofing waxy substance present in the cell walls of certain plant tissue.

\section{Box 2: Vegetation dynamics}

The term "vegetation dynamics" when referred to models may have different meanings according to the context where it is used. In a large fraction of terrestrial biosphere model literature, vegetation 
dynamics is used for referring to models where the vegetation type (e.g., PFT or species) is prognostic in space and time. In other words, vegetation dynamics are related to processes such plant establishment and mortality, forest demography, disturbances that may modify the amount and type of vegetation occurrence. In ecohydrological model literature, vegetation dynamics typically refer to model that simulate prognostically vegetation attributes such as leaf area index, root density, carbon allocation or more generally a number of carbon pools. Finally, in some context vegetation dynamics may simply refer to a model that is simulating the temporal evolution of processes connected to vegetation but not directly linked to the plant structure such as photosynthesis, respiration or stomatal conductance. For sake of generality, in the article we use the broadest definition of vegetation dynamics that includes both fast and slow processes through which models simulate temporal evolution of plant properties.

Notes

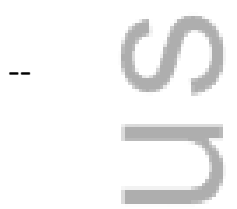

References

[1] Oki T. and Kanae S. Global hydrological cycles and world water resources. Science 2006, 313: 1068 1072, doi:10.1126/science.1128845.

[2] Katul GG, Oren R, Manzoni S, Higgins C, and Parlange MB. Evapotranspiration: A process driving mass transport and energy exchange in the soil-plant-atmosphere-climate system. Reviews of Geophysics 2012, 50(3):RG3002.

[3] Schlesinger WH and Jasechko. S. Transpiration in the global water cycle. Agricultural and Forest Meteorology 2014, 189-190:115 117,http://dx.doi.org/10.1016/j.agrformet.2014.01.011.

[4] Wild M, Folini D, Hakuba MZ, Schär C, Seneviratne SI, Kato S, Rutan D, Ammann C, Wood EF, and König-Langlo $\mathrm{G}$. The energy balance over land and oceans: an assessment based on direct observations and CMIP5 climate models. Climate Dynamics 2015, 44(11-12):3393 3429.

[5] Eagleson PS. Climate, soil, and vegetation 1. Introduction to water balance dynamics. Water Resources Research 1978, 14(5):705 712.

[6] Bonan GB. Ecological Climatology. Cambridge University Press, 2008.

[7] Berry JA, Beerling DJ, and Franks PJ. Stomata: key players in the earth system past and present. Current Opinion in Plant Biology 2010, 13(3):232 239. 
[8] Nobel PS. Physicochemical and Environmental Plant Physiology . Elsevier Academic Press, 2009.

[9] Brown AD. Microbial water stress physiology, principles and perspectives . John Wiley and Sons, Chichester, UK., 1990.

[10] Anderson SP, von Blanckenburg F, and White AF. Physical and chemical controls on the critical zone. Elements, 3(5):315 319, 2007.

[11] McMahon TA, Peel MC, Lowe L, Srikanthan R, and McVicar TR. Estimating actual, potential, reference crop and pan evaporation using standard meteorological data: a pragmatic synthesis. Hydrol. Earth Syst. Sci. 2013, 17:1331-1363 doi:10.5194/hess-17-1331-2013.

2] Gerten D, Schaphoff S, Haberlandt U, Lucht W, and Sitch S. Terrestrial vegetation and water balance-hydrological evaluation of a dynamic global vegetation model. Journal of Hydrology 2004, 286:249 270 .

[13] Fisher, J. B., Huntzinger, D. N., Schwalm, C. R. and Sitch, S. Modeling the Terrestrial Biosphere. Annu. Rev. Environ. Resour. 2014, doi:10.1146/annurev-environ-012913-093456.

[14] Sellers PJ, Mintz Y, Sud YC, and Dalcher. A. A simple biosphere model (SiB) for use within general circulation models. Journal of the Atmospheric Sciences 1986, 43(6):505 531.

[15] Sellers PJ, Randall DA, Collatz GJ, Berry JA, Field CB, Dazlich CA, Zhang C, Collelo D., and Bounoua L. A revised land surface parameterization (SiB2) for atmospheric GCMs. 1. Model formulation. Journal of Climate 1996, 9(4):674 705.

[16] Sellers PJ, Dickinson RE, Randall DA, Betts AK, Hall FG, Berry JA, Collatz GJ, Denning AS, Mooney HA, Nobre CA, Sato N, Field CB, and Henderson-Sellers A. Modeling the exchanges of energy, water and carbon between continents and the atmosphere. Science 1997, 275:502 509.

[17] Rodriguez-Iturbe I. Ecohydrology: A hydrological perspective of climate-soil-vegetation dynamics. Water Resources Research 2000, 36(1):3 9.

[18] Porporato A, Laio F, Ridol L, and Rodriguez-Iturbe I Plants in water-controlled ecosystems: active role in hydrologic processes and response to water stress III. Vegetation water stress. Advances in Water Resources 2001, 24:725 744.

[19] Eagleson PS. Ecohydrology: Darwinian Expression of Vegetation Form and Function . Cambridge University Press, Cambridge, U.K., 2002.

[20] Rodriguez-Iturbe I and Porporato A. Ecohydrology of Water-Controlled Ecosystems . Cambridge University Press 2004.

[21] Bond B. Hydrology and ecology meet-and the meeting is good. Hydrological Processes 2003, 17: 2087 2089, doi:10.1002/hyp.5133. 
[22] Friedlingstein P, Cox PM, Betts RA, Bopp L, VonBloh W, Brovkin V, Cadule P, Doney S, Eby M, Fung I, et al. Climate-carbon cycle feedback analysis: Results from the C4MIP model intercomparison. Journal of Climate 2006, 19(14):3337 3353.

[23] Arora VK, Boer GJ, Friedlingstein P, Eby M, Jones CD, Christian JR, Bonan LBG, Brovkin V, Cadule P, Hajima T, et al. Carbon-concentration and carbon-climate feedbacks in CMIP5 Earth System models. J. Climate 2013, 26:5289 5314, doi:10.1175/JCLI-D-12-00494.1.

[24] Friedlingstein P., Meinshausen $M$, Arora VK, Jones CD, Anav A, Liddicoat SK, and Knutti R. Uncertainties in CMIP5 climate projections due to carbon cycle feedbacks. Journal of Climate, 2014, 27:511526.

\section{$=$}

[25] Fatichi S, Zeeman MJ, Fuhrer J, and Burlando P. Ecohydrological effects of management on subalpine grasslands: from local to catchment scale. Water Resources Research 2014, 50, 148-164 doi:10.1002/2013WR014535.

[26] Mooney H, Larigauderie A, Cesario M, Elmquist T, Hoegh-Guldberg O, Lavorel S, Mace GM, Palmer M, Scholes R, and Yahara T. Biodiversity, climate change, and ecosystem services. Current Opinion in Environmental Sustainability 2009, 1:46 54. doi:10.1016/j.cosust.2009.07.006.

[27] Istanbulluoglu E and Bras RL. Vegetation-modulated landscape evolution: Effects of vegetation on landscape processes, drainage density, and topography. Journal of Geophysical Research 2005, 110(F02012). doi:10.1029/2004JF000249.

[28] Lobell DB, Schlenker W, and Costa-Roberts J. Climate trends and global crop production since 1980. Science 2011, 333:616 620. doi:10.1126/science.1204531.

[29] Dai A, Trenberth KE, Qian T. A global dataset of Palmer drought severity index for 1870-2002: Relationship with soil moisture and effects of surface warming. J. Hydrometeorol. 2004 5:1117-1130.

[30] Sheffield J, Wood EF, Roderick ML. Little change in global drought over the past 60 years. Nature, 2012 491:435-438, doi:10.1038/nature11575.

[31] Fu Q, Feng S. Responses of terrestrial aridity to global warming. J. Geophys. Res. Atmos., 2014, 119:7863-7875, doi:10.1002/2014JD021608.

[32] Roderick ML, Greve P, and Farquhar GD. On the assessment of aridity with changes in atmospheric $\mathrm{CO}_{2}$. Water Resources Research, 2015, 2(51):5450-5463, doi:10.1002/2015WR017031.

[33] Pappas C, Fatichi S, and Burlando P. Modeling terrestrial carbon and water dynamics across climatic gradients: does plant diversity matter? - New Phytologist, 2015, doi: 10.1111/nph.13590

[34] Inauen N, Körner C, Hiltbrunner E. Hydrological consequences of declining land use and elevated $\mathrm{CO}_{2}$ in alpine grassland. Journal of Ecology, 2013 101:86-96, doi: 10.1111/1365-2745.12029. 
[35] Gough CM, Hardiman BS, Nave LE, Bohrer G, Maurer KD, Vogel CS, Nadelhoffer KJ and Curtis PS. Sustained carbon uptake and storage following moderate disturbance in a great lakes forest. Ecological Applications, 2013 23(5):1202-1215.

[36] Biederman JA, Harpold AA, Gochis DJ, Ewers BE, Reed DE, Papuga SA, and Brooks PD. Increased evaporation following widespread tree mortality limits streamflow response. Water Resources Research, 2014, 50:5395-5409 doi:10.1002/2013WR014994.

[37] Abdelnour A, Stieglitz M, Pan F, and McKane R. Catchment hydrological responses to forest harvest amount and spatial pattern. Water Resources Research 2011, 47(W09521). doi:10.1029/2010WR010165.

[38] Brown AE, Zhang L, McMahon TA, Western AW, and Vertessy RA. A review of paired catchment studies for determining changes in water yield resulting from alterations in vegetation. Journal of Hydrology, 2005, 310:28-61 doi:10.1016/j.jhydrol.2004.12.010.

[39] Guardiola-Claramonte M, Troch PA, Breshears DD, Huxman TE, Switanek MB, Durcik M, and Cobb NS. Decreased streamflow in semi-arid basins following drought-induced tree die-off: $A$ counter-intuitive and indirect climate impact on hydrology. Journal of Hydrology, 2011, 406(34):225-233.

[40] Pearson RG, Phillips SJ, Loranty MM, Beck PSA, Damoulas T, Knight SJ, Goetz SJ. Shifts in Arctic vegetation and associated feedbacks under climate change. Nature Climate Change, 2013, 3:673677.

[41] Matheny A, Bohrer G, Vogel CS, Morin TH, He L, Frasson RPM, Mirfenderesgi G, Schäfer KVR, Gough CM, Ivanov VY, Curtis PS. Species-specific transpiration responses to intermediate disturbance in a northern hardwood forest. Journal of Geophysical Research 2014, 119:2292-2311.

[42] Pomeroy JW, Marks DM, Link T, Ellis C, Hardy J, Rowlands A, and Granger R. The impact of coniferous forest temperature on incoming longwave radiation to melting snow. Hydrological Processes 2009, 23:2513 2525.

[43] Ellis CR, Pomeroy JW, Brown T, and MacDonald J. Simulation of snow accumulation and melt in needleleaf forest environments. Hydrol. Earth Syst. Sci. 2010, 14:925 940. doi:10.5194/hess-14-9252010.

[44] Broxton PD, Harpold AA, Biederman JA, Troch PA, Molotch NP, and Brooks PD. Quantifying the effects of vegetation structure on snow accumulation and ablation in mixed-conifer forests. Ecohydrology 2015, Early view: , 2015. doi:10.1002/eco.1565.

[45] Bohrer G, Katul GG, Walko RL, and Avissar R. Exploring the effects of microscale structural heterogeneity of forest canopies using large-eddy simulations. Boundary-Layer Meteorology 2009, 132:351 382. doi:10.1007/s10546-009-9404-4. 
[46] Mahat V, Tarboton DG, and Molotch NP. Testing above- and below-canopy representations of turbulent fluxes in an energy balance snowmelt model. Water Resources Research, 49:1107 1122, 2013. doi:10.1002/wrcr.20073.

[47] Lundquist JD, Dickerson-Lange SE, Lutz JA, and Cristea NC. Lower forest density enhances snow retention in regions with warmer winters: A global framework developed from plot-scale observations and modelling. Water Resources Research, 49(10): 6356 6370, 2013. doi:10.1002/wrcr.20504.

[48] Duarte CM, Middelburg JJ, and Caraco N. Major role of marine vegetation on the oceanic carbon cycle. Biogeosciences 2005 2:1 8 .

[49] Katul GG, Poggi D, and Ridolfi L. A low resistance model for assessing the impact of vegetation on flood routing mechanics. Water Resources Research 2011, 47(W08533). doi:10.1029/2010WR010278.

[50] Kim J, Ivanov VY, and Katopodes ND. Hydraulic resistance to overland flow on surfaces with partially submerged vegetation. Water Resources Research 2012, 48(W10540). doi:10.1029/2012WR012047.

[51] Marjoribanks TI, Hardy RJ, and Lane SN. The hydraulic description of vegetated river channels: the weaknesses of existing formulations and emerging alternatives. WIREs Water 2014, 1:549 560. doi: $10.1002 /$ wat2.1044.

[52] Rodriquez-Iturbe I, D'Odorico P, Porporato A, and Ridolfi L. On the spatial and temporal links between vegetation, climate, and soil moisture. Water Resources Research, 1999, 35:3709-3722.

[53] Ridolfi L, D'Odorico P, Porporato A, Rodriguez-Iturbe I. Duration and frequency of water stress in vegetation: An analytical model. Water Resources Research, 2000, 36(8):2297-2307.

[54] Guswa AJ. The influence of climate on root depth: A carbon cost-benefit analysis. Water Resources Research, 2008, 44:W02427, doi:10.1029/2007WR006384.

[55] Thompson SE, Harman CJ, Troch PA, Brooks PD, and Sivapalan M. Spatial scale dependence of ecohydrologically mediated water balance partitioning: A synthesis framework for catchment ecohydrology. Water Resources Research, 2011, 47:W00J03, doi:10.1029/2010WR009998.

[56] Manzoni S, Vico G, Katul GG, Palmroth S, Jackson RB, and Porporato A. Hydraulic limits on maximum plant transpiration and the emergence of the safety-efficiency trade-off. New Phytologist, 2013, 198:169-178, doi: 10.1111/nph.12126.

[57] Manzoni S, Vico G, Katul GG, Palmroth S, Porporato A. Optimal plant water use strategies under stochastic rainfall. Water Resources Research, 2014, 50:5379-5394, 2014. doi:10.1002/2014WR015375. 
[58] Bugmann H. A review of forest gap models. Clim. Change 2001, 51:259 305.

[59] Weiskittel AR, Hann DW, Kershaw JA, Vanclay JK. Forest Growth and Yield Modeling. WileyBlackwell, Oxford, UK. 2011

[60] Tyree MT. The ascent of water. Nature 2003, 423:923.

[61] Campbell GS and Norman JM. An Introduction to Environmental Biophysics. Springer-Verlag New York, Inc., 1998.

[62] Zimmermann MH. Transport in the phloem. Annu. Rev. Plant. Physiol. 1960, 11:167 190.

[63] Pickard WF. The ascent of sap in plants. Prog. Biophys. Mol. Biol. 1981, 37:181 229.

[64] Holbrook NM and Zwieniecki MA. Vascular Transport in Plants., Elsevier, Amsterdam 2005.

[65] Jensen KH, Berg-Sørensen K, Friis SMM, and Bohr T. Analytic solutions and universal properties of sugar loading models in Münch phloem flow. J. Theor. Biol. 2012, 304:286 296.

[66] Stroock AD, Pagay VV, Zwieniecki MA, and Holbrook NM. The physicochemical hydrodynamics of vascular plants. Annual Review of Fluid Mechanics 2014, 46:615 642.

[67] Taiz L, Zeiger E. Plant Physiology. Sinauer Associates Inc, Sunderland, Massachusetts, 2006.

[68] von Caemmerer S and Farquhar GD. Some relationships between the biochemistry of photosynthesis and the gas exchange of leaves. Planta 1981, 153:376 387.

[69] Evans JR, Kaldenho R, Genty B, and Terashima I. Resistances along the $\mathrm{CO}_{2}$ diffusion pathway inside leaves. Journal of Experimental Botany 2009, 60(8):2235 2248. doi:10.1093/jxb/erp117.

[70] Bernacchi CJ, Bagley JE, Serbin SP, Ruiz-Vera UM, Rosenthal DM, and Van-Loocke A. Modelling C3 photosynthesis from the chloroplast to the ecosystem. Plant, Cell \& Environment 2013, (36):1641-1657. doi: 10.1111/pce.12118.

[71] Sack L and Scoffoni C. Leaf venation: structure, function, development, evolution, ecology and applications in the past, present and future. New Phytologist 2013, 198:983 1000. doi:10.1111/nph.12253.

[72] Franks PJ and Beerling DJ. Maximum leaf conductance driven by $\mathrm{CO} 2$ effects on stomatal size and density over geologic time. Proceedings of the National Academy of Sciences USA, 2009, 106(25):10343-10347.

[73] Assouline S, Or D. Plant water use efficiency over geological time -evolution of leaf stomata configurations affecting plant gas exchange. PLoS One, 2013, 8(7):e67757, doi:10.1371/journal.pone.0067757. 
[74] Cochard H, Nardini A, and Coll L. Hydraulic architecture of leaf blades: where is the main resistance? Plant, Cell \& Environment 2004, 27:1257 1267. doi: 10.1111/j.1365-3040.2004.01233.x.

[75] Sack L and Holbrook NM. Leaf hydraulics. Annual Review of Plant Biology 2006, 57:361 381.

[76] Brodribb TJ, Field TS, and Jordan GJ. Leaf maximum photosynthetic rate and venation are linked by hydraulics. Plant Physiology 2007, 144:1890 1898.

[77] Hetherington AM and Woodward FI. The role of stomata in sensing and driving environmental change. Nature 2003, 424:901 908.

[78] Jarvis PG. The interpretation of the variances in leaf water potential and stomatal conductance found in canopies in the field. Philosophical Transactions of the Royal Society of London, Series $B$ 1976, 273:593 610 .

[79] Monteith JL. A reinterpretation of stomatal responses to humidity. Plant, Cell \& Environment 1995, 18:357-364.

[80] Assmann SM. The cellular basis of guard cell sensing to rising $\mathrm{CO}_{2}$. Plant, Cell and Environment 1999, 22:629 637.

[81] Merilo E, Joesaar I, Brosché $M$, and Kollist $H$. To open or to close: species-specific stomatal responses to simultaneously applied opposing environmental factors. New Phytologist 2014, 202: 499 508. doi: $10.1111 /$ nph.12667.

[82] Buckley TN and Schymanski SJ. Stomatal optimisation in relation to atmospheric $\mathrm{CO}_{2}$. New Phytologist 2014, 201:372 377. doi: 10.1111/nph.12552.

[83] Fischer RA. The relationship of stomatal aperture and guard-cell turgor pressure in Vicia faba. Journal of Experimental Botany 1973, 24(79):387 399.

[84] Buckley TN, Mott KA, and Farquhar GD. A hydromechanical and biochemical model of stomatal conductance. Plant, Cell \& Environment 2003, 26:1767 1785.

[85] Buckley TN. The control of stomata by water balance. New Phytologist 2005, 169:275 292. doi: 10.1111/j.1469-8137.2005.01543.x.

[86] Comstock JP. Hydraulic and chemical signalling in the control of stomatal conductance and transpiration. J. Exp. Bot 2002, 53:195 200.

[87] Brodribb TJ and Holbrook NM. Stomatal closure during leaf dehydration, correlation with other leaf physiological traits. Plant Physiology 2003, 132:2166 2173. 
[88] Brodribb TJ and Holbrook NM. Stomatal protection against hydraulic failure: a comparison of coexisting ferns and angiosperms. New Phytologist 2004, 162:663 670. doi: 10.1111/j.14698137.2004.01060.x.

[89] Guyot G, Scoffoni C, and Sack L. Combined impacts of irradiance and dehydration on leaf hydraulic conductance: insights into vulnerability and stomatal control. Plant, Cell \& Environment 2012, 35:857 871. doi: 10.1111/j.1365-3040.2011.02458.x.

[90] Pantin F, Monnet F, Jannaud D, Costa JM, Renaud J, Muller B, Simonneau T, and Genty B. The dual effect of abscisic acid on stomata. New Phytologist 2013, 197:65 72. doi: 10.1111/nph.12013.

[91] Zeiger E. The biology of stomatal guard cells. Ann. Rev. Plant Physiol. 1983, 34:441 475.

[92] Talbott LD and Zeiger E. The role of sucrose in guard cell osmoregulation. Journal of Experimental Botany 1998, 49:329 337.

[93] Roelfsema MRG and Hedrich R. In the light of stomatal opening: new insights into the watergate. New Phytologist 2005, 167:665 691. doi:10.1111/j.1469-8137.2005.01460.x.

[94] Wilkinson S and Davies WJ. ABA-based chemical signalling: the co-ordination of responses to stress in plants. Plant, Cell and Environment 2002, 25:195 210.

[95] Brodribb TJ and McAdam SAM. Abscisic acid mediates a divergence in the drought response of two conifers. Plant Physiology 2013, 162:1370 1377.

[96] Dodd IC. Abscisic acid and stomatal closure: a hydraulic conductance conundrum? New Phytologist 2013, 197:6 8. doi: 10.1111/nph.12052.

[97] Franks PJ and Farquhar GD. The effect of exogenous abscisic acid on stomatal development, stomatal mechanics, and leaf gas exchange in Tradescantia Virginiana. Plant Physiology 2001, 125:935 942.

[98] Brodribb TJ and McAdam SAM. Passive origins of stomatal control in vascular plants. Science 2011, 331:582 585. doi:10.1126/science.1197985.

[99] Dewar RC. Interpretation of an empirical model for stomatal conductance in terms of guard cell function. Plant, Cell \& Environment 1995, 18:365 372.

[100] Dewar RC. The Ball-Berry-Leuning and Tardieu-Davies stomatal models: synthesis and extension within a spatially aggregated picture of guard cell function. Plant, Cell \& Environment 2002, 25:1383 1398.

[101] Gao Q, Xhao P, Zeng X, Cai X, and Shen W. A model of stomatal conductance to quantify the relationship between leaf transpiration, microclimate, and soil water stress. Plant, Cell and Environment 2002, 25:1373 1381. 
[102] Franks PJ. Stomatal control and hydraulic conductance, with special reference to tall trees. Tree Physiology 2004, 24:865 878.

[103] Franks PJ, Drake PL, and Froend RH. Anisohydric but isohydrodynamic: seasonally constant plant water potential gradient explained by a stomatal control mechanism incorporating variable plant hydraulic conductance. Plant, Cell \& Environment 2007, 30:19-30. doi: 10.1111/j.13653040.2006.01600.x.

[104] Peak D and Mott KA. A new, vapour-phase mechanism for stomatal responses to humidity and temperature. Plant, Cell and Environment 2011, 34:162 178. doi: 10.1111/j.1365-3040.2010.02234.x.

[105] de Boer HJ, Eppinga MB, Wassen MJ, and Dekker SC. A critical transition in leaf evolution facilitated the Cretaceous angiosperm revolution. Nature Communications 2012, 3(1221). doi:10.1038/ncomms2217.

[106] Mott KA and Peak D. Testing a vapour-phase model of stomatal responses to humidity. Plant, Cell and Environment 2013, 36:936-944.

[107] Tuzet A, Perrier A, and Leuning R. A coupled model of stomatal conductance, photosynthesis and transpiration. Plant, Cell \& Environment 2003, 26:1097 1116.

[108] Damour G, Simonneau T, Cochard H, and Urban L. An overview of models of stomatal conductance at the leaf level. Plant, Cell \& Environment 2010, 33:1419 1438. doi: 10.1111/j.13653040.2010.02181.x.

[109] Tardieu F and Davies WJ. Integration of hydraulic and chemical signalling in the control of stomatal conductance and water status of droughted plants. Plant, Cell \& Environment 1993, 16:341 349.

[110] Tardieu F and Simonneau T. Variability among species of stomatal control under fluctuating soil water status and evaporative demand: modelling isohydric and anisohydric behaviours. Journal of Experimental Botany 1998, 49:419 432.

[111] Buckley TN and Mott KA. Modelling stomatal conductance in response to environmental factors. Plant, Cell and Environment, 2013, 36:1691-1699, doi: 10.1111/pce.12140.

[112] Ball JT, Woodrow IE, and Berry JA. A model predicting stomatal conductance and its contribution to the control of photosynthesis under different environmental conditions. In Biggins, editor, Progress in photosynthesis research 1987, pages 221 224. Martinus Nijho, Netherlands.

[113] Leuning R. Modelling stomatal behaviour and photosynthesis of Eucalyptus Grandis. Australian Journal of Plant Physiology, 1990, 17:159 175. 
[114] Leuning R. A critical appraisal of a combined stomatal- photosynthesis model for C3 plants. Plant, Cell \& Environment 1995, 18:357 364.

[115] Farquhar GD, von Caemmerer S, and Berry JA. A biochemical model of photosynthetic $\mathrm{CO}_{2}$ assimilation in leaves of C3 species. Planta 1980, 149:78 90.

[116] Collatz GJ, Ball JT, Grivet C, and Berry JA. Physiological and environmental regulation of stomatal conductance, photosynthesis and transpiration-a model that includes a laminar boundarylayer. Agricultural and Forest Meteorology 1991, 54:107 136.

[117] Collatz GJ, Ribas-Carbo M, and Berry JA. Coupled photosynthesis-stomatal conductance model for leaves of C4 plants. Australian Journal of Plant Physiology 1992, 19:519 538.

[118] Wang YP and Leuning R. A two-leaf model for canopy conductance, photosynthesis and partitioning of available energy I: Model description and comparison with a multi-layered model. Agricultural and Forest Meteorology 1998, 91:89 111.

[119] Bonan GB, Lawrence PJ, Oleson KW, Levis S, Jung M, Reichstein M, Lawrence DM, and Swenson SC. Improving canopy processes in the Community Land Model version 4 (CLM4) using global flux fields empirically inferred from FLUXNET data. Journal of Geophysical Research 2011, 116(G02014). doi:10.1029/2010JG001593.

[120] Medlyn BE, Duursma RA, De Kauwe MG, and Prentice IC. The optimal stomatal response to atmospheric $\mathrm{CO}_{2}$ concentration: Alternative solutions, alternative interpretations. Agricultural and Forest Meteorology 2013, 182 - 183:200 203.

[121] Lin ZS, Medlyn BE, Duursma RA, Prentice IC, Wang H, Baig S, Eamus D, de Dios VR, Mitchell P, Ellsworth DS, et al. Optimal stomatal behaviour around the world. Nature Climate Change 2015, 5:459-464.

[122] Katul G, Manzoni S, Palmroth S, and Oren R. A stomatal optimization theory to describe the effects of atmospheric $\mathrm{CO}_{2}$ on leaf photosynthesis and transpiration. Annals of Botany 2010, 105:431 442.

[123] Medlyn BE, Duursma RA, Eamus D, Ellsworth DS, Prentice IC, Barto CVM, Crous KY, De Angelis $P$, Freeman $M C$, and Wingate L. Reconciling the optimal and empirical approaches to modelling stomatal conductance. Glob. Change Biol 2011, 17:2134 2144.

[124] Manzoni S, Vico G, Palmroth S, Porporato A, and Katul G. Optimization of stomatal conductance for maximum carbon gain under dynamic soil moisture. Advances in Water Resources 2013, 62:90 105 . 
[125] Bonan GB, Williams M, Fisher RA, and Oleson KW. Modeling stomatal conductance in the earth system: linking leaf water-use efficiency and water transport along the soil-plant-atmosphere continuum. Geosci. Model Dev. 2014, 7:2193-2222. doi:10.5194/gmd-7-2193-2014.

[126] Egea G, Verhoef A, and Vidale PL. Towards an improved and more flexible representation of water stress in coupled photosynthesis-stomatal conductance models. Agricultural and Forest Meteorology 2011, 151:1370 1384.

[127] Zhou S, Duursma RA, Medlyn BE, Kelly JWG, and Prentice IC. How should we model plant responses to drought? An analysis of stomatal and non-stomatal responses to water stress. Agricultural and Forest Meteorology 2013, 182-183:204 214.

[128] Manzoni S, Vico G, Katul G, Fay PA, Polley W, Palmroth S, and Porporato A. Optimizing stomatal conductance for maximum carbon gain under water stress: a meta-analysis across plant functional types and climates. Functional Ecology 2011, 25:456 467. doi: 10.1111/j.13652435.2010.01822.x.

[129] Clode PL, Kilburn MR, Jones DL, Stockdale EA, Cliff III JB, Herrmann AM, and Murphy DV. In situ mapping of nutrient uptake in the rhizosphere using nanoscale secondary ion mass spectrometry. Plant Physiology 2009, 151:1751 1757.

[130] Jones DL, Nguyen C, and Finlay RD. Carbon flow in the rhizosphere: carbon trading at the soilroot interface. Plant and Soil 2009, 321:5 33. doi:10.1007/s11104-009-9925-0.

[131] Hinsinger P, Bengough AG, Vetterlein D, and Young IM. Rhizosphere: biophysics, biogeochemistry and ecological relevance. Plant and Soil 2009, 321:117 152. doi:10.1007/s11104-0089885-9.

[132] Carminati A, Moradi AB, Vetterlein D, Vontobel P, Lehmann E, Weller U, Vogel HJ, and Oswald SE. Dynamics of soil water content in the rhizosphere. Plant and Soil 2010, 332:163 176. doi:10.1007/s11104-010-0283-8.

[133] Jackson RB, Mooney HA, and Schulze ED. A global budget for net root biomass, surface area, and nutrient contents. Proc. Natl. Acad. Sci. USA 1997, 94:7362 7366.

[134] McCormack ML, Dickie IA, Eissenstat DM, Fahey TJ, Fernandez CW, Guo D, Helmisaari HS, Hobbie EA, Iversen CM, Jackson RB, et al. Redefining fine roots improves understanding of belowground contributions to terrestrial biosphere processes. New Phytologist 2015, -. doi: 10.1111/nph.13363

[135] Boyer JS. Water transport. Annu. Rev. Plant Physiol. 1985, 36:473 516. 
[136] Nadezhdina N, David TS, David JS, Ferreira MI, Dohnal M, Tesar M, Gartner K, Leitgeb E, Nadezhdin V, Cermak J, et al. Trees never rest: the multiple facets of hydraulic redistribution. Ecohydrology 2010, 3:431 444. doi:10.1002/eco.148.

[137] Goldsmith GR. Changing directions: the atmosphere-plant-soil continuum. New Phytologist 2013, 199:4 6, 2013. doi: 10.1111/nph.12332.

[138] Neumann RB and Cardon ZG. The magnitude of hydraulic redistribution by plant roots: a review and synthesis of empirical and modeling studies. New Phytologist 2012 194:337-352. doi: 10.1111/j.1469-8137.2012.04088.x.

[139] Gardner WR. Relation of root distribution to water uptake and availability. Agronomy Journal $1964,56: 4145$.

[140] Sperry JS, Adler FR, Campbell GS, and Comstock JB. Limitation of plant water use by rhizosphere and xylem conductance: results from a model. Plant, Cell and Environment 1998, 21:347 359.

[141] Steudle E. Water uptake by plant roots: an integration of views. Plant and Soil, 2000, 226: 45 56.

[142] Doussan C, Vercambre G, and Pages L. Modelling of the hydraulic architecture of root systems: An integrated approach to water absorption - distribution of axial and radial conductances in maize. Annals of Botany 1998, 81:225 232.

[143] Couvreur V, Vanderborght J, and Javaux M. A simple three-dimensional macroscopic root water uptake model based on the hydraulic architecture approach. Hydrology and Earth System Sciences 2012, 16:2957 2971. doi:10.5194/hess-16-2957-2012.

[144] Javaux M, Vanderborght J, Couvreur V, and Vereecken H. Root water uptake: From 3D biophysical processes to macroscopic modeling approaches. Vadose Zone J. 2013, 12:1 16. doi:10.2136/vzj2013.02.0042.

[145] Johnson DM, Sherrard ME, Domec JC, and Jackson RB. Role of aquaporin activity in regulating deep and shallow root hydraulic conductance during extreme drought. Trees 2014, 28:1323-1331. doi:10.1007/s00468-014-1036-8.

[146] Moshelion M, Halperin O, Wallach R, Oren R, and Way DA. Role of aquaporins in determining transpiration and photosynthesis in water-stressed plants: crop water-use efficiency, growth and yield. Plant, Cell and Environment 2014, Early View: , doi: 10.1111/pce.12410.

[147] Jungk AO. Dynamics of nutrient movement at the soil-root interface. Chapter in Plant roots: the hidden half, Marcel Dekker Inc., New York, 2002, 587-616. 
[148] Chapman N, Miller AJ, Lindsey K, and. Richard Whalley W. Roots, water, and nutrient acquisition: let's get physical. Trends in Plant Science, 2012, 17(12):701 710.

[149] Zelazny E, Vert G. Plant nutrition: root transporters on the move. Plant physiology, 2014, 166(2):500-508, doi:10.1104/pp.114.244475.

[150] Vrugt JA, vanWijk MT, Hopmans JW, and Simunek J. One-, two-, and three-dimensional root water uptake functions for transient modeling, Water Resour. Res. 2001, 37 (10):2457-2470. doi:10.1029/2000WR000027.

[151] Doussan C, Pierret A, Garrigues E, and Pages L. Water uptake by plant roots: II-modelling of water transfer in the soil root system with explicit account of flow within the root systemcomparison with experiments. Plant and Soil 2006, 283:99 117.

[152] Javaux M, Schroder T, Vanderborght J, and Vereecken H. Use of a three-dimensional detailed modeling approach for predicting root water uptake. Vadose Zone Journal 2008, 7: 1079-1088.

[153] Schneider CL, Attinger S, Delfs JO, and Hildebrandt H. Implementing small scale processes at the soil-plant interface - the role of root architectures for calculating root water uptake profiles. Hydrol. Earth Syst. Sci. 2010, 14:279 289. doi:10.5194/hess-14-279-2010.

[154] Dunbabin VM, Postma JA, Schnepf A, Pagès L, Javaux M, Wu L, Leitner D, Chen YL, Rengel Z, and Diggle AJ. Modelling root-soil interactions using three-dimensional models of root growth, architecture and function. Plant and Soil 2013, 372:93 124. doi:10.1007/s11104-013-1769-y.

[155] Manoli G, Bonetti S, Domec JC, Putti M, Katul G, and Marani M. Tree root systems competing for soil moisture in a 3D soil-plant model. Advances in Water Resources 2014, 66:32 42.

[156] Postma JA, Schurr U, and Fiorani F. Dynamic root growth and architecture responses to limiting nutrient availability: linking physiological models and experimentation. Biotechnology Advances 2014, 32(1):53-65.

[157] Warren JM, Hanson PJ, Iversen CM, Kumar J, Walker AP, and Wullschleger SD. Root structural and functional dynamics in terrestrial biosphere models - evaluation and recommendations. New Phytologist 2015, 205:59-78. doi: 10.1111/nph.1303.

[158] Feddes RA, Kowalik P, Kolinska-Malinka K, and Zaradny H. Simulation of field water uptake by plants using a soil water dependent root extraction function. Journal of Hydrology, 31:13 26, 1976.

[159] Feddes RA, Ho H, Bruen M, Dawson T, de Rosnay P, Dirmeyer P, Jackson RB, Kabat P, Kleidon A, Lilly, A and Pitmank AJ. Modeling root water uptake in hydrological and climate models. Bulletin of the American Meteorological Society 2001, 82(12):2797 2809. 
[160] Ivanov VY, Bras RL, and Vivoni ER. Vegetation-hydrology dynamics in complex terrain of semiarid areas: 1. A mechanistic approach to modeling dynamic feedbacks. Water Resources Research 2008 44(W03429). doi:10.1029/2006WR005588.

[161] Fatichi S, Ivanov VY, and Caporali E. A mechanistic ecohydrological model to investigate complex interactions in cold and warm water-controlled environments. 1 Theoretical framework and plot-scale analysis. Journal of Advances in Modeling Earth Systems 2012, 4(M05002).

[162] Daly E, Porporato A, and Rodriguez-Iturbe I. Coupled dynamics of photosynthesis, transpiration, and soil water balance. Part I: Upscaling from hourly to daily level. Journal of Hydrometeorology 2004, 5:546 558.

[163] Deckmyn G, Verbeeck H, de Beeck MO, Vansteenkiste D, Steppe K, and Ceulemans R. ANAFORE: A stand-scale process-based forest model that includes wood tissue development and labile carbon storage in trees. Ecological Modelling 2008, 215:345 368.

[164] Newman El. Resistance to water flow in soil and plant. I. Soil resistance in relation to amounts of root: theoretical estimate. J. Appl. Ecol. 1969, 6:1 12.

[165] Dixon HH and Joly J. On the ascent of sap. Philosophical Transactions of the Royal Society London, Series B, 186:563 576, 1894.

[166] Tyree MT. The cohesion-tension theory of sap ascent: current controversies. Journal of Experimental Botany 1997, 48(315):1753 1765.

[167] Münch E. Die Stoffbewegungen in der Pflanze . Gustav Fischer, Jena, Germany, 1930.

[168] De Schepper V, De Swaef T, Bauweraerts I, and Steppe K. Phloem transport: a review of mechanisms and controls. Journal of Experimental Botany 2013, 64:4839 4850. doi:10.1093/jxb/ert302.

[169] Ryan MG and Asao S. Phloem transport in trees. Tree Physiology 2014 34:1 4. doi:10.1093/treephys/tpt123.

[170] Pockman WT and Sperry JS. Vulnerability to xylem cavitation and the distribution of Sonoran vegetation. American Journal of Botany 2000, 87(9):1287-1299.

[171] Martínez-Vilalta J, Prat E, Oliveras I, and Piñol J. Xylem hydraulic properties of roots and stems of nine mediterranean woody species. Oecologia 2002, 133:19-29.

[172] Lopez OR, Kursar TA, Cochard H, and Tyree MT. Interspecific variation in xylem vulnerability to cavitation among tropical tree and shrub species. Tree Physiology, 25:1553 1562, 2005.

[173] Maherali H, Pockman WT, Jackson RB. Adaptive variation in the vulnerability of woody plants to xylem cavitation. Ecology, 2004, 85:2184-2199. 
[174] Meinzer FC, Johnson DM, Lachenbruch B, McCulloh KM, and Woodruff DR. Xylem hydraulic safety margins in woody plants: coordination of stomatal control of xylem tension with hydraulic capacitance. Functional Ecology 2009 23:922-930. doi: 10.1111/j.1365-2435.2009.01577.x.

[175] Domec JC and Gartner BL. Cavitation and water storage capacity in bole xylem segments of mature and young Douglas-fir trees. Trees 2001, 15:204 214.

[176] Steppe K, De Pauw DJW, Doody TM, and Teskey RO. Comparison of sap flux density using thermal dissipation, heat pulse velocity and heat field deformation methods. Agricultural and Forest Meteorology 2010 150:1046 1056.

[177] Hölttä T, Vesala T, Sevanto S, Perämäki M, and Nikinmaa E. Modeling xylem and phloem water flows in trees according to cohesion theory and Münch hypothesis. Trees Struct. Funct 2006, 20:67 78.

[178] Thompson MV and Holbrook NM. Application of a single-solute non-steady-state phloem model to the study of long-distance assimilate transport. J. Theor. Biol. 2003 220:419 455.

[179] Cochrane TT and Cochrane TA. Differences in the way potassium chloride and sucrose solutions effect osmotic potential of significance to stomata aperture modulation. Plant Physiology and Biochemistry 2009, 47:205-209.

[180] Woodruff DR, Bond BJ, and Meinzer FC. Does turgor limit growth in tall trees? Plant, Cell and Environment 2004, 27:229 236.

[181] Woodruff DR and Meinzer FC. Size-Dependent Changes in Biophysical Control of Tree Growth: The Role of Turgor Chapter in Size- and Age-Related Changes in Tree Structure and Function, 363384. Springer, Dordrecht, Netherlands, 2011.

[182] Turgeon R. The puzzle of phloem pressure. Plant Physiology 2010 154:578 581.

[183] Mencuccini M, Hölttä T, Sevanto S, and Nikinmaa E. Concurrent measurements of change in the bark and xylem diameters of trees reveal a phloem-generated turgor signal. New Phytologist 2013, 198:1143 1154 .

[184] Hölttä T, Mencuccini M, and Nikinmaa E. Linking phloem function to structure: Analysis with a coupled xylem-phloem transport model. Journal of Theoretical Biology 2009 259:325 337.

[185] Sevanto S, Hölttä T, and Holbrook NM. Effects of the hydraulic coupling between xylem and phloem on diurnal phloem diameter variation. Plant, Cell and Environment 2011, 34:690 703. doi: 10.1111/j.1365-3040.2011.02275.x. 
[186] Meinzer FC, James SA, Goldstein G, and Woodruff D. Whole-tree water transport scales with sapwood capacitance in tropical forest canopy trees. Plant Cell and Environment 2003, 26: 1147 1155, 2003.

[187] Scholz FG, Bucci SJ, Goldstein G, Meinzer FC, Franco AC, and Miralles-Wilhelm F. Biophysical properties and functional significance of stem water storage tissues in neotropical savanna trees. Plant, Cell, and Environment 2007, 30:236 248.

[188] Barnard DM, Meinzer FC, Lachenbruch B, McCulloh KA, Johnson DM, and Woodruff DR. Climate-related trends in sapwood biophysical properties in two conifers: avoidance of hydraulic dysfunction through coordinated adjustments in xylem efficiency, safety and capacitance. Plant, Cell and Environment 2011, 34(4):643-654.

[189] Verbeeck H, Steppe K, Nadezhdina N, De Beeck MO, Deckmyn GO, Meiresonne L, Lemeur R, Cermák J, Ceulemans R, and Janssens IA. Stored water use and transpiration in Scots pine: a modeling analysis with ANAFORE. Tree Physiology 2007 27:1671 1685.

[190] Cermák J, Kucera J, Bauerle WL, Phillips N, and Hinckely TM. Tree water storage and its diurnal dynamics related to sap flow and changes in stem volume in old-growth douglas-fir trees. Tree Physiology 2007, 27:181 198.

[191] Scholz FG, Phillips NG, Bucci SJ, Meinzer FC, and Goldstein G. Hydraulic Capacitance: Biophysics and Functional Significance of Internal Water Sources in Relation to Tree Size, Chapter in Size- and Age-Related Changes in Tree Structure and Function. Springer, Dordrecht, Netherlands, 2011, pages 341361.

Domecs

[192] Domec JC and Gartner BL. How do water transport and storage differ in coniferous earlywood and latewood? Journal of Experimental Botany 2002, 53:2369 2379.

[193] Domec JC and Gartner BL. Relationship between growth rates and xylem hydraulic characteristics in young, mature and old-growth ponderosa pine trees. Plant, Cell and Environment $200326: 471483$.

[194] Génard M, Fishman S, Vercambre G, Huguet JG, Bussi C, Besset J, and Habib R. A biophysical analysis of stem and root diameter variations in woody plants. Plant Physiology 2001, 126:188 202.

[195] Zweifel R, Item H, and Häsler R. Link between diurnal stem radius changes and tree water relations. Tree Physiology 2001 21:869 87.

[196] Zweifel R, Zimmermann L, Zeugin F, and Newbery DM. Intra-annual radial growth and water relations of trees: implications towards a growth mechanism. Journal of Experimental Botany 2006, 57(6):1445 1459. doi:10.1093/jxb/erj125. 
[197] Fernández JE and Cuevas MV. Irrigation scheduling from stem diameter variations: A review. Agricultural and Forest Meteorology 2010 150:135 151.

[198] King G, Fonti P, Nievergelt D, Buntgen U, and Frank D. Climatic drivers of hourly to yearly tree radius variations along a $6{ }^{\circ} \mathrm{C}$ natural warming gradient. Agricultural and Forest Meteorology 2013, 168:36 46, 2013.

[199] Köcher P, V. Horna, and C. Leuschner. Stem water storage in five coexisting temperate broadleaved tree species: significance, temporal dynamics and dependence on tree functional traits. Tree Physiology, 2013 33(8):817-832, doi:10.1093/treephys/tpt055.

[200] Katul GG, Leuning R, and Oren R. Relationship between plant hydraulic and biochemical properties derived from a steady-state coupled water and carbon transport model. Plant, Cell and Environment 2003 26:339 350.

[201] Loranty MM, Mackay DS, Ewers BE, Traver E, and Kruger EL. Competition for light between individual trees lowers reference canopy stomatal conductance: Results from a model. Journal of Geophysical Research-Biogeosciences 2010, 115(G04019). doi:10.1029/2010JG001377.

[202] Mackay DS, Roberts DE, Ewers BE, Sperry JS, McDowell NG, and Pockman WT. Interdependence of chronic hydraulic dysfunction and canopy processes can improve integrated models of tree response to drought. Water Resources Research 2015, 51, doi:10.1002/2015WR017244.

[203] Bohrer G, Mourad H, Laursen TA, Drewry D, Avissar R, Poggi D, Oren R, and Katul GG. Finite element tree crown hydrodynamics model $(\mathrm{FETCH})$ using porous media flow within branching elements: A new representation of tree hydrodynamics. Water Resources Research 2005, 41(W11404). doi:10.1029/2005WR004181.

[204] Janott M, Gayler S, Gessler A, Javaux M, Klier C, and Priesack E. A one-dimensional model of water flow in soil-plant systems based on plant architecture. Plant and Soil 2011, 341:233 256. doi:10.1007/s11104-010-0639-0.

[205] BittnerS, Legner N, Beese F, and Priesack E. Individual tree branch-level simulation of light attenuation and water flow of three F. sylvatica L. trees. Journal of Geophysical Research 2012, 117(G01037). doi:10.1029/2011JG001780.

[206] Hentschel R, Bittner S, Janott M, Biernath C, Holst J, Ferrio JP, Gessler A, and Priesack E. Simulation of stand transpiration based on a xylem water flow model for individual trees. Agricultural and Forest Meteorology 2013, 182-183: 3142.

[207] Chuang YL, Oren R, Bertozzi AL, Phillips N, and Katul GG. The porous media model for the hydraulic system of a conifer tree: Linking sap flux data to transpiration rate. Ecological Modelling 2006, 191:447 468 . 
[208] Hölttä T, Cochard H, Nikinmaa E, and Mencuccini M. Capacitive effect of cavitation in xylem conduits: results from a dynamic model. Plant, Cell \& Environment 2009, 32:10 21.

[209] Nikinmaa E, Sievänen R, and Hölttä T. Dynamics of leaf gas exchange, xylem and phloem transport, water potential and carbohydrate concentration in a realistic 3-D model tree crown. Annals of Botany 2014,114(4):653 666.

[210] Schiestl-Aalto P, Kulmala L, Mäkinen H, Nikinmaa E, and Mäkelä A. CASSIA - a dynamic model for predicting intra-annual sink demand and interannual growth variation in scots pine. New Phytologist 2015, 206:647 659. doi: 10.1111/nph.13275.

[211] Steppe K, De Pauw DJW, Lemeur R, and Vanrolleghem PA. A mathematical model linking tree sap flow dynamics to daily stem diameter fluctuations and radial stem growth. Tree Physiology 2005, 26:257 273.

[212] De Pauw DJW, Steppe K, and De Baets B. Identifiability analysis and improvement of a tree water flow and storage model. Mathematical Biosciences 2008, 211:314 332.

[213] De Schepper V and Steppe K. Development and verification of a water and sugar transport model using measured stem diameter variations. Journal of Experimental Botany 2010, 61: 20832099. doi:10.1093/jxb/erq018.

[214] De Schepper V and Steppe K. Tree girdling responses simulated by a water and carbon transport model. Annals of Botany 2011, 108:1147 1154. doi:10.1093/aob/mcr068.

[215]Daudet FA, Lacointe A, Gaudillere JP, and Cruiziat P. Generalized Münch coupling between sugar and water fluxes for modelling carbon allocation as affected by water status. Journal of Theoretical Biology 2002, 214:481 498. doi:10.1006/jtbi.2001.2473.

[216] Hsiao TC, Acevedo E, Fereres E, and Henderson DW. Stress metabolism: water stress, growth and osmotic adjustment. Philos. Trans. R. Soc. Lond. B Biol. Sci 1976, 273:479 500.

[217] Wang Z, Quebedeaux B, and Stutte GW. Osmotic adjustment: Effect of water stress on carbohydrates in leaves, stems and roots of apple. Aust. J. Plant Physiol 1995, 22:747 754.

[218] Bartlett MK, Scoffoni C, and Sack L. The determinants of leaf turgor loss point and prediction of drought tolerance of species and biomes: a global meta-analysis. Ecology Letters 2012 15:393 405.

[219] Cosgrove DJ. Growth of the plant cell wall. Nature Reviews Molecular Cell Biology, 2005, 6: 850-861, doi:10.1038/nrm1746.

[220] Hölttä T, Mäkinen H, Nöjd P, Mäkelä A, Nikinmaa E. A physiological model of softwood cambial growth. Tree Physiology, 2010, 30(10):1235-1252, doi:10.1093/treephys/tpq068. 
[221] Lockhart JA. An analysis of irreversible plant cell elongation. Journal of Theoretical Biology $1965,8: 264275$.

[222] Cosgrove D. Biophysical control of plant cell growth. Ann. Rev. Plant Physiol. 1986, 37: 377405.

[223] Boyer JS and Silk WK. Hydraulics of plant growth. Functional Plant Biology 2004, 31:761 773, 2004.

[224] Hsiao TC. Plant responses to water stress. Annu. Rev. Plant Physiol. 1973, 24:519 570.

[225] Muller B, Pantin F, Génard M, Turc O, Freixes S, Piques M, and Gibon Y. Water deficits uncouple growth from photosynthesis, increase $\mathrm{C}$ content, and modify the relationships between $\mathrm{C}$ and growth in sink organs. Journal of Experimental Botany 2011, 62(6):1715 1729. doi:10.1093/jxb/erq438.

[226] Tardieu F, Granier C, and Muller B. Water deficit and growth. Co-ordinating processes without an orchestrator? Current Opinion in Plant Biology 2011, 14:283 289.

[227] Cannell MGR and Thornley JHM. Modelling plant respiration : some guiding principles. Annals of Botany 2000, 85:45 54 .

[228] McDowell NG. Mechanisms linking drought, hydraulics, carbon metabolism, and mortality. Plant Physiology 2011, 155:1051 1059.

[229] Brando PM, Nepstad DC, Davidson EA, Trumbore SE, Ray D, and Camargo P. Drought effects on litterfall, wood production and belowground carbon cycling in an Amazon forest: results of a throughfall reduction experiment. Phil. Trans. R. Soc. B 2008, 363:1839-1848. doi:10.1098/rstb.2007.0031.

[230] Brzostek ER, Dragoni D, Schmid HP, Rahman AF, Sims D, Wayson CA, Johnson DJ, and Phillips RP. Chronic water stress reduces tree growth and the carbon sink of deciduous hardwood forests. Global Change Biology 2014, 20 (8):2531 2539. doi: 10.1111/gcb.12528.

[231] Fischer EM, Seneviratne SI, Vidale PL, Lüthi D, and Schär C. Soil moisture-atmosphere interactions during the 2003 European summer heat wave. Journal of Climate 2007, 20: 50815099.

[232] Lawlor DW and Tezara W. Causes of decreased photosynthetic rate and metabolic capacity in water-deficient leaf cells: a critical evaluation of mechanisms and integration of processes. Annals of Botany 2009, 103:561 579. doi:10.1093/aob/mcn244.

[233] Bartlett MK, Zhang Y, Kreidler N, Sun S, Ardy R, Cao K, and Sack L. Global analysis of plasticity in turgor loss point, a key drought tolerance trait. Ecology Letters 2014, 17:1580-1590. doi: 10.1111/ele.12374. 
[234] Hartmann $\mathrm{H}$, Ziegler $\mathrm{W}$, Kolle $\mathrm{O}$, and Trumbore S. Thirst beats hunger - declining hydration during drought prevents carbon starvation in Norway spruce saplings. New Phytologist 2013, 200:340-349. doi: 10.1111/nph.12331.

[235] Gaylord ML, Kolb TE, Pockman WT, Plaut JA, Yepez EA, Macalady AK, Pangle RE, and McDowell NG. Drought predisposes pinon-juniper woodlands to insect attacks and mortality. New Phytologist 2013, 198:567 578.

[236] Poyatos R, Aguadé D, Galiano L, Mencuccini M, and Martínez-Vilalta J. Drought-induced defoliation and long periods of near-zero gas exchange play a key role in accentuating metabolic decline of Scots pine. New Phytologist 2013, 220:388 401. doi: 10.1111/nph.12278.

[237] Penuelas J, Filella I, Zhang XY, Llorens L, Ogaya R, Lloret L, Comas P, Estiarte M, and Terradas J. Complex spatiotemporal phenological shifts as a response to rainfall changes. New Phytologist 2004, 161:837-846. doi:10.1111/j.1469-8137.2004.01003.x.

[238] Vico G, Thompson SE, Manzoni S, Molini A, Albertson JD, Almeida-Cortez JS, Fay PA, Feng X, Guswa AJ, Liu H, Wilson TG, and Porporato A. Climatic ecophysiological and phenological controls on plant ecohydrological strategies in seasonally dry ecosystems. Ecohydrology 2014, doi:10.1002/eco.1533.

[239] Manzoni S, Vico G, Thompson S, Beyer F, Weih M. Contrasting leaf phonological strategies optimize carbon gain under droughts of different duration. Advances in Water Resources, 2015. doi:10.1016/j.advwatres.2015.08.001.

[240] McDowell N, Pockman W, Allen C, Breshears DD, Cobb N, Kolb T, Sperry J, West A, Williams D, and Yepez E. Mechanisms of plant survival and mortality during drought: Why do some plants survive while others succumb to drought? New Phytologist 2008, 178:719 739. doi:10D1111/j.14698137D2008D02436.x.

[241] McDowell NG, Beerling DJ, Breshears DD, Fisher RA, Raffa KF, and Stitt M. The interdependent mechanisms underlying climate-driven vegetation mortality. Trends in Ecology and Evolution 2011, 26(10):523532.

[242] Sevanto S, McDowell NG, Dickman LT, Pangle R, and Pockman WT. How do trees die? A test of the hydraulic failure and carbon starvation hypotheses. Plant, Cell and Environment 2014, 37(1):153 161, doi: 10.1111/pce.1214.

[243] Allen CD, Macalady AK, Chenchouni H, Bachelet D, McDowell NG, Vennetier M, Kitzberger T, Rigling A, Breshears DD, Hogg EH(Ted), et al. A global overview of drought and heat-induced tree mortality reveals emerging climate change risks for forests. Forest Ecology and Management 2010, 259:660 684. 
[244] Phillips OL, van der Heijden G, Lewis SL, López-González G, Aragao LEOC, Lloyd J, Malhi Y, Monteagudo $A$, and Almeida $S$ et al. Drought-mortality relationships for tropical forests. New Phytologist 2010, 187:631 646.

[245] Choat B, Jansen S, Brodribb TJ, Cochard H, Delzon S, Bhaskar R, Bucci SJ, Feild TS, Gleason SM, Hacke UG, et al. Global convergence in the vulnerability of forests to drought. Nature, 2012, 491:752-755.

[246] Adams HD, Guardiola-Claramonte M, Barron-Gafford GA, Breshears DD, Villegas JC, Zou CB, Troch PA, Huxman TE. Temperature sensitivity of drought-induced tree mortality portends increased regional die-off under global change-type drought. Proceedings of the National Academy of Sciences USA, 2009, 106:7063-7066.

[247] Breshears DD, Myers OB, Meyer CW, Barnes FJ, Zou CB, Allen CD, McDowell NG, Pockman WT. Tree die-off in response to global change-type drought: mortality insights from a decade of plant water potential measurements. Frontiers in Ecology and the Environment, 2009, 7:185-189.

[248] Breshears DD, Adams HD, Eamus D, McDowell NG, Law DJ, Will RE, Williams AP, and Zou CB. The critical amplifying role of increasing atmospheric moisture demand on tree mortality and associated regional die-off. Frontiers in Plant Science, 2013, 4(266), doi:10.3389/fpls.2013.00266.

[249] McDowell NG, Fisher RA, Xu C, Domec JC, Hölttä T, Mackay DS, Sperry JS, Boutz A, Dickman L, Gehres $N$, et al. Evaluating theories of drought-induced vegetation mortality using a multimodelexperiment framework. New Phytologist 2013, 200:304 321.

[250] Meir P, Mencuccini M, and Dewar RC. Drought-related tree mortality: addressing the gaps in understanding and prediction. New Phytologist 2015, 1.

[251] Reed DE, Ewers BE, Pendall E. Impact of mountain pine beetle induced mortality on forest carbon and water fluxes. Environ. Res. Lett., 2014, 9:105004, doi:10.1088/1748-9326/9/10/105004.

[252] Monteith JL. Evaporation and environment. In G. E. Fogg, editor, Symposium Society Experimental Biology, The state and movement of water in living organisms, volume 19, pages 205 224. Cambridge University Press, London, 1965.

[253] Bonan GB. Forests and Climate Change: Forcings, Feedbacks, and the Climate Benefits of Forests. Science, 2008, 320: 1444-1449.

[254] Allen RG, Pereira LS, Raes D, and Smith M. Crop evapotranspiration-Guidelines for computing crop water requirements, volume 300 of FAO Irrigation and drainage paper. FAO- Food and Agriculture Organization of the United Nations, 1998.

[255] Richards LA. Capillary conduction of liquids through porous mediums. Physics 1931, 1:318 333. 
[256] Celia MA, Bouloutas ET, and Zarba RL. A general mass-conservative numerical solution for the unsaturated flow equation. Water Resources Research 1990, 26(7):1483 1496.

[257] Simunek J and van Genuchten MT. Modeling nonequilibrium flow and transport processes using HYDRUS. Vadose Zone J 2008, 7:782 797.

[258] Schwinning S. The ecohydrology of roots in rocks. Ecohydrology, 2010, 3:238-245, doi:10.1002/eco.134.

[259] Ogée J, Brunet $Y$, Loustau D, Berbigier $P$, and Delzon S. MuSICA, a $\mathrm{CO}_{2}$, water and energy multilayer, multileaf pine forest model: evaluation from hourly to yearly time scales and sensitivity analysis. Global Change Biology 2003, 9:697 717. doi: 10.1046/j.1365-2486.2003.00628.

[260] Oleson KW, Lawrence DM, Bonan GB, Flanner MG, Kluzek E, Lawrence PJ, Levis S, Swenson SC, and Thornton PE. Technical description of version 4.0 of the Community Land Model (CLM). Technical Report NCAR/TN-478+STR, Natl. Cent. for Atmos. Res., Boulder, Colorado, 2010.

[261] Drewry DT, Kumar P, Long S, Bernacchi C, Liang XZ, and Sivapalan M. Ecohydrological responses of dense canopies to environmental variability: 1 . Interplay between vertical structure and photosynthetic pathway. Journal of Geophysical Research 2010, 115(G04022), 2010. doi:10.1029/2010JG001340.

[262] Della Chiesa S, Bertoldi G, Niedrist G, Obojes N, Endrizzi S, Albertson JD, Wohlfahrt G, Hörtnagl $\mathrm{L}$, and Tappeiner $\mathrm{U}$. Modelling changes in grassland hydrological cycling along an elevational gradient in the Alps. Ecohydrology 2014, 7(6):1453 1473, 2014. doi:10.1002/eco.1471.

[263] Tague CL and Band LE. RHESSys: Regional Hydro-Ecologic Simulation System-An objectoriented approach to spatially distributed modeling of carbon, water, and nutrient cycling. Earth Interactions 2004, 8(19):1 42.

[264] Montaldo N, Rondena R, Albertson JD, and Mancini M. Parsimonious modeling of vegetation dynamics for ecohydrologic studies of water-limited ecosystems. Water Resources Research 2005, 41(W10416), 2005. doi:10.1029/2005WR004094.

[265] Kirschbaum MUF, Keith H, Leuning R, Cleugh HA, Jacobsen KL, van Gorsel E, and Raison J. Modelling net ecosystem carbon and water exchange of a temperate Eucalyptus delegatensis forest using multiple constraints. Agricultural and Forest Meteorology 2007, 145:48 68.

[266] Zhou X, Istanbulluoglu E, and Vivoni ER. Modeling the ecohydrological role of aspectcontrolled radiation on tree-grass-shrub coexistence in a semiarid climate, Water Resources Research, 49(5): 2872-2895. 
[267] Wang L, Koike T, Yang K, Jackson TJ, Bindlish R, and Yang D. Development of a distributed biosphere hydrological model and its evaluation with the southern great plains experiments (SGP97 and SGP99). Journal of Geophysical Research 2009, 114(D08107), 2014. doi:10.1029/2008JD010800.

[268] Huang M, Piao S, Sun Y, Ciais P, Cheng L, Mao J, Poulter B, Shi X, Zeng Z, and Wang Y. Change in terrestrial ecosystem water-use efficiency over the last three decades. Global Change Biology 2015, 21(6):2366 2378, doi: 10.1111/gcb.12873.

[269] Gitelson AA and Gamon JA. The need for a common basis for defining light-use efficiency: Implications for productivity estimation. Remote Sensing of Environment 2015, 156: 196 201, ISSN 00344257. doi: 10.1016/j.rse.2014.09.017.

$=$

[270] Anderson MC, Norman JM, Meyers TP, and Diak GR. An analytical model for estimating canopy transpiration and carbon assimilation fluxes based on canopy light-use efficiency. Agricultural and Forest Meteorology 2000, 101:265 289.

[271] Cervarolo G, Mendicino G, and Senatore A. A coupled ecohydrological-three-dimensional unsaturated flow model describing energy, $\mathrm{H}_{2} \mathrm{O}$ and $\mathrm{CO}_{2}$ fluxes. Ecohydrology 2010, 3:205 225, doi:10.1002/eco.111.

[272] Istanbulluoglu E, Wang T, and Wedin DA. Evaluation of ecohydrologic model parsimony at local and regional scales in a semiarid grassland ecosystem. Ecohydrology 2011, 5(1):121 142. doi:10.1002/eco.211.

[273] Niu GY, Paniconi C, Troch PA, Scott RL, Durcik M, Zeng X, Huxman T, and Goodrich DC. An integrated modelling framework of catchment-scale ecohydrological processes: 1 . Model description and tests over an energy-limited watershed. Ecohydrology 2014, 7(2):427 439, doi:10.1002/eco.1362.

[274] Arora VK. Modelling vegetation as a dynamic component in soil-vegetation-atmospheretransfer schemes and hydrological models. Reviews of Geophysics 2002, 40(2), 2002. doi:10.1029/2001RG000103.

[275] Friend AD, Stevens AK, Knox RG, and Cannell MGR. A process-based, terrestrial biosphere model of ecosystem dynamics (Hybrid v3.0). Ecological Modelling 1997, 95:249 287.

[276] Davi H, Barbaroux C, François C, and Dufrêne E. The fundamental role of reserves and hydraulic constraints in predicting LAl and carbon allocation in forests. Agricultural and Forest Meteorology 2009, 149:349 361.

[277] Sala A, Woodruff DR, and Meinzer FC. Carbon dynamics in trees: feast or famine? Tree Physiology 2012, 32:764 775, doi:10.1093/treephys/tpr143. 
[278] Fatichi S, Leuzinger S, and Körner C. Moving beyond photosynthesis: from carbon source to sink-driven vegetation modeling. New Phytologist 2014, 201:1086 1095, 2014 . doi: 10.1111/nph.12614.

[279] Manzoni S and Porporato A. Soil carbon and nitrogen mineralization: Theory and models across scales. Soil Biology \& Biochemistry 2009, 41:1355 1379. doi:10.1016/j.soilbio.2009.02.031.

[280] Parton WJ, Stewart JWB, and Cole CV. Dynamics of C, N, P and S in grassland soils - a model. Biogeochemistry 1988, 5:109 131.

[281] Dickinson RE, Berry JA, Bonan GB, Collatz GJ, Field CB, Fung IY, Goulden M, Hoffmann WA, Jackson RB, Myneni R, Sellers PJ, and Shaikh M. Nitrogen controls on climate model evapotranspiration. Journal of Climate 2002, 15:278 294.

[282] Kirschbaum MUF and Paul KI. Modelling $C$ and N dynamics in forest soils with a modified version of the CENTURY model. Soil Biology \& Biochemistry 2002, 34:341 354.

[283] Xu-Ri and Prentice IC. Terrestrial nitrogen cycle simulation with a dynamic global vegetation model. Global Change Biol. 2008, 14:1745 1764, doi:10.1111/j.1365-2486.2008.01625.x.

[284] Zaehle S and Friend A. Carbon and nitrogen cycle dynamics in the O-CN land surface model: 1. model description, site-scale evaluation, and sensitivity to parameter estimates. Global Biogeochemical Cycles 2010, 24(GB1005). doi:10.1029/2009GB003521.

[285] Orwin KH, Kirschbaum MUF, St John MG, and Dickie IA. Organic nutrient uptake by mycorrhizal fungi enhances ecosystem carbon storage: a model-based assessment. Ecology Letters 2011, 14:493 502, doi: 10.1111/j.1461-0248.2011.01611.x.

[286] Allison SD, Wallenstein MD, and Bradford MA. Soil-carbon response to warming dependent on microbial physiology. Nature Geosciences 2010, 3:336 340.

[287] Wieder WR, Bonan GB, and Allison SD. Global soil carbon projections are improved by modelling microbial processes. Nature Climate Change 2013, 3:909 912.

[288] Wang G, Post WM, and Mayes MA. Development of microbial-enzyme-mediated decomposition model parameters through steady-state and dynamic analyses. Ecological Applications 2013, 23(1):255 272.

[289] Manzoni S, Schimel JP, and Porporato A. Responses of soil microbial communities to water stress: results from a meta-analysis. Ecology 2012, 93:930 938.

[290] Li J, Wang G, Allison SD, Mayes MA, and Luo Y. Soil carbon sensitivity to temperature and carbon use efficiency compared across microbial-ecosystem models of varying complexity. Biogeochemistry 2014, 119:67 84. doi:10.1007/s10533-013-9948-8. 
[291] Manzoni S, Trofymow JA, Jackson RB, and Porporato A. Stoichiometric controls on carbon, nitrogen, and phosphorus dynamics in decomposing litter. Ecological Monographs 2010, 80 (1):89 106.

[292] Sinsabaugh RL, Manzoni S, Moorhead DL, and Richter A. Carbon use efficiency of microbial communities: stoichiometry, methodology and modelling. Ecology Letters 2013, 16:930 939. doi: 10.1111/ele.12113.

[293] Wu L, McGechan MB, McRoberts N, Baddeley JA, and Watson CA. SPACSYS: Integration of a 3D root architecture component to carbon, nitrogen and water cycling-model description. Ecological Modelling 2007, 200:343 359.

[294] Hinsinger P, Brauman A, Devau N, Gérard F, Jourdan C, Laclau JP, Le Cadre E, Jaillard B, and Plassard $C$. Acquisition of phosphorus and other poorly mobile nutrients by roots. Where do plant nutrition models fail? Plant Soil 2011, 348: 29 61. doi:10.1007/s11104-011-0903-y.

[295] Sterner RW, Elser JJ, and Vitousek P. Ecological Stoichiometry: The Biology of Elements from Molecules to the Biosphere. Princeton University Press, 2002.

[296] Field HA and Mooney C. The photosynthesis-nitrogen relationship in wild plants. In T.J. Givnish, editor, On the economy of plant form and function , 25 55. Cambridge University Press, 1986

[297] Evans JR. Photosynthesis and nitrogen relationship in leaves of C3 plants. Oecologia 1989, 78: 9 19.

[298] Kattge J, Knorr W, Raddatz T, and C. Wirth. Quantifying photosynthetic capacity and its relationship to leaf nitrogen content for global-scale terrestrial biosphere models. Global Change Biology 2009, 15:976 991. doi: 10.1111/j.1365-2486.2008.01744.x.

[299] Niinemets U, Keenan TF, and Hallik L. A worldwide analysis of within-canopy variations in leaf structural, chemical and physiological traits across plant functional types. New Phytologist 2015, 205:973 993. doi: 10.1111/nph.13096.

[300] Shen C, Niu J, and Phanikumar MS. Evaluating controls on coupled hydrologic and vegetation dynamics in a humid continental climate watershed using a subsurface-land surface processes model. Water Resources Research 2013, 49(5):2552-2572. doi:10.1002/wrcr.20189.

[301] Welsh AH, Peterson AT, and Altmann SA. The fallacy of averages. American Naturalist 1988, $132(2): 277288$.

[302] Pappas C, Fatichi S, Rimkus S, Burlando P, and Huber MO. The role of local scale heterogeneities in terrestrial ecosystem modeling. Journal of Geophysical Research-Biogeosciences 2015, 120(2):341 360. doi:10.1002/2014JG002735. 
[303] Dozier J and Frew J. Rapid calculation of terrain parameters for radiation modelling from digital elevation data. IEEE Transactions on Geoscience and Remote Sensing 1990, 28:963 969.

[304] Chen Y, Hall A, and Liou KN. Application of three-dimensional solar radiative transfer to mountains. Journal of Geophysical Research 2006, 111(D21111). doi:10.1029/2006JD007163.

[305] Bertoldi G, Rigon R, and Over TM. Impact of watershed geomorphic characteristics on the energy and water budgets. Journal of Hydrometeorology 2006, 7:389 403.

[306] Yetemen O, Istanbulluoglu El, Flores-Cervantes JH, Vivoni ER, and Bras RL. Ecohydrologic role of solar radiation on landscape evolution. Water Resources Research, 2015, 51 (2):1127-1157.

[307] Ivanov VY, Bras RL, and Vivoni ER. Vegetation-hydrology dynamics in complex terrain of semiarid areas: 2. Energy-water controls of vegetation spatiotemporal dynamics and topographic niches of favorability. Water Resources Research 2008, 44(W03430), doi:10.1029/2006WR005595.

[308] Fatichi S, Ivanov VY, and Caporali E. A mechanistic ecohydrological model to investigate complex interactions in cold and warm water-controlled environments. 2. Spatiotemporal analyses. Journal of Advances in Modeling Earth Systems 2012, 4(M05003).

[309] Band LE, Tague CL, Groffman P, and Belt K. Forest ecosystem processes at the watershed scale: hydrological and ecological controls of nitrogen export. Hydrological Processes 2001, 15:2013 2028. doi:10.1002/hyp.253.

[310] Lin L, Webster JR, Hwang T, and Band LE. Effects of lateral nitrate flux and instream processes on dissolved inorganic nitrogen export in a forested catchment: A model sensitivity analysis. Water Resources Research 2015, 51. doi:10.1002/2014WR015962.

[311] van Wijk MT and Rodriguez-Iturbe I. Tree-grass competition in space and time: insights from a simple cellular automata model based on ecohydrological dynamics. Water Resources Research 2002, 38(9):18 11815.

[312] Caracciolo D, Noto LV, Istanbulluoglu E, Fatichi S, and Zhou X. Climate change and ecotone boundaries: Insights from a cellular automata ecohydrology model in a mediterranean catchment with topography controlled vegetation pattern. Advances in Water Resources 2014, 73: 159175.

[313] Borgogno F, D'Odorico P, Laio F, and Ridolfi L. Mathematical models of vegetation pattern formation in ecohydrology. Rev. Geophys.2009, 47(RG1005). doi:10.1029/2007RG000256.

[314] Rietkerk M, Boerlijst MC, van Langevelde F, HilleRisLambers R, van de Koppel J, Kumar L, Prins $\mathrm{HHT}$, and de Roos AM. Self-organization of vegetation in arid ecosystems. Am. Nat. 2002, 160(4):524 530. 
[315] Ursino M. Modeling banded vegetation patterns in semiarid regions: Interdependence between biomass growth rate and relevant hydrological processes. Water Resources Research 2007, 43 (W04412), doi:10.1029/2006WR005292.

[316] Saco PM, Willgoose GR, and Hancock GR. Eco-geomorphology of banded vegetation patterns in arid and semi-arid regions. Hydrol. Earth Syst. Sci. 2007, 11:1717 1730.

[317] Baudena M, D'Andrea F, and Provenzale A. A model for soil-vegetation-atmosphere interactions in water-limited ecosystems. Water Resources Research 2008, 44(W12429). doi:10.1029/2008WR007172.

[318] Thompson S, Katul G, and McMahon SM. Role of biomass spread in vegetation pattern formation within arid ecosystems. Water Resources Research 2008, 44(W10421). doi:10.1029/2008WR006916.

[319] Accatino F, De Michele C, Vezzoli R, Donzelli D, and Scholes RJ. Tree-grass co-existence in savanna: Interactions of rain and fire. Journal of Theoretical Biology 2010, 267:235 242.

[320] Foti R and Ramírez JA. A mechanistic description of the formation and evolution of vegetation patterns. Hydrol. Earth Syst. Sci.2013, 17:63 84. doi:10.5194/hess-17-63-2013.

[321] Running SW and Coughlan JC. A general model of forest ecosystem processes for regional applications, I: Hydrologic balance, canopy gas exchange, and primary production processes. Ecological Modelling 1988, 42:125 154.

[322] Prentice IC, Cramer W, Harrison SP, Leemans R, Monsereud RA, and Solomon AM. A global biome model based on plant physiology and dominance, soil properties and climate. J. Biogeogr. 1992, 19:117134.

[323] Prentice IC, Sykes MT, and Cramer W. A simulation model for the transient effects of climate change on forest landscapes. Ecol. Modell. 1993, 65:51 70.

[324] Lüdeke MKB, Badeck FW, Otto RD, Häger C, Dönges S, Kindermann J, Würth G, Lang T, Jäkel U, Klaudius A, Ramge P, Habermehl S, and Kohlmaier GH. The Frankfurt Biosphere Model: A global process-oriented model of seasonal and long-term $\mathrm{CO}_{2}$ exchange between terrestrial ecosystems and the atmosphere. I. Model description and illustrative results for cold deciduous and boreal forests. Climate Research 1994, 4(2):143 166.

[325] Ruimy A, Dedieu G, and Saugier B. TURC: A diagnostic model of continental gross primary productivity and net primary productivity. Global Biogeochemical Cycles 1996, 10:269 285.

[326] Bonan GB. Land-atmosphere interactions for climate system models-coupling biophysical, biogeochemical, and ecosystem dynamical processes. Remote Sensing of Environment 1995, 51(1): 5773. 
[327] Bonan GB, Levis S, Sitch S, Vertenstein M, and Oleson KW. A dynamic global vegetation model for use with climate models: concepts and description of simulated vegetation dynamics. Global Change Biology 2003, 9:1543 1566. doi: 10.1046/j.1529-8817.2003.00681.x.

[328] Sitch S, Huntingford C, Gedney N, Levy PE, Lomas M, Piao L, Betts R, Cias P, Cox P, and Friedlingstein $P$. Evaluation of the terrestrial carbon cycle, future plant geography and climatecarbon cycle feedbacks using five dynamic global vegetation models (DGVMs). Global Change Biology 2008, 14(9):2015 2039. doi:10.1111/j.1365-2486.2008.01626.x.

[329] Prinn RG. Development and application of earth system models. Proceedings of the National Academy of Sciences USA 2012, 110:3673 3680. doi:10.1073/pnas.1107470109.

[330] Wenzel S, Cox PM, Eyring V, and Friedlingstein P. Emergent constraints on climate carbon cycle feedbacks in the CMIP5 Earth system models. J. Geophys. Res. Biogeosci. 2014, 119, doi:10.1002/2013JG00259.

[331] Dickinson RE, Henderson-Sellers A, and Kennedy PJ. Biosphere-atmosphere transfer scheme (BATS) version 1E as coupled to the NCAR Community Climate Model. Technical Report NCAR/TN387+STR, Natl. Cent. for Atmos. Res., Boulder, Colorado, 1993.

[332] Thornton PE, Lamarque JE, Rosenbloom NA, and Mahowald NM. Influence of carbon-nitrogen cycle coupling on land model response to $\mathrm{CO}_{2}$ fertilization and climate variability. Global Biogeochemical Cycles 2007, 21(GB4018). doi:10.1029/2006GB002868.

[333] Prentice IC, Bondeau A, Cramer W, Harrison SP, Hickler T, Lucht W, Sitch S, Smith B, and Sykes MT. Dynamic global vegetation modeling: quantifying terrestrial ecosystem responses to large-scale environmental change. In Canadell JP, Pataki DE, and Pitelka LF, editors, Terrestrial ecosystems in a changing world 2007, chapter 15. Springer, Berlin, Heidelberg.

[334] Levis S. Modeling vegetation and land use in models of the Earth System. WIREs: Climate Change 2010, 1(6):840 856. doi: 10.1002/wcc.83.

[335] Quillet A, Peng C, and Garneau M. Toward dynamic global vegetation models for simulating vegetation-climate interactions and feedbacks: recent developments, limitations, and future challenges. Environmental Reviews 2010, 18:333 353. doi: 10.1139/A10-016.

[336] Medlyn BE, Duursma RA, and Zeppel MJB. Forest productivity under climate change: a checklist for evaluating model studies. WIREs: Climate Change 2011, 2(3):332 355. doi: 10.1002/wcc.108.

[337] Pappas C, Fatichi S, Leuzinger S, Wolf A, and Burlando P. Sensitivity analysis of a process-based ecosystem model: Pinpointing parameterization and structural issues. Journal of Geophysical Research: Biogeosciences 2013, 118(2):505 528. doi: 10.1002/jgrg.20035. 
[338] Arain MA, Yuan F, and Black TA. Soil-plant nitrogen cycling modulated carbon exchanges in a western temperate conifer forest in Canada. Agricultural and Forest Meteorology 2006, 140:171 192.

[339] Wang YP, Houlton BZ, and Field CB. A model of biogeochemical cycles of carbon, nitrogen, and phosphorus including symbiotic nitrogen fixation and phosphatase production. Global Biogeochemical Cycles 2007, 21(GB1018). doi:10.1029/2006GB002797.

[340] Goll DS, Brovkin V, Parida BR, Reick CH, Kattge J, Reich PB, van Bodegom PM, and Niinemets U. Nutrient limitation reduces land carbon uptake in simulations with a model of combined carbon, nitrogen and phosphorus cycling. Biogeosciences 2012, 9:3547 3569. doi:10.5194/bg-9-3547-2012.

[341] Yang $X$, Thornton PE, Ricciuto DM, and Post WM. The role of phosphorus dynamics in tropical forests - a modeling study using CLM-CNP. Biogeosciences 2014, 11:1667 1681. doi:10.5194/bg-111667-2014.

[342] Zaehle S and Dalmonech D. Carbon-nitrogen interactions on land at global scales: current understanding in modelling climate biosphere feedbacks. Current Opinion in Environmental Sustainability 20113:311 320. doi:10.1016/j.cosust.2011.08.008.

[343] Bugmann HKM, Yan X, Sykes MT, Martin P, Lindner M, Desanker PV, Cumming SG. A comparison of forest gap models: Model structure and behaviour. Climatic Change, 1996, 34:289313.

[344] Sitch S, Smith B, Prentice IC, Arneth A, Bondeau A, Cramer W, Kaplan JO, Levis S, Lucht W, Sykes MT, Thonicke $\mathrm{K}$, and Venevski S. Evaluation of ecosystem dynamics, plant geography and terrestrial carbon cycling in the LPJ dynamic global vegetation model. Global Change Biology 2003, 9:161 185

[345] Krinner G, Viovy N, de Noblet-Ducoudre N, Ogée J, Polcher J, Friedlingstein P, Ciais P, Sitch S, and Prentice IC. A dynamic global vegetation model for studies of the coupled atmospherebiosphere system. Global Biogeochemical Cycles 2005, 19(GB1015). doi:10.1029/2003GB002199.

[346] West GB, Enquist BJ, and Brown JH. A general quantitative theory of forest structure and dynamics. Proceedings of the National Academy of Sciences USA 2009, 106(17):7040 7045. doi:10.1073/pnas.0812294106.

[347] Moorcroft PR, Hurtt GC, and Pacala SW. A method for scaling vegetation dynamics: the ecosystem demography model (ED). Ecological Monographs 2001 71(4):557 585.

[348] Smith B, Prentice IC, and Sykes MT. Representation of vegetation dynamics in modelling of terrestrial ecosystems: comparing two contrasting approaches within European climate space. Global Ecology and Biogeography 2001, 10:621 637. 
[349] Medvigy D, Wofsy SD, Munger JW, Hollinger DY, and Moorcroft PR. Mechanistic scaling of ecosystem function and dynamics in space and time: Ecosystem Demography model version 2. Journal of Geophysical Research 2009, 114(G01002). doi:10.1029/2008JG000812.

[350] Kim Y, Knox RG, Longo M, Medvigy D, Hutyra LR, Pyle EH, Wofsy SC, Bras RL, and Moorcroft PR. Seasonal carbon dynamics and water fluxes in an Amazon rainforest. Global Change Biology 2012, 18:1322 1334. doi: 10.1111/j.1365-2486.2011.02629.x.

[351] Medvigy D and Moorcroft PR. Predicting ecosystem dynamics at regional scales: An evaluation of a terrestrial biosphere model for the forests of northeastern North America. Philos. Trans. R. Soc. London, Ser. B 2012, 367:222-235. doi:10.1098/rstb.2011.0253.

[352] Dietze MC and Matthes JH. A general ecophysiological framework for modelling the impact of pests and pathogens on forest ecosystems. Ecology Letters 2014, 17:1418 1426, 2014. doi:10.1111/ele.12345.

[353] Pavlick R, Drewry DT, Bohn K, Reu B, and Kleidon A. The Jena Diversity-Dynamic Global Vegetation Model (JeDi-DGVM): a diverse approach to representing terrestrial bio-geography and biogeochemistry based on plant functional trade-o s. Biogeosciences 2013,10:4137 4177. doi:10.5194/bg-10-4137-2013 1058.

[354] Zeppel MJB, Adams HD, and Anderegg WRL. Mechanistic causes of tree drought mortality: recent results, unresolved questions and future research needs. New Phytologist 2011, 192:800803. doi: 10.1111/j.1469-8137.2011.03960.x.

[355] Franklin O, Aoki K, and Seidl R. A generic model of thinning and stand density effects on forest growth, mortality and net increment. Ann. For. Sci. 2009, 66(815). doi:10.1051/forest/2009073.

[356] Manusch C, Bugmann H, Heiri C, and Wolf A. Tree mortality in dynamic vegetation models -a key feature for accurately simulating forest properties. Ecological Modelling 2012, 243:101 111.

[357] Cox PM, Betts RA, Collins M, Harris PP, Huntingford C, and Jones CD. Amazonian forest dieback under climate-carbon cycle projections for the 21st century. Theoretical and Applied Climatology 2004, 78(1-3):137 156.

[358] Malhi Y, Roberts JT, Betts RA, Killeen TJ, Li W, and Nobre CA. Climate change, deforestation, and the fate of the amazon. Science 2008, 319:169 172.

[359] Malhi Y, Arag ao LEOC, Galbraith D, Huntingford C, Fisher R, Zelazowski P, Sitch S, McSweeney $\mathrm{C}$, and Meir P. Exploring the likelihood and mechanism of a climate-change-induced dieback of the Amazon rainforest. Proceedings of the National Academy of Sciences USA 2008, 106(49):2061020615. doi:10.1073/pnas.0804619106. 
[360] Nepstad DC, Stickler CM, Soares-Filho B, and Merry F. Interactions among Amazon land use, forests and climate: prospects for a near-term forest tipping point. Phil. Trans. R. Soc. B 2008, 363:1737 1746.

[361] Davidson EA, de Araújo AC, Artaxo P, Balch JK, Brown IF, Bustamante MMC, Coe MT, DeFries RS, Munger W, Keller $M$ et al. The amazon basin in transition. Nature, 2012, 481:321-328, doi:10.1038/nature10717.

[362] Brienen RJW, Phillips OL, Feldpausch TR, Gloor E, Baker TR, Lloyd J, Lopez-Gonzalez G, Monteagudo-Mendoza A, Malhi Y, Lewis SL, et al. Long-term decline of the amazon carbon sink. Nature 2015, 519:344 348. doi:10.1038/nature14283.

[363] Markewitz D, Devine S, Davidson EA, Brando P, and Nepstad DC. Soil moisture depletion under simulated drought in the Amazon: impacts on deep root uptake. New Phytologist 2010, 187:592607. doi:10.1111/j.1469-8137.2010.03391.x.

[364] Ivanov VY, Hutyra LR, Wofsy SC, Munger JW, Saleska SR, de Oliveira RC, Jr., and de Camargo PB. Root niche separation can explain avoidance of seasonal drought stress and vulnerability of overstory trees to extended drought in a mature Amazonian forest. Water Resources Research, 2012, 48(W12507), doi:10.1029/2012WR011972.

[365] Powell TL, Galbraith DR, Christoffersen BO, Harper A, Hewlley M, Imbuzeiro A, Rowland L, Almeida S, Brando PM, Lola da Costa AC, et al. Confronting model predictions of carbon fluxes with measurements of Amazon forests subjected to experimental drought. New Phytologist 2013, 200:350 365. doi: 10.1111/nph.12390.

[366] Gatti LV, Gloor M, Miller JB, Doughty CE, Malhi Y, Domingues LG, Basso LS, Martinewski A, Correia CSC, Borges VF, et al. Drought sensitivity of Amazonian carbon balance revealed by atmospheric measurements. Nature 2014, 506:76. doi:10.1038/nature12957.

[367] Brando PM, Goetz SJ, Baccini A, Nepstad DC, Beck PSA, and Christman MC. Seasonal and interannual variability of climate and vegetation indices across the Amazon. Proceedings of the National Academy of Sciences USA 2010 107(33):14685 14690. doi:10.1073/pnas.0908741107.

[368] Fu R, Yin L, Li W, Arias PA, Dickinson RE, Huang L, Chakraborty S, Fernandes K, Liebmann B, Fisher R, and Myneni RB. Increased dry-season length over southern Amazonia in recent decades and its implication for future climate projection. Proceedings of the National Academy of Sciences USA 2013 110(45): 18110-18115. doi:10.1073/pnas.1302584110.

[369] Knox R, Bisht G, Wang J, and Bras RL. Precipitation variability over the forest to non-forest transition in southwestern Amazonia. Journal of Climate 2011 24:2368 2377. 
[370] Butt N, de Oliveira PA, and Costa MH. Evidence that deforestation affects the onset of the rainy season in Rondonia, Brazil. Journal of Geophysical Research 2011, 116(D11120). doi:10.1029/2010JD015174.

[371] Khanna J and Medvigy D. Strong control of surface roughness variations on the simulated dry season regional atmospheric response to contemporary deforestation in Rondônia, Brazil. Journal of Geophysical Research, Atmos. 2014, 119:13067-13078, 2014. doi:10.1002/2014JD022278.

[372] Myers-Smith IH, Forbes BC, Wilmking M, Hallinger M, Lantz T, Blok D, Tape KD, Macias-Fauria $M$, Sass-Klaassen $U$, Lévesque $E$ et al. Shrub expansion in tundra ecosystems: dynamics, impacts and research priorities. Environ. Res. Lett. 2011, 6(045509). doi:10.1088/1748-9326/6/4/045509.

[373] Loranty MM and Goetz SJ. Shrub expansion and climate feedbacks in Arctic tundra. Environ. Res. Lett. 2012, 7(011005). doi:10.1088/1748-9326/7/1/011005.

[374] Pomeroy JW, Bewley DS, Essery RLH, Hedstrom NR, Link T, Granger RJ, Sicart JE, Ellis CR, and Janowicz JR. Shrub tundra snowmelt. Hydrol. Process. 2006, 20:923 941. doi:10.1002/hyp.6124.

[375] Pearson RG, Phillips SJ, Loranty MM, Beck PSA, Damoulas T, Knight SJ, and Goetz SJ. Shifts in Arctic vegetation and associated feedbacks under climate change. Nature Climate Change 2013, 3:673 677.

[376] Drake BG, Gonzàlez-Meler MA, and Long SP. More efficient plants: A consequence of rising atmospheric $\mathrm{CO}_{2}$ ? Annu. Rev. Plant Physiol. Plant Mol. Biol. 1997, 48:609 639.

[377] Ainsworth EA and Rogers A. The response of photosynthesis and stomatal conductance to rising $\left[\mathrm{CO}_{2}\right]$ : mechanisms and environmental interactions. Plant, Cell and Environment 2007, 30:258 270. doi:10.1111/j.1365-3040.2007.01641.x.

[378] Hickler T, Smith B, Prentice IC, Mjöfors K, Miller P, Arneth A, and Sykes MT. $\mathrm{CO}_{2}$ fertilization in temperate FACE experiments not representative of boreal and tropical forests. Global Change Biology 2008, 14(7):1531 1542, 2008. doi: 10.1111/j.1365-2486.2008.01598.x.

[379] Körner C. Plant $\mathrm{CO}_{2}$ responses: an issue of definition, time and resource supply. New Phytologist, 172:393 411, 2006. 10.1111/j.1469-8137.2006.01886.x.

[380] Leuzinger S, Luo Y, Beier C, Dieleman W, Vicca S, and Körner C. Do global change experiments overestimate impacts on terrestrial ecosystems? Trends in Ecology and Evolution 2011, 26(5). doi:10.1016/j.tree.2011.02.011.

[381] Gedney N, Cox PM, Bletts RA, Boucher O, Huntingford C, and Stott PA. Detection of a direct carbon dioxide effect in continental river runoff records. Nature 2006, 439:835838. 
[382] Betts RA, Boucher O, Collins M, Cox PM, Falloon PD, Gedney N, Hemming DL, Huntingford C, Jones $C D$, Sexton $D M H$, and Webb MJ. Projected increase in continental runoff due to plant responses to increasing carbon dioxide. Nature 2007, 448:1037 1041. doi:10.1038/nature06045.

[383] Huntingford C, Zelazowski P, Galbraith D, Mercado LM, Sitch S, Fisher R, Lomas M, Walker AP, Jones $\mathrm{CD}$, Booth $\mathrm{BBB}$, et al. Simulated resilience of tropical rainforests to $\mathrm{CO}_{2}$-induced climate change. Nature Geoscience, 2013 6: 268 273, doi:10.1038/ngeo1741.

[384] Schimel D, Stephens BB, and Fisher JB. Effect of increasing $\mathrm{CO}_{2}$ on the terrestrial carbon cycle. Proceedings of the National Academy of Sciences USA 2015, 112(2):436 441.

[385] Körner C, Morgan JA, and Norby RJ. $\mathrm{CO}_{2}$ fertilization: when, where, how much? Chapter in Terrestrial ecosystems in a changing world, Springer, Berlin, Germany, 2007.

[386] Norby RJ and Zak DR. Ecological lessons from free-Air $\mathrm{CO}_{2}$ enrichment (FACE) experiments. Annu. Rev. Ecol. Evol. Syst. 2011, 42:181 203. doi:10.1146/annurev-ecolsys-102209-144647.

[387] van der Sleen P, Groenendijk P, Vlam M, Anten NPR, Boom A, Bongers F, Pons TL, Terburg G, and Zuidema PA. No growth stimulation of tropical trees by 150 years of $\mathrm{CO}_{2}$ fertilization but wateruse efficiency increased. Nature Geoscience 2015, 8:24 28. doi:10.1038/NGEO2313.

[388] Medvigy D, Wofsy SC, Munger JW, and Moorcroft PR. Responses of terrestrial ecosystems and carbon budgets to current and future environmental variability. Proc. Natl. Acad. Sci. USA 2010, 107(18):8275 8280. doi: 10.1073/pnas.0912032107.

[389] Paschalis A, Fatichi S, Katul GG, and Ivanov VY. Cross-scale impact of climate temporal variability on ecosystem water and carbon fluxes. Journal of Geophyisical Research-Biogeosciences 2015. doi: 10.1002/2015JG003002

[390] Mutke J and Barthlott W. Patterns of vascular plant diversity at continental to global scales. Biologiske skrifter 2005, 55:521 531.

[391] Bonan GB, Levis S, Kergoat L, and Oleson KW. Landscapes as patches of plant functional types: An integrating concept for climate and ecosystem models. Global Biogeochemical Cycles 2002, 16(2). doi:10.1029/2000GB001360.

[392] Fyllas NM, Gloor E, Mercado LM, Sitch S, Quesada CA, Domingues TF, Galbraith DR, TorreLezama A, Vilanova E, Ramírez-Angulo E, et al. Analysing Amazonian forest productivity using a new individual and trait-based model (TFS v.1). Geoscientific Model Development 2014, 7:1251 1269. doi:10.5194/gmd-7-1251-2014.

[393] Pappas C. Modeling terrestrial carbon and water dynamics: A critical appraisal and ways forward. PhD thesis, ETH Zurich, 2014. 
[394] Sakschewski B, von Bloh W, Boit A, Rammig A, Kattge J, Poorter L, Peñuelas J, and Thonicke K. Leaf and stem economics spectra drive diversity of functional plant traits in a dynamic global vegetation model. Global Change Biology, - 2015,. doi: 10.1111/gcb.12870.

[395] Verheijen LM, Aerts R, Brovkin V, Cavender-Bares J, Cornelissen JHC, Kattge J, and van Bodegom PM. Inclusion of ecologically based trait variation in plant functional types reduces the projected land carbon sink in an earth system model. Global Change Biology, - 2015. doi: 10.1111/gcb.12871.

[396] Wright IJ, Reich PB, Westoby M, Ackerly DD, Baruch Z, Bongers F, Cavender-Bares J, Chapin T, Cornelissen JHC, Diemer M, et al The worldwide leaf economics spectrum. Nature 2004, 428:821 827.

[397] Chave J, Coomes D, Jansen S, Lewis SL, Swenson NG, and Zanne AE. Towards a worldwide wood economics spectrum. Ecology Letters 2009, 12:351 366. doi:10.1111/j.14610248.2009.01285.x.

[398] Manzoni S, Vico G, Porporato A, and Katul G. Biological constraints on water transport in the soil-plant-atmosphere system. Advances in Water Resources 2013, 51: 292304.

[399] Reich PB, Walters MB, and Ellsworth DS. From tropics to tundra: global convergence in plant functioning. Proc. NatI. Acad. Sci. USA 1997, 94:13730 13734.

[400] Reich PB. The world-wide 'fast-slow' plant economics spectrum: a traits manifesto. Journal of Ecology 2014, 102:275 301. doi: 10.1111/1365-2745.12211.

[401] ter Steege H, Pitman NCA, Sabatier D, Baraloto C,. Salom ao RP, Guevara JE, Phillips OL, Castilho CV, Magnusson WE, Molino JF, Monteagudo A, Vargas PN. Hyperdominance in the amazonian tree flora. Science 2013, 342:1243092. doi:10.1126/science.1243092.

[402] Saxton KE and Rawls WJ. Soil water characteristic estimates by texture and organic matter for hydrologic solutions. Soil Science Society of America Journal 2006, 70:1569 1578. doi:10.2136/sssaj2005.0117.

[403] Romano N, Nasta P, Severino G, and Hopmans JW. Using bimodal lognormal functions to describe soil hydraulic properties. Soil Sci. Soc. Am. J. 2011, 75:468 480. doi:10.2136/sssaj2010.0084.

[404] Yang $X$, Post WM, Thornton PE, and Jain A. The distribution of soil phosphorus for global biogeochemical modeling. Biogeosciences 2013, 10:2525-2537. doi:10.5194/bg-10-2525-2013.

[405] de Brogniez D, Ballabio C, Stevens A, Jones RJ, Montanarella L, and van Wesemael B. A map of the topsoil organic carbon content of Europe generated by a generalized additive model. European Journal of Soil Science 2015, 66:121 134. doi: 10.1111/ejss.12193. 
[406] Dietze MC, Sala A, Carbone MS, Czimczik Cl, Mantooth JA, Richardson AD, and Vargas R. Nonstructural carbon in woody plants. Annu Rev Plant Biol 2014, 65:667 687. doi:10.1146/annurevarplant-050213-040054.

[407] Aubinet M, Grelle A, Ibrom A, Rannik Ü, Moncrie J, Foken T, Kowalski AS, Martin PH, Berbigier P, Bernhofer C, Clement R, Elbers J, Granier A, Grunwald T, Morgenstern K, Pilegaard K, Rebmann C, Snijders $W$, Valentini R, and Vesala T. Estimates of the annual net carbon and water exchange of forests: the EUROFLUX methodology. 30:113 175, 2000.

[408] Baldocchi D, Falge E, Gu L, Olson R, Hollinger D, Running S, Anthoni P, Bernhofer C, Davis K, Evans R, et al. FLUXNET: A new tool to study the temporal and spatial variability of ecosystem-scale carbon dioxide, water vapor, and energy flux densities. Bulletin of the American Meteorological Society 2001, 82(11):2415 2434.

[409] Baldocchi DD. Assessing the eddy covariance technique for evaluating carbon dioxide exchange rates of ecosystems: Past, present and future. Global Change Biology 2003 9(4):479 492.

[410] Baldocchi DD. Breathing of the terrestrial biosphere: lessons learned from a global network of carbon dioxide ux measurement systems. Australian Journal of Botany 2008 56:1 26.

[411] Aubinet M, Vesala T, and Papale D. Eddy Covariance: A Practical Guide to Measurement and Data Analysis. Springer Atmospheric Sciences. Springer Netherlands, 2012.

[412] Robinson DA, Campbell CS, Hopmans JW, Hornbuckle BK, Jones SB, Knight R, Ogden F, Selker J, and Wendroth $\mathrm{O}$. Soil moisture measurements for ecological and hydrological watershed scale observatories: A review. Vadose Zone Journal 2008, 7:358 389. doi:10.2136/vzj2007.0143.

[413] Vereecken H, Huisman JA, Bogena HR, Vanderborght J, Vrugt JA, and Hopmans JW. On the value of soil moisture measurements in vadose zone hydrology: A review. Water Resources Research 2008 44(W00D06). doi:10.1029/2008WR006829.

[414] He L, Ivanov VY, Bohrer G, Thomsen JE, Vogel CS, and Moghaddam. M. Temporal dynamics of soil moisture in a northern temperate mixed successional forest after a prescribed intermediate disturbance. Agricultural and Forest Meteorology 2013 180:22 33.

[415] Fatichi S, Katul GG, Ivanov VY, Pappas C, Paschalis A, Consolo A, Kim J, Burlando P. Abiotic and biotic controls of soil moisture spatio-temporal variability and the occurrence of hysteresis. Water Resources Research, 2015, 51(5):3505-3524, doi:10.1002/2014WR016102.

[416] Falge E, Baldocchi D, Olson R, Anthoni P, Aubinet M, Bernhofer C, Burba G, Ceulemans R, Clement R. Gap filling strategies for defensible annual sums of net ecosystem exchange. Agricultural and Forest Meteorology 2001, 107(1):43 69. 
[417] Moffat AM, Papale D, Reichstein M, Hollinger DY, Richardson AD, BarrAG, Beckstein C, Braswell $\mathrm{BH}$, Churkina G, Desai AR, et al. Comprehensive comparison of gap-filling techniques for eddy covariance net carbon fluxes. Agricultural and Forest Meteorology 2007, 147(3-4):209 232.

[418] Wilson K, Goldstein A, Falge E, Aubinet M, Baldocchi D, Berbigier P, Bernhofer C, Ceulemans R, Dolman $\mathrm{H}$, Field $\mathrm{C}$, et al. Energy balance closure at FLUXNET sites. Agricultural and Forest Meteorology 2002, 113:223 243.

[419] Leuning R, van Gorsel E, Massman WJ, and Isaac PR. Reflections on the surface energy imbalance problem. Agricultural and Forest Meteorology $2012 \quad 156: 65 \quad 74$. doi:10.1016/j.agrformet.2011.12.002.

[420] Liu C, Zhang X, and Zhang Y. Determination of daily evaporation and evapotranspiration of winter wheat and maize by large-scale weighing lysimeter and micro-lysimeter. Agricultural and Forest Meteorology 2002, 111(2):109 120, 2002.

[421] Seneviratne SI, Lehner I, Gurtz J, Teuling AJ, Lang H, Moser U, Grebner D, Menzel L, Schro K, Vitvar T, and Zappa M. Swiss prealpine Rietholzbach research catchment and lysimeter: 32 year time series and 2003 drought event. Water Resources Research 2012, 48(W06526).

[422] Lischke $\mathrm{H}$ and Löffler TJ. Intraspecific density dependence is required to maintain species diversity in spatio-temporal forest simulations with reproduction. Ecological Modelling 2006198 (34):341 361. doi:10.1016/j.ecolmodel.2006.05.005.

[423] Nepstad DC, Tohver IM, Ray D, Moutinho P, and Cardinot G. Mortality of large trees and lianas following experimental drought in an Amazon forest. Ecology 2007, 88:2259 2269.

[424] Babst F, Alexander MR, Szejner P, Bouriaud O ,Klesse S, Roden J, Ciais P, Poulter B, Frank D, Moore DJP and Trouet V. A tree-ring perspective on the terrestrial carbon cycle. Oecologia 2014, 176:307 322. doi:10.1007/s00442-014-3031-6.

[425] Fatichi S and Leuzinger S. Reconciling observations with modeling: the fate of water and carbon allocation in a mature deciduous forest exposed to elevated $\mathrm{CO}_{2}$. Agricultural and Forest Meteorology 2013, 174-175:144 157. doi:10.1016/j.agrformet.2013.02.005.

[426] De Kauwe MG, Medlyn BE, Zaehle S, Walker AP, Dietze MC, Hickler T, Jain AK, Luo Y, Parton WJ, Prentice IC, et al. Forest water use and water use efficiency at elevated $\mathrm{CO}_{2}$ : a model-data intercomparison at two contrasting temperate forest FACE sites. Global Change Biology 2013, 19:1759 1779. doi: 10.1111/gcb.12164.

[427] Zaehle S, Medlyn BE, De KauweMG, WalkerAP, Dietze MC, Hickler T, Luo Y, Wang YP, El-Masri $B$, Thornton $P$, et al. Evaluation of 11 terrestrial carbon-nitrogen cycle models against observations from two temperate free-Air $\mathrm{CO}_{2}$ enrichment studies. New Phytologist 2014, 202:803 822. doi: 10.1111/nph.12697. 
[428] Medlyn BE, Zaehle S, De Kauwe MG, Walker AP, Dietze MC, Hanson PJ, Hickler T, Jain AK, Luo $\mathrm{Y}$, Parton $\mathrm{W}$, et al. Using ecosystem experiments to improve vegetation models. Nature Climate Change 2015, 5:528-534. doi:10.1038/nclimate2621.

[429] Smith NG, Rodgers VL, Brzostek ER, Kulmatiski A, Avolio ML, Hoover DL, Koerner SE, Grant K, Jentsch A, Fatichi $S$, and Niyogi D. Towards a better integration of biological data from precipitation manipulation experiments into Earth system models. Reviews of Geophysics 2014, 52(3):412 434. doi:10.1002/2014RG000458.

[430] Kayler ZE, De Boeck HJ, Fatichi S, Grünzweig JM, Merbold L, Beier C, McDowell N, and Dukes JS. Experiments to confront the environmental extremes of climate change. Frontiers in Ecology and the Environment 2015, 13(4):219 225. doi: 10.1890/140174.

[431] Schimel D, Pavlick R, Fisher JB, Asner GP, Saatchi S, Townsend P, Miller C, Frankenberg C, Hibbard K, and Cox P. Observing terrestrial ecosystems and the carbon cycle from space. Global Change Biology 2015, 21:1762 1776, 2015. doi: 10.1111/gcb.12822.

[432] Vivoni ER, Rango A, Anderson CA, Pierini NA, Schreiner-McGraw AP, Saripalli S, Laliberte AS. Ecohydrology with unmanned aerial vehicles. Ecosphere, 2014, 5(130), http://dx.doi.org/10.1890/ES14-00217.1.

[433] Asner GP, Powell GVN, Mascaro J, Knapp DE, Clark JK, Jacobson J, Kennedy-Bowdoin T, Balaji A, Paez-Acosta G, Victoria $E$, et al. High-resolution forest carbon stocks and emissions in the amazon. Proceedings of the National Academy of Sciences USA 2010, 107(38):16738-16742.

[434] Asner GP, Clark JK, Mascaro J, Galindo García GA, Chadwick KD, Encinales DNA, Paez-Acosta G, Montenegro EC, Kennedy-Bowdoin T, Duque A, et al High-resolution mapping of forest carbon stocks in the Colombian Amazon. Biogeosciences 2012, 9:2683 2696, 2012.

[435] Justice CO, Vermote E, Townshend JRG, Defries R, Roy DP, Hall DK, Salomonson VV, Privette JL, Riggs $G$, Strahler A, Lucht W, et al. The Moderate Resolution Imaging Spectroradiometer (MODIS): land remote sensing for global change research.IEEE, Transactions on Geosciences and Remonte Sensing,1998 36:1228 1249 .

[436] Guanter L, Zhang Y, Jung M, JoinerJ, Voig Mt, Berry JA, Frankenberg C, Huete AR, Zarco-Tejada $P$, Lee JE, et al. Global and time-resolved monitoring of crop photosynthesis with chlorophyll fluorescence. Proceedings of the National Academy of Sciences USA, 2014, 111(14):E1327 E1333, doi: $10.1073 /$ pnas.1320008111.

[437] Myneni RB, Hoffman S, Knyazikhin Y, Privette JL, Glassy J, Tian Y, Wang Y, Song X, Zhang Y, Smith GR, et al. Global products of vegetation leaf area and fraction absorbed PAR from year one of MODIS data. Remote Sensing of Environment 2002, 83:214 231. 
[438] Yang Y, Shang S, Guan H, and Jiang L. A novel algorithm to assess gross primary production for terrestrial ecosystems from MODIS imagery. Journal of Geophysical Research 2013, 118:590 605. doi:10.1002/jgrg.20056.

[439] Serbin SP, Singh A, McNeil BE, Kingdon CC, Townsend PA. Spectroscopic determination of leaf morphological and biochemical traits for northern temperate and boreal tree species. Ecological Applications, 2014, 24: 1651-1669.

[440] Knyazikhin Y, Schull MA, Stenberg P, Mottus M, Rautiainen M, Yang Y, Marshak A, Carmona PL, Kaufmann RK, LewisP, et al. Hyperspectral remote sensing of foliar nitrogen content. Proceedings of the National Academy of Sciences USA, 2012 , 3:E185 E192, doi:10.1073/pnas.1210196109.

[441] Homolová L, Malenovsky Z, Clevers JGPW, García-Santos G, and Schaepman ME. Review of optical-based remote sensing for plant trait mapping. Ecological Complexity 2013, 15:1 16.

[442] Brocca L, Hasenauer S, Lacava T, Melone F, Moramarco T, Wagner W, Dorigo W, Matgen P, Martínez-Fernández J, Llorens $\mathrm{P}$, Latron J, Martin C, and Bittelli M. Soil moisture estimation through ASCAT and AMSR-E sensors: An intercomparison and valida-tion study across Europe. Remote Sensing of Environment 2011, 115:3390 3408.

[443] Entekhabi D, Njoku EG, O'Neill PE, Kellogg KH, Crow WT, Edelstein WN, Entin JK, Goodman SD, Jackson TJ, Johnson J, et al. The soil moisture active passive (SMAP) mission. Proceedings of the IEEE, 98(5):704 716, 2010. doi:10.1109/JPROC.2010.2043918.

[444] Cox PM, Pearson D, Booth BB, Friedlingstein P, Huntingford C, Jones CD, and Luke CM. Sensitivity of tropical carbon to climate change constrained by carbon dioxide variability. Nature 2013, 494:341 344. doi:10.1038/nature11882.

[445] Frankenberg C, Pollock R, Lee RAM, Rosenberg R, Blavier JF, Crisp D, O'Dell CW, Osterman GB, Roehl C, Wennberg PO, and Wunch D. The Orbiting Carbon Observatory (OCO-2): spectrometer performance evaluation using pre-launch direct sun measurements. Atmos. Meas. Tech.2015, 8:301 313. doi:10.5194/amt-8-301-2015.

[446] McDowell NG, Ryan MG, Zeppel MJB, and Tissue DT. Improving our knowledge of droughtinduced forest mortality through experiments, observations, and modeling. New Phytologist, 2013, 200:289-293.

[447] Xu C, McDowell NG, Sevanto S, and Fisher RA. Our limited ability to predict vegetation dynamics under water stress. New Phytologist, 2013, 200:298-300.

[448] Fatichi S and Ivanov VY. Interannual variability of evapotranspiration and vegetation productivity. Water Resources Research 2014, 50:3275 3294. doi:10.1002/2013WR015044. 
[449] Tague CL, McDowell NG, and Allen CD. An integrated model of environmental effects on growth, carbohydrate balance, and mortality of pinus ponderosa forests in the southern rocky mountains. PLOS One 2013, 8(11):e80286.

[450] $\mathrm{Mu} \mathrm{Q}$, Zhao $\mathrm{M}$, and Running SW. Improvements to a MODIS global terrestrial evapotranspiration algorithm. Remote Sensing of Environment 2011, 115:1781 1800.

[451] Bornmann L, Mutz R. Growth rates of modern science: A bibliometric analysis based on the number of publications and cited references. Journal of the Association for Information Science and Technology, 2015. doi: 10.1002/asi.23329.

[452] Leitner D, Klepsch S, Bodner G, and Schnepf A. A dynamic root system growth model based on L-systems. Plant and Soil 2010, 332(1):177 192.

[453] Baldocchi DD and Wilson KB. Modeling $\mathrm{CO}_{2}$ and water vapor exchange of a temperate broadleaved forest across hourly to decadal time scales. Ecological Modelling 2001, 142:155 184.

[454] Nouvellon Y, Rambal S, Seen DL, Moran MS, Lhomme JP, Begue A, Chehbouni AG, and Kerr Y. Modelling of daily fluxes of water and carbon from shortgrass steppes. Agricultural and Forest Meteorology 2000. 100:137 153.

[455] Vertessy RA, Hatton TJ, R. Benyon G, and Dawes WR. Long-term growth and water balance predictions for a mountain ash (Eucalyptus regnans) forest catchment subject to clear-felling and regeneration. Tree Physiology 1996, 16:221 232.

[456] Battaglia M, Sands P, White D, and Mummery D. CABALA: a linked carbon, water and nitrogen model of forest growth for silvicultural decision support. Forest Ecology and Management 2004, 193:251282.

[457] Dufrêne E, Davi H, François C, le MaireG, Le Dantec V, and Granier A. Modelling carbon and water cycles in a beech forest Part I: Model description and uncertainty analysis on modelled NEE. Ecological Modelling 2005, 185:407 436.

[458] Govind A, Chen JM, Margolis H, Ju W, Sonnentag O, and Giasson MA. A spatially explicit hydroecological modeling framework (BEPS-TerrainLab V2.0): Model description and test in a boreal ecosystem in Eastern North America. Journal of Hydrology 2009, 367:200 216.

[459] Clark DB, Mercado LM, Sitch S, Jones CD, Gedney N, Best MJ, Pryor M, Rooney GG, Essery RLH, Blyth E, et al. The Joint UK Land Environment Simulator (JULES), model description - Part 2: Carbon fluxes and vegetation dynamics. Geosci. Model Dev. 2011, 4(3):701 722.

[460] Niu GY, Yang ZL, Mitchell KE, Chen F, Ek MB, Barlage M, Kumar A, Manning K, NiyogiD, Rosero $E$, Tewari $M$, and Xia $Y$. The community Noah land surface model with multiparameterization options 
(Noah-MP): 1. Model description and evaluation with local-scale measurements. Journal of Geophysical Research 2011, 116(D12109). doi:10.1029/2010JD015139.

[461] Levis S, Bonan GB, Vertenstein M, and Oleson KW. The Community Land Model's Dynamic Global Vegetation Model (CLMDGVM): Technical description and user's guide. Tech. note, NCAR/TN459+IA, Natl. Cent. for Atmos. Res., Boulder, Colorado, 2004.

[462] Lawrence DM, Oleson KW, Flanner MG, Thornton PE, Swenson SC, Lawrence PJ, Zeng X, Yang ZL, Levis S, Sakaguchi K, Bonan GB, and Slater AG. Parameterization improvements and functional and structural advances in version 4 of the Community Land Model. J. Adv. Model. Earth Syst 2011, 3(M03001). doi:10.1029/2011MS000045.

[463] Kucharik C, Foley J, Delire C, Fisher V, Coe M, Lenters J, Young-Molling C, Ramankutty N, Norman J, and Gower S. Testing the performance of a dynamic global ecosystem model: Water balance, carbon balance, and vegetation structure. Global Biogeochemical Cycles 2000, 14:795 825.

[464] Yang X, Wittig V, Jain AK, and Post W. Integration of nitrogen cycle dynamics into the integrated science assessment model for the study of terrestrial ecosystem responses to global change. Global Biogeochemical Cycles 2009, 23(GB4029), 2009. doi:10.1029/2009GB003474.

[465] Tian H, Chen G, Liu M, Zhang, C, Sun G, Lu C, Xu X, Ren W, Pan S, and ChappelkaA. Model estimates of net primary productivity, evapotranspiration, and water use efficiency in the terrestrial ecosystems of the southern United States during 1895-2007. Forest Ecol. Manage. 2010, 259(7):1311 1327.

[466] Thornton PE, Law BE, Gholz HL, Clark KL, Falge E, Ellsworth DS, Goldstein AH, Monson RK, Hollinger $D$, Falk $M$, Chen J, and Sparks JP. Modeling and measuring the effects of disturbance history and climate on carbon and water budgets in evergreen needleleaf forests. Agricultural and Forest Meteorology 2002, 113:185 222.

[467] Grant RF, Barr AG, Black TA, Margolis HA, Dunn AL, Metsaranta J, Wang S, McCaughey JH, and Bourque CA. Interannual variation in net ecosystem productivity of canadian forests as affected by regional weather patterns - A fluxnet-Canada synthesis. Agricultural and Forest Meteorology 2009, 149:2022 2039.

[468] Cox PM. Description of the TRIFFID Dynamic Global Vegetation Model. Technical Note 24, Hadley Centre, 2001.

[469] Sato H, Itoh A, and Kohyama T. SEIB-DGVM: A new Dynamic Global Vegetation Model using a spatially explicit individual-based approach. Ecological Modelling 2007, 200:279 307.

[470] Woodward FI and Lomas MR. Vegetation dynamics - simulating responses to climatic change. Biological Reviews 2004, 79:643 670, 2004. 
[471] Scheiter S, Langan L, and Higgins SI. Next-generation dynamic global vegetation models: learning from community ecology. New Phytologist 2013, 198:957 969.

[472] Keenan TF, Davidson E, Moffat A, Munger W, and Richardson AD. Using model-data fusion to interpret past trends, and quantify uncertainties in future projections, of terrestrial ecosystem carbon cycling. Global Change Biology 2012, 18:2555 2569. doi:10.1111/j.1365-2486.2012.02684.x.

[473] Carvalhais N, Reichstein M, Seixas J, Collatz GJ, J. Pereira S, Berbigier P, Carrara A, Granier A, Montagnani L, Papale D, et al. Implications of the carbon cycle steady state assumption for biogeochemical modeling performance and inverse parameter retrieval. Global Biogeochemical Cycles 2008, 22(GB2007). doi:10.1029/2007GB003033.

$=$

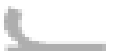

Figure captions

Fig. 1 Plant-water interactions are occurring over a broad range of spatial scales from (a) leaf interior $(\approx \mu \mathrm{m})$ to $(\mathrm{b})$ individual plant $(\approx \mathrm{m})$, to $(\mathrm{c})$ catchments $(\approx \mathrm{km})$ up to $(\mathrm{d})$ the entire Earth. Map of evapotranspiration on the Rietholzbach catchment ${ }^{25}$ and the annual global estimate of evapotranspiration from the MOD16 product ${ }^{450}$ are shown. (e)The increasing attention that is paid by the scientific community to ecohydrology is reflected in the number of published articles and the citations they received during the last 16 years (Source: ISI Web of knowledge, August 2015). The average increasing rate of publication in scientific literature is also shown as benchmark ${ }^{451}$. The MODIS map is reproduced by permission of Elsevier ${ }^{450}$, the leaf section is reproduced by permission of John Wiley and Sons ${ }^{71}$.

Fig. 2 A leaf is mostly composed of mesophyll and epidermal cells. The mesophyll is subdivided in palisade and spongy mesophyll. The epidermis secretes a waxy substance called the cuticle to separate leaf interior from the external atmosphere. Among the epidermal cells, there are pairs of guard cells. Each pair of guard cells forms a pore called stoma. Water and $\mathrm{CO}_{2}$ enter and exit the leaf mostly through the stomata. The vascular network of the plant is composed of xylem (blue) that transports water to the leaf cells and of phloem (red), which transports sugars from the leaf to the rest of the plant. Water that get off the xylem is evaporated in the leaf interior (dashed lines). The term $\Psi_{x, v} \Psi_{\mathrm{m}}, \Psi_{\mathrm{e}}, \Psi_{\mathrm{g}}, \Psi_{\mathrm{i}}$, and $\Psi_{\mathrm{a}}$ are the water potential in the xylem of leaf vein, mesophyll cell, epidermal cell, guard cell, leaf interior, and atmosphere, respectively. Stomatal aperture responds positively to guard cell turgor pressure $\left(\mathrm{P}_{\mathrm{g}}\right)$ and negatively to epidermal cell turgor pressure $\left(\mathrm{P}_{\mathrm{e}}\right)$ (hydromechanical feedback). The conductance of the stomatal aperture $\left(\mathrm{g}_{\mathrm{s}}\right)$ decreases with water potential in the leaf due to a combination of hydraulic and chemical factors.

Fig. 3 Representation of plant- and patch-scale root systems suitable for explicit 3-D hydraulic models of plant water and nutrient uptake. (a) Spatial distribution of tree stems and their root systems based on measurements at the University of Michigan Biological Station ${ }^{414}$ : the central dot is tress stem (diameter $\geq 10 \mathrm{~cm}$ ), the solid line shows the maximum lateral root extent, while the 
dashed line delineates distance corresponding to $95 \%$ of vertically and radially integrated root length. (b) Plant-scale properties of root distribution are controlled by using explicit root architecture obtained with the RootBox software ${ }^{452}$. Roots of different order (color-coded) as well as overlapped areas where competition for soil water and nutrients occurs are shown for three exemplary trees. (c) Patch-scale property of root distribution with depth is inferred from in situ observations of the bulk biomass density ${ }^{414}$ converted to the length density from variations of root diameters and specific density. For each depth, the median density, $25-75 \%$, and $10-90 \%$ ranges of the obtained distribution are shown.

Fig. 4 Global view of long-distance water and carbohydrate transport pathways in a vascular plant. The xylem mediates the net transfer of water from the soil to the atmosphere down a gradient in water potential, $\nabla \Psi$. The phloem carries a flow of sugars and other metabolites down the plant from the leaves to the tissues. Optical micrographs show cross sections of a leaf, stem, and root with the approximate location of the xylem (blue) and phloem (orange). Typical curves for changes in stem relative water content (RWC) and xylem cavitation expressed as Percentage Loss of Conductivity (PLC) as a function of water potential are shown along with the increase in fluid viscosity as a function of sucrose osmotic concentration. The figure is copied and adapted from ${ }^{66}$. Permission will be acquired for the final manuscript version.

Fig. 5. Effects on plant physiology caused by a decrease in water potential and turgor. The length of the horizontal lines represent the range of stress levels within which a process becomes first affected. Two different levels of minimum water potential $\Psi$ are given: -2 and $-12 \mathrm{MPa}$, these are indicative and correspond to a value characteristic for drought intolerant plants/crops and one for drought-adapted plants in deserts. Dashed lines signify an incipient or vanishing effect. The figure is inspired to Hsiao et al. $1976^{216}$ and Porporato et al. $2001^{18}$.

Fig. 6 Ecohydrological and terrestrial biosphere models have components and parameterizations to simulate the (i) surface energy exchanges; (ii) the water cycle, (iii) the carbon cycle and (iv) soil biogeochemistry and nutrient cycles. Many models do not include all the components presented in the figure.

Tables

Table 1. A non-exhaustive list of ecohydrological models. The presence or absence of specific processes is indicated with a yes $(\mathrm{Y})$ or no $(\mathrm{N})$ and with additional specifications.

\begin{tabular}{|c|c|c|c|c|c|c|c|c|c|}
\hline MODEL & Key Reference & $\begin{array}{l}\text { Water } \\
\text { Budget }\end{array}$ & $\begin{array}{l}\text { Energy } \\
\text { Budget }\end{array}$ & $\begin{array}{l}\text { Carbon } \\
\text { Pools }\end{array}$ & $\begin{array}{l}\text { Nutrie } \\
\text { nts }\end{array}$ & $\begin{array}{l}\text { Photosynthesi } \\
\text { s and stomatal }\end{array}$ & $\begin{array}{l}\text { Spatial } \\
\text { Represe } \\
\text { ntation }\end{array}$ & $\begin{array}{l}\text { Water } \\
\text { Routin } \\
\text { g }\end{array}$ & $\begin{array}{l}\text { Plant } \\
\text { spatial } \\
\text { dynam } \\
\text { ics } \\
\end{array}$ \\
\hline $\begin{array}{l}\text { T\&C } \\
\text { Tethys- } \\
\text { Chloris }\end{array}$ & $\begin{array}{l}\text { Fatichi et al } \\
\text { 2012; 2014, }\end{array}$ & $\begin{array}{l}\text { Y (Richards } \\
\text {-Multilayer) }\end{array}$ & $\begin{array}{l}\mathrm{Y}(1 \\
\text { prognostic } \\
\text { temp.) }\end{array}$ & $\begin{array}{l}\text { Y (7 } \\
\text { Pools) }\end{array}$ & $\mathrm{N}$ & $\begin{array}{l}\text { Y (Biochemical } \\
+ \text { Leuning) }\end{array}$ & Y (Grid) & Y & $\mathrm{N}$ \\
\hline
\end{tabular}




\begin{tabular}{|c|c|c|c|c|c|c|c|c|c|}
\hline $\begin{array}{l}\text { tRIBS- } \\
\text { VEGGIE }\end{array}$ & $\begin{array}{l}\text { Ivanov et al } \\
2008,160\end{array}$ & $\begin{array}{l}\text { Y (Richards } \\
\text {-Multilayer) }\end{array}$ & $\begin{array}{l}\text { Y }(2 \\
\text { prognostic } \\
\text { temp.) }\end{array}$ & $\begin{array}{l}\mathrm{Y}(4 \\
\text { pools })\end{array}$ & $\mathrm{N}$ & $\begin{array}{l}\text { Y (Biochemical } \\
+ \text { Leuning) }\end{array}$ & $Y(T I N)$ & $\mathrm{Y}$ & $\mathrm{N}$ \\
\hline MLCan & $\begin{array}{l}\text { Drewry et al } \\
2010,261\end{array}$ & $\begin{array}{l}\text { Y(Richards } \\
\text {-Multilayer) }\end{array}$ & $\begin{array}{l}\text { Y } \\
\text { (Multilayer } \\
\text { temp.) }\end{array}$ & $\mathrm{N}$ & $\mathrm{N}$ & $\begin{array}{l}\text { Y (Biochemical } \\
+ \text { Ball-Berry) }\end{array}$ & $\mathrm{N}$ & $\mathrm{N}$ & $\mathrm{N}$ \\
\hline RHESSys & $\begin{array}{l}\text { Tague and } \\
\text { Band 2004, } \\
\text { Tague et al } \\
2013,263,449\end{array}$ & $\begin{array}{l}\text { Y (Two } \\
\text { layers) }\end{array}$ & $\begin{array}{l}\mathrm{N}( \\
\text { Penman- } \\
\text { Monteith) }\end{array}$ & $\begin{array}{l}\text { Y (3 } \\
\text { pools) }\end{array}$ & $Y$ & Y( Empirical) & $\begin{array}{l}\text { Y (Semi- } \\
\text { distribute } \\
\text { d) }\end{array}$ & $Y$ & $\mathrm{~N}$ \\
\hline $\begin{array}{l}\text { CATHY/N } \\
\text { oahMP }\end{array}$ & $\begin{array}{l}\text { Niu et al } \\
2014,273\end{array}$ & $\begin{array}{l}\text { Y(Richards } \\
\text {-Multilayer) }\end{array}$ & $\begin{array}{l}\mathrm{Y}(2 \\
\text { prognostic } \\
\text { temp.) }\end{array}$ & $\mathrm{N}$ & $\mathrm{N}$ & r & $Y($ Grid $)$ & $\mathrm{Y}$ & $\mathrm{N}$ \\
\hline $\begin{array}{l}\text { PAWS }+C L \\
M\end{array}$ & $\begin{array}{l}\text { Shen et al } \\
2013,300\end{array}$ & $\begin{array}{l}\text { Y (Richards } \\
\text {-Multilayer) }\end{array}$ & $\begin{array}{l}\text { Y (3 } \\
\text { prognostic } \\
\text { temp.) }\end{array}$ & $\begin{array}{l}\text { Y }(4 \\
\text { Pools })\end{array}$ & $\mathrm{Y}$ & $\begin{array}{l}\text { Y (Biochemical } \\
+ \text { Leuning) }\end{array}$ & $Y($ Grid) & $Y$ & $\mathrm{~N}$ \\
\hline Geotop-dv & $\begin{array}{l}\text { Della Chiesa } \\
\text { et al 2014, }\end{array}$ & $\begin{array}{l}\text { Y (Richards } \\
\text {-Multilayer) }\end{array}$ & $\begin{array}{l}\mathrm{Y}(1 \\
\text { prognostic } \\
\text { temp.) }\end{array}$ & $\begin{array}{l}\text { Y( } 3 \\
\text { Pools) }\end{array}$ & $\mathrm{N}$ & $Y($ Empirical $)$ & $Y($ Grid $)$ & $\mathrm{Y}$ & $\mathrm{N}$ \\
\hline CATGraSS & $\begin{array}{l}\text { Zhou et al } \\
2013,{ }^{266}\end{array}$ & Y-Bucket & \begin{tabular}{|l|}
$\mathrm{N}($ \\
Penman- \\
Monteith) \\
\end{tabular} & $\begin{array}{l}Y(3 \\
\text { pools })\end{array}$ & $\mathrm{N}$ & Y( Empirical) & Y (Grid) & $\mathrm{N}$ & $\mathrm{Y}$ \\
\hline--- & $\begin{array}{l}\text { Van Wijk and } \\
\text { Rodriguez- } \\
\text { Iturbe 2002, } \\
311\end{array}$ & $Y$ (Bucket) & $\mathrm{N}$ & $\mathrm{N}$ & $\mathrm{N}$ & $1=0$ Tा & $\mathrm{Y}$ & $\mathrm{N}$ & $\mathrm{Y}$ \\
\hline VELMA & $\begin{array}{l}\text { Abdelnour et } \\
\text { al 2011, }\end{array}$ & $\begin{array}{l}\text { Y (Four } \\
\text { layers) } \\
\end{array}$ & $\begin{array}{l}\mathrm{N}(\text { Empiric } \\
\text { al) }\end{array}$ & $Y$ & $Y$ & $\mathrm{~N}$ & $Y$ & $Y$ & $\mathrm{~N}$ \\
\hline CANOAK & $\begin{array}{l}\text { Baldocchi and } \\
\text { Wilson 2001, } \\
453\end{array}$ & $\begin{array}{l}\text { Y(Multilayer } \\
\text { ) }\end{array}$ & $\begin{array}{l}\text { Y } \\
\text { (Multilayer } \\
\text { temp.) } \\
\end{array}$ & $\mathrm{N}$ & $\mathrm{N}$ & $\begin{array}{l}\text { Y (Biochemical } \\
+ \text { Ball-Berry) }\end{array}$ & $\mathrm{N}$ & $\mathrm{N}$ & $\mathrm{N}$ \\
\hline--- & $\begin{array}{l}\text { Nouvellon et } \\
\text { al 2000, } 454\end{array}$ & $\begin{array}{l}\text { Y (Three } \\
\text { layers) }\end{array}$ & \begin{tabular}{|l|}
$\mathrm{N}($ \\
Penman- \\
Monteith $)$ \\
\end{tabular} & $\begin{array}{l}Y(3 \\
\text { Pools) }\end{array}$ & $\mathrm{N}$ & Y (Empirical) & $\mathrm{N}$ & $\mathrm{N}$ & $\mathrm{N}$ \\
\hline VDM & $\begin{array}{l}\text { Montaldo et al } \\
2005,264\end{array}$ & Y (Bucket) & $\begin{array}{l}\mathrm{N}( \\
\text { Penman- } \\
\text { Monteith) }\end{array}$ & $\begin{array}{l}Y(3 \\
\text { Pools) }\end{array}$ & $\mathrm{N}$ & Y (Empirical) & $\mathrm{N}$ & $\mathrm{N}$ & $\mathrm{N}$ \\
\hline $\begin{array}{l}\text { Topog- } \\
\text { IRM }\end{array}$ & $\begin{array}{l}\text { Vertessy et al } \\
1996,455\end{array}$ & $\begin{array}{l}\text { Y (Richards } \\
\text {-Multilayer) }\end{array}$ & $\begin{array}{l}\mathrm{N}( \\
\text { Penman- } \\
\text { Monteith) }\end{array}$ & $\begin{array}{l}Y(3 \\
\text { pools })\end{array}$ & $\mathrm{N}$ & $\begin{array}{l}\text { Y (Empirical + } \\
\text { Leuning) }\end{array}$ & $\begin{array}{l}\text { Y ( Flow- } \\
\text { net) }\end{array}$ & $Y$ & $\mathrm{~N}$ \\
\hline --- & $\begin{array}{l}\text { Cervarolo et } \\
\text { al } 2010,{ }^{271}\end{array}$ & $\begin{array}{l}\text { Y (Richards } \\
\text {-Multilayer) }\end{array}$ & $\begin{array}{l}\text { Y (1 } \\
\text { prognostic } \\
\text { temp.) }\end{array}$ & $\begin{array}{l}Y(3 \\
\text { pools })\end{array}$ & $\mathrm{N}$ & $\begin{array}{l}\text { Y } \\
\text { (Empirical+Jarvi } \\
\text { s) }\end{array}$ & $Y($ Grid $)$ & $Y$ & $\mathrm{~N}$ \\
\hline CABALA & $\begin{array}{l}\text { Battaglia et al } \\
2004,456\end{array}$ & $Y$ (Bucket) & $\begin{array}{l}\mathrm{N}( \\
\text { Penman- } \\
\text { Monteith }\end{array}$ & $\begin{array}{l}Y(6 \\
\text { pools })\end{array}$ & $\mathrm{Y}$ & $\begin{array}{l}\text { Y (Biochemical } \\
+ \text { Ball-Berry) }\end{array}$ & $\mathrm{N}$ & $\mathrm{N}$ & $\mathrm{N}$ \\
\hline CenW 3.1 & $\begin{array}{l}\text { Kirschbaum } \\
\text { et al 2007, }\end{array}$ & $\begin{array}{l}\text { Y } \\
\text { (Multilayer) }\end{array}$ & $\begin{array}{l}\mathrm{N}( \\
\text { Penman- } \\
\text { Monteith }\end{array}$ & $\begin{array}{l}Y(10 \\
\text { pools })\end{array}$ & $Y$ & $\begin{array}{l}\text { Y (Biochemical } \\
+ \text { Ball-Berry) }\end{array}$ & $\mathrm{N}$ & $\mathrm{N}$ & $\mathrm{N}$ \\
\hline $\begin{array}{l}\text { CASTANE } \\
\text { A }\end{array}$ & $\begin{array}{l}\text { Dufrene et al } \\
2005,457\end{array}$ & $\begin{array}{l}\mathrm{Y}(\text { Three } \\
\text { layers) }\end{array}$ & $\begin{array}{l}\text { Y }(2 \\
\text { prognostic } \\
\text { temp.) }\end{array}$ & $\begin{array}{l}Y(5 \\
\text { pools })\end{array}$ & $\mathrm{N}$ & $\begin{array}{l}\text { Y (Biochemical } \\
+ \text { Ball-Berry) }\end{array}$ & $\mathrm{N}$ & $\mathrm{N}$ & $\mathrm{N}$ \\
\hline MuSICA & $\begin{array}{l}\text { Ogée et al } \\
2002,{ }^{259}\end{array}$ & $\begin{array}{l}\mathrm{Y}(\mathrm{Tw} \text { o } \\
\text { layers) }\end{array}$ & $\begin{array}{l}\text { Y }(1 \\
\text { prognostic } \\
\text { temp.) }\end{array}$ & $\mathrm{N}$ & $\mathrm{N}$ & $\begin{array}{l}\text { Y (Biochemical } \\
+ \text { Leuning) }\end{array}$ & $\mathrm{N}$ & $\mathrm{N}$ & $\mathrm{N}$ \\
\hline WEB-DHM & $\begin{array}{l}\text { Wang et al } \\
2009,{ }^{288}\end{array}$ & $\begin{array}{l}\text { Y (Richards } \\
\text {-Multilayer) }\end{array}$ & $\mathrm{Y}$ & $\mathrm{N}$ & $\mathrm{N}$ & $\begin{array}{l}\text { Y (Biochemical } \\
+ \text { Ball-Berry) }\end{array}$ & $Y$ (Grid) & $\mathrm{N}$ & $\mathrm{N}$ \\
\hline $\begin{array}{l}\text { BEPS- } \\
\text { TerrainLab }\end{array}$ & $\begin{array}{l}\text { Govind et al } \\
2009,458\end{array}$ & $\begin{array}{l}\mathrm{Y}(\mathrm{Tw} o \\
\text { layers }\end{array}$ & $\begin{array}{l}\mathrm{N}( \\
\text { Penman- } \\
\text { Monteith) }\end{array}$ & $\begin{array}{l}Y(4 \\
\text { Pools })\end{array}$ & $\mathrm{Y}$ & $\begin{array}{l}\text { Y (Biochemical } \\
+ \text { Empirical) }\end{array}$ & Y & $\mathrm{Y}$ & $\mathrm{N}$ \\
\hline
\end{tabular}


Table 2. A non-exhaustive list of terrestrial biosphere models. The presence or absence of specific processes is indicated with a yes $(\mathrm{Y})$ or no $(\mathrm{N})$.

\begin{tabular}{|c|c|c|c|c|c|c|c|c|c|}
\hline MODEL & $\begin{array}{l}\text { Key } \\
\text { Reference } \\
\end{array}$ & $\begin{array}{l}\text { Energy } \\
\text { Fluxes } \\
\end{array}$ & \begin{tabular}{|l} 
Water \\
Fluxes \\
\end{tabular} & $\begin{array}{l}\text { Carbon } \\
\text { model }\end{array}$ & $\begin{array}{l}\text { Nitrogen } \\
\text { Model }\end{array}$ & \begin{tabular}{|l} 
Plant \\
Establ./Mortality/Dis \\
turbances \\
\end{tabular} & $\begin{array}{l}\text { Carbon } \\
\text { reserves }\end{array}$ & \begin{tabular}{|l|} 
Root \\
exudatio \\
$\mathrm{n}$
\end{tabular} & $\begin{array}{l}\text { Mych } \\
\text { orrizal }\end{array}$ \\
\hline $\begin{array}{l}\text { CN- } \\
\text { CLASS }\end{array}$ & $\begin{array}{l}\text { Arain et al } \\
2006,{ }^{338}\end{array}$ & $Y$ & $Y$ & $Y$ & $Y$ & (a & $Y$ & $\mathrm{~N}$ & $\mathrm{~N}$ \\
\hline $\begin{array}{l}\text { JULES- } \\
\text { TRIFFID }\end{array}$ & $\begin{array}{l}\text { Clark et al } \\
2011,459\end{array}$ & $Y$ & $Y$ & $Y$ & $\mathrm{~N}$ & Y & $\mathrm{N}$ & $\mathrm{N}$ & $\mathrm{N}$ \\
\hline Noah-MP & \begin{tabular}{|l|} 
Niu et al \\
2011,460 \\
\end{tabular} & $Y$ & $Y$ & $Y$ & $\mathrm{~N}$ & $\mathrm{~N}$ & $\mathrm{~N}$ & $\mathrm{~N}$ & $\mathrm{~N}$ \\
\hline LPJ & $\begin{array}{l}\text { Sitch et al } \\
2003,{ }^{344}\end{array}$ & $\mathrm{~N}$ & $Y$ & $Y$ & $\mathrm{~N}$ & $Y$ & $\mathrm{~N}$ & $\mathrm{~N}$ & $\mathrm{~N}$ \\
\hline $\begin{array}{l}\text { ORCHID } \\
\mathrm{E}\end{array}$ & $\begin{array}{l}\text { Krinner et al } \\
2005,{ }^{345}\end{array}$ & $Y$ & $Y$ & $Y$ & $\mathrm{~N}$ & $Y$ & $Y$ & $\mathrm{~N}$ & $\mathrm{~N}$ \\
\hline $\begin{array}{l}\text { CLM- } \\
\text { DGVM }\end{array}$ & $\begin{array}{l}\text { Levis et al } \\
2004,461\end{array}$ & $Y$ & $Y$ & $Y$ & $\mathrm{~N}$ & $Y$ & $\mathrm{~N}$ & $\mathrm{~N}$ & $\mathrm{~N}$ \\
\hline $\mathrm{CLM} 4 \mathrm{CN}$ & $\begin{array}{l}\text { Lawrence et } \\
\text { al 2011, } 462\end{array}$ & $Y$ & $Y$ & $Y$ & $Y$ & $\mathrm{~N}$ & $\mathrm{~N}$ & $\mathrm{~N}$ & $\mathrm{~N}$ \\
\hline IBIS & $\begin{array}{l}\text { Kucharick et } \\
\text { al 2000, }{ }^{463}\end{array}$ & $Y$ & $Y$ & $Y$ & $Y$ & $Y$ & $\mathrm{~N}$ & $\mathrm{~N}$ & $\mathrm{~N}$ \\
\hline ISAM & $\begin{array}{l}\text { Yang et al } \\
2009,464\end{array}$ & $Y$ & $Y$ & $Y$ & $Y$ & $\mathrm{~N}$ & $\mathrm{~N}$ & $\mathrm{~N}$ & $\mathrm{~N}$ \\
\hline DLEM & $\begin{array}{l}\text { Tian et al } \\
2010,465 \\
\end{array}$ & $Y$ & $Y$ & $Y$ & $Y$ & $Y$ & $\mathrm{~N}$ & $\mathrm{~N}$ & $\mathrm{~N}$ \\
\hline $\begin{array}{l}\text { Biome- } \\
\text { BGC }\end{array}$ & $\begin{array}{l}\text { Thornton et } \\
\text { al } 2002,466\end{array}$ & $Y$ & $Y$ & $Y$ & $Y$ & $Y$ & $\mathrm{~N}$ & N & $\mathrm{N}$ \\
\hline ED2 & $\begin{array}{l}\text { Medvigy et al } \\
2009,\end{array}$ & Y & $Y$ & Y & $Y$ & $Y$ & $Y$ & $\mathrm{~N}$ & $\mathrm{~N}$ \\
\hline Ecosys & $\begin{array}{l}\text { Grant et al } \\
2009,467\end{array}$ & $Y$ & Y & $\mathrm{Y}$ & $Y$ & $\mathrm{~N}$ & $Y$ & $\mathrm{~N}$ & $Y$ \\
\hline $\begin{array}{l}\text { MOSES- } \\
\text { TRIFFID }\end{array}$ & ${ }_{468}$ Cox 2001, & $Y$ & $Y$ & Y & $\mathrm{N}$ & $Y$ & $\mathrm{~N}$ & $\mathrm{~N}$ & $\mathrm{~N}$ \\
\hline JSBACH & $\begin{array}{l}\text { Goll et al } \\
2012,340\end{array}$ & $Y$ & $Y$ & Y & $Y$ & $\mathrm{~N}$ & $Y$ & $Y$ & $\mathrm{~N}$ \\
\hline LPJ-DyN & $\begin{array}{l}\text { Xu-Ri and } \\
\text { Prentice } \\
2008,{ }^{283} \\
\end{array}$ & $\mathrm{~N}$ & $Y$ & $Y$ & $Y$ & $Y$ & N & $\mathrm{N}$ & $\mathrm{N}$ \\
\hline $\mathrm{O}-\mathrm{CN}$ & $\begin{array}{l}\text { Zaehle and } \\
\text { Friend 2010, } \\
\text { 284 }\end{array}$ & $Y$ & $Y$ & $\mathrm{Y}$ & $Y$ & $Y$ & $Y$ & $\mathrm{~N}$ & $\mathrm{~N}$ \\
\hline Hybrid3.C & $\begin{array}{l}\text { Friend et al } \\
1997,{ }^{275}\end{array}$ & $Y$ & $Y$ & $Y$ & $Y$ & $Y$ & $Y$ & $\mathrm{~N}$ & $\mathrm{~N}$ \\
\hline ANAFOR & $\begin{array}{l}\text { Deckmyn et } \\
\text { al 2008, } 163\end{array}$ & Y & $Y$ & Y & $\mathrm{Y}$ & $Y$ & $Y$ & $\mathrm{~N}$ & $\mathrm{~N}$ \\
\hline $\begin{array}{l}\text { SEIB- } \\
\text { DGVM }\end{array}$ & $\begin{array}{l}\text { Sato et al } \\
2007,469\end{array}$ & $\mathrm{~N}$ & $Y$ & Y & $\mathrm{N}$ & $Y$ & $Y$ & $\mathrm{~N}$ & $\mathrm{~N}$ \\
\hline $\begin{array}{l}\text { Sheffield } \\
\text { DGVM }\end{array}$ & $\begin{array}{l}\text { Woodward } \\
\text { and Lomas } \\
2004,{ }^{470}\end{array}$ & $\mathrm{~N}$ & $Y$ & $Y$ & $Y$ & $Y$ & $\mathrm{~N}$ & $\mathrm{~N}$ & $\mathrm{~N}$ \\
\hline $\begin{array}{l}\text { LPJ- } \\
\text { GUESS }\end{array}$ & $\begin{array}{l}\text { Smith et al } \\
2001,348\end{array}$ & $\mathrm{~N}$ & Y & Y & $\mathrm{N}$ & $Y$ & $N$ & $\mathrm{~N}$ & $\mathrm{~N}$ \\
\hline aDGVM2 & $\begin{array}{l}\text { Scheiter et al } \\
2013,{ }^{471}\end{array}$ & $\mathrm{~N}$ & $Y$ & $\mathrm{Y}$ & $\mathrm{N}$ & $Y$ & $\mathrm{~N}$ & $\mathrm{~N}$ & $\mathrm{~N}$ \\
\hline FoBAAR & $\begin{array}{l}\text { Keenan et al } \\
2012,472\end{array}$ & $\mathrm{~N}$ & $\mathrm{~N}$ & $Y$ & $\mathrm{~N}$ & $\mathrm{~N}$ & $Y$ & $\mathrm{~N}$ & $\mathrm{~N}$ \\
\hline
\end{tabular}




\begin{tabular}{|l|l|l|l|l|l|l|l|l|l|}
\hline CASA & $\begin{array}{l}\text { Carvalhais et } \\
\text { al } 2008,^{473}\end{array}$ & N & Y & Y & Y & N & N & N & N \\
\hline $\begin{array}{l}\text { JeDi- } \\
\text { DGVM }\end{array}$ & $\begin{array}{l}\text { Pavlick et al } \\
2013,{ }^{353}\end{array}$ & N & Y & Y & N & Y & Y & N & N \\
\hline
\end{tabular}

Table 3. List of variables that can be potentially observed at different scales.

\begin{tabular}{|c|c|c|}
\hline Scale & Variable & Instrument/Product \\
\hline Plant & Sapflow & Sap flow meter \\
\hline Plant & Leaf Water Potential & Pressure chamber \\
\hline Plant & Stem Water Potential & Psychrometer \\
\hline Plant/Stand & Tree/Branch Diameter & Forest Inventory \\
\hline Leaf $\equiv$ & Photosynthesis Stomatal conductance & Gas analyzers \\
\hline Leaf/Stand & Leaf/Canopy temperature & $\begin{array}{l}\text { IR Thermometers, Thermocouple, } \\
\text { Thermal cameras }\end{array}$ \\
\hline Leaf & Turgor & $\begin{array}{l}\text { Turgor probes or estimated from water } \\
\text { potential and osmolyte concentration }\end{array}$ \\
\hline Plant & Plant Respiration & Gas analyzers \\
\hline Plant & Stem water content & Coring, Moisture probe \\
\hline Stand & Evapotranspiration & Lysimeter, Flux-tower \\
\hline Point/Stand & Soil Respiration & Gas analyzers \\
\hline Plant/Stand/Global & Leaf Area Index & $\begin{array}{l}\text { Direct sampling, Optical sensors, } \\
\text { Remote Sensing }\end{array}$ \\
\hline Plant & $\begin{array}{l}\text { NSC dynamics (leaves and branches } \\
\text { and fine roots) }\end{array}$ & Sampling and laboratory analysis \\
\hline Point/Stand & $\begin{array}{l}\text { Soil water potential (tensiometers) and } \\
\text { volumetric water content }\end{array}$ & $\begin{array}{l}\text { Soil moisture probe and tensiometer, } \\
\text { Remote sensing }\end{array}$ \\
\hline Point/Stand & Soil temperature & Thermometers \\
\hline $\begin{array}{lll}\text { Stand } & -1\end{array}$ & Energy fluxes (LE, H) & Flux towers \\
\hline Stand & Carbon fluxes (NEE) & Flux towers \\
\hline Stand/Regional & Aboveground carbon stocks & Forest Inventories, Remote Sensing \\
\hline Stand/Regional & Tree Height & Forest Inventories, Remote Sensing \\
\hline Regional/Global & $\begin{array}{l}\text { Vegetation reflectivity Indices (NDVI, } \\
\text { EVI, chlorophyll fluorescence) }\end{array}$ & Remote Sensing \\
\hline Regional/Global & Surface temperature & Remote Sensing, IR Thermometers \\
\hline Regional/Global & $\mathrm{CO}_{2}$ anomalies & Remote Sensing, Stations \\
\hline Regional/Global & Albedo & Remote Sensing \\
\hline
\end{tabular}

\section{Further Reading/Resources}

[--]

\section{Acwnoledgements}

SF thanks the support of the Stavros Niarchos Foundation and the ETH Zurich Foundation (Grant ETH-29 14-2). VI acknowledges the support of NSF Grant EAR 1151443.

Related Articles

\begin{tabular}{|c|c|}
\hline DOI & \multicolumn{1}{|c|}{ Article title } \\
\hline & McDonnell Jeffrey J. The two water worlds hypothesis: ecohydrological \\
\hline
\end{tabular}




\begin{tabular}{|l|l|}
\hline $10.1002 /$ wat2.1027 & $\begin{array}{l}\text { separation of water between streams and trees? WIREs Water 2014, 1: 323- } \\
\text { 329. doi: 10.1002/wat2.1027 }\end{array}$ \\
\hline $10.1002 /$ wcc.83 & $\begin{array}{l}\text { Levis Samuel. Modeling vegetation and land use in models of the Earth } \\
\text { System. WIREs Clim Change 2010, 1: 840-856. doi: 10.1002/wcc.83 }\end{array}$ \\
\hline 10.1002/wcc.148 & $\begin{array}{l}\text { Flato Gregory M.. Earth system models: an overview. WIREs Clim Change } \\
\text { 2011, 2: 783-800. doi: } 10.1002 / \text { wcc.148 }\end{array}$ \\
\hline
\end{tabular}

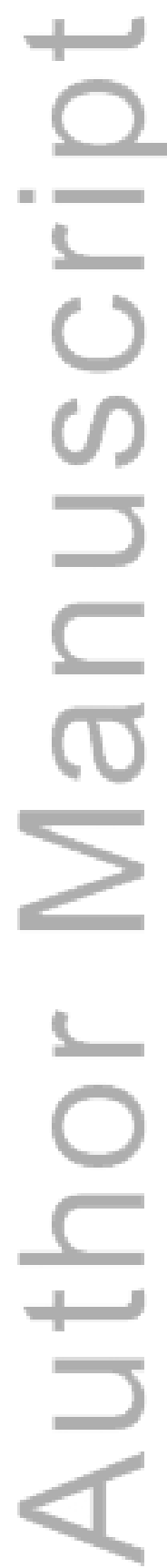

This article is protected by copyright. All rights reserved. 


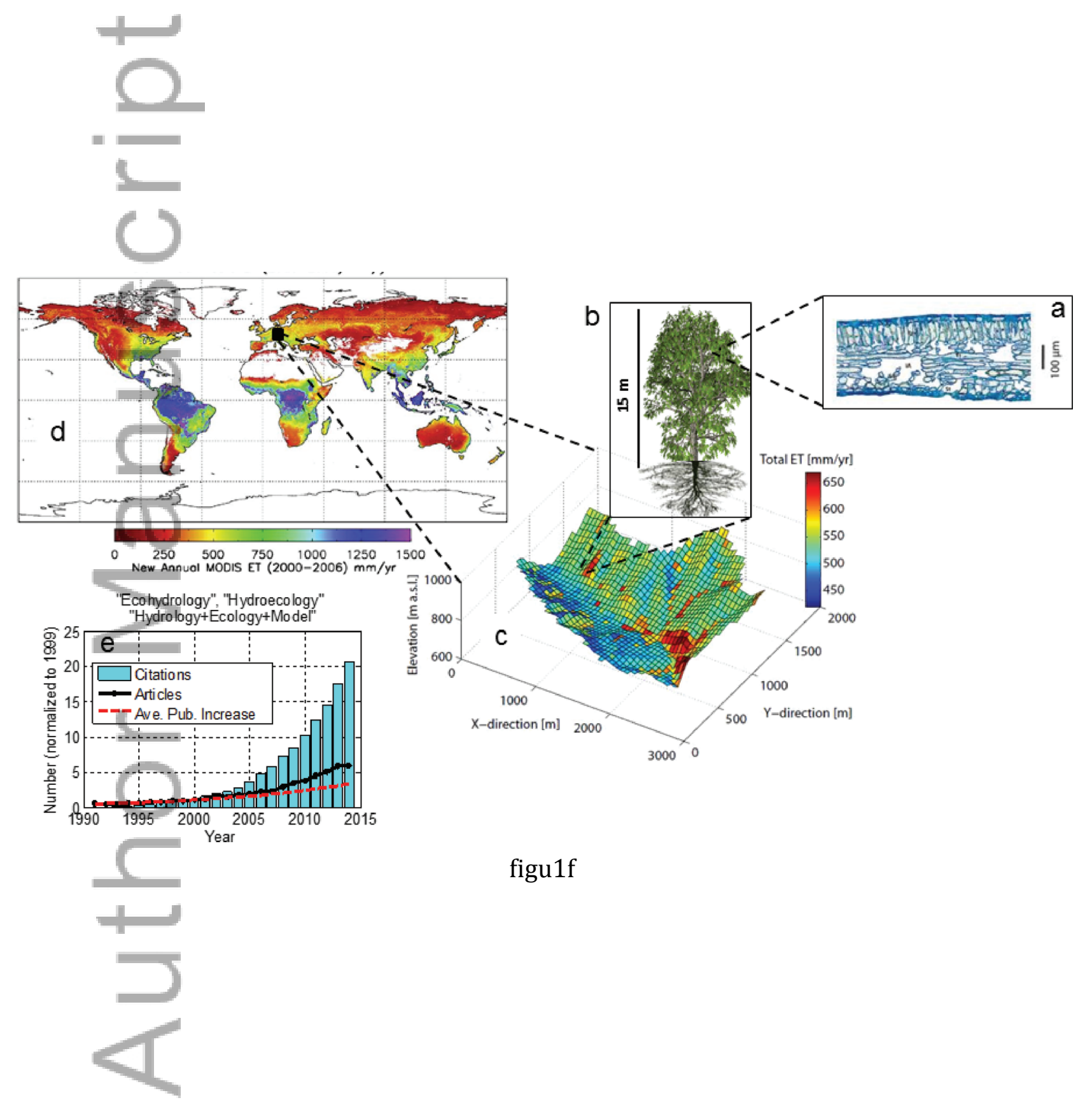

This article is protected by copyright. All rights reserved. 


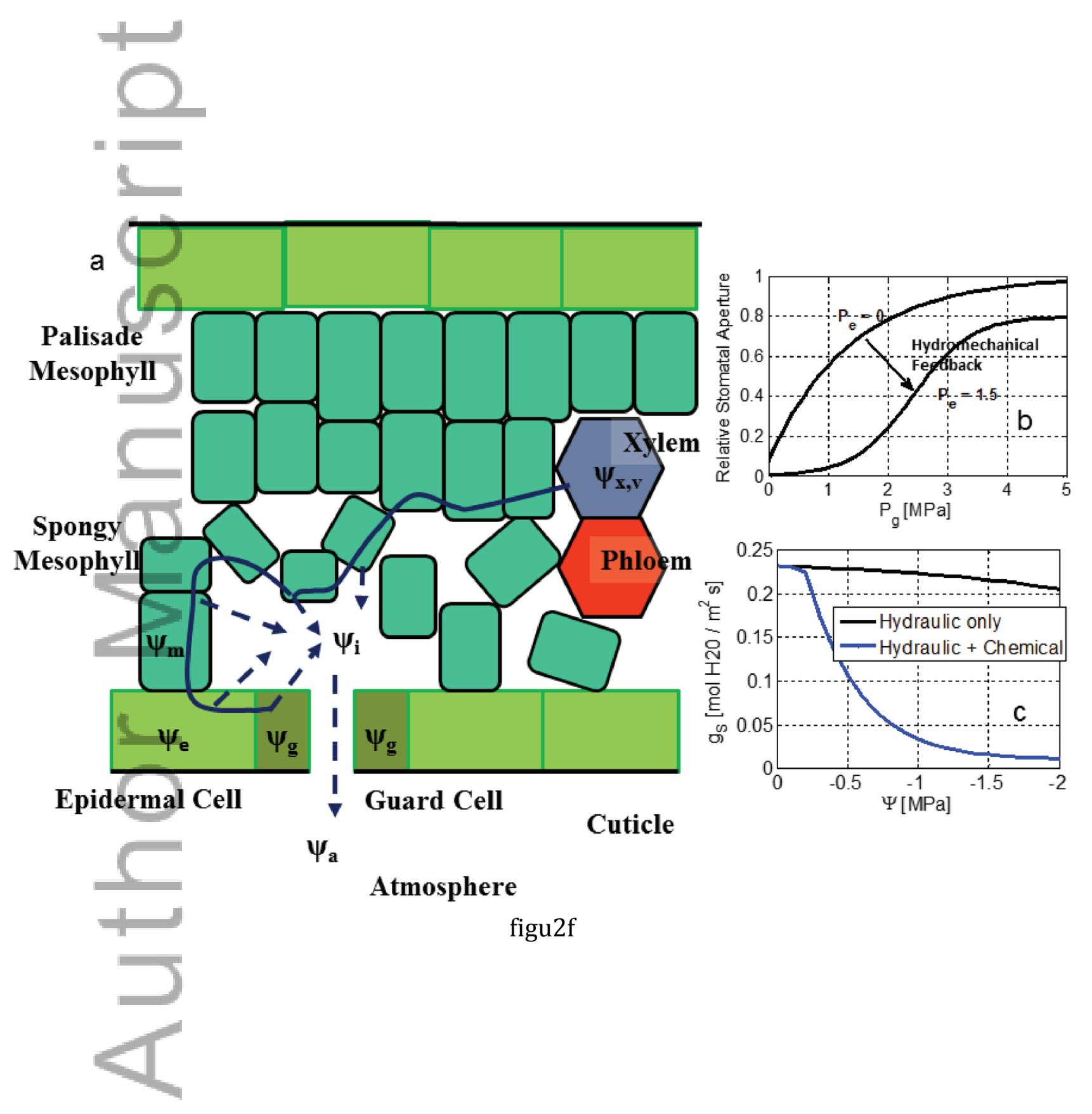

This article is protected by copyright. All rights reserved. 


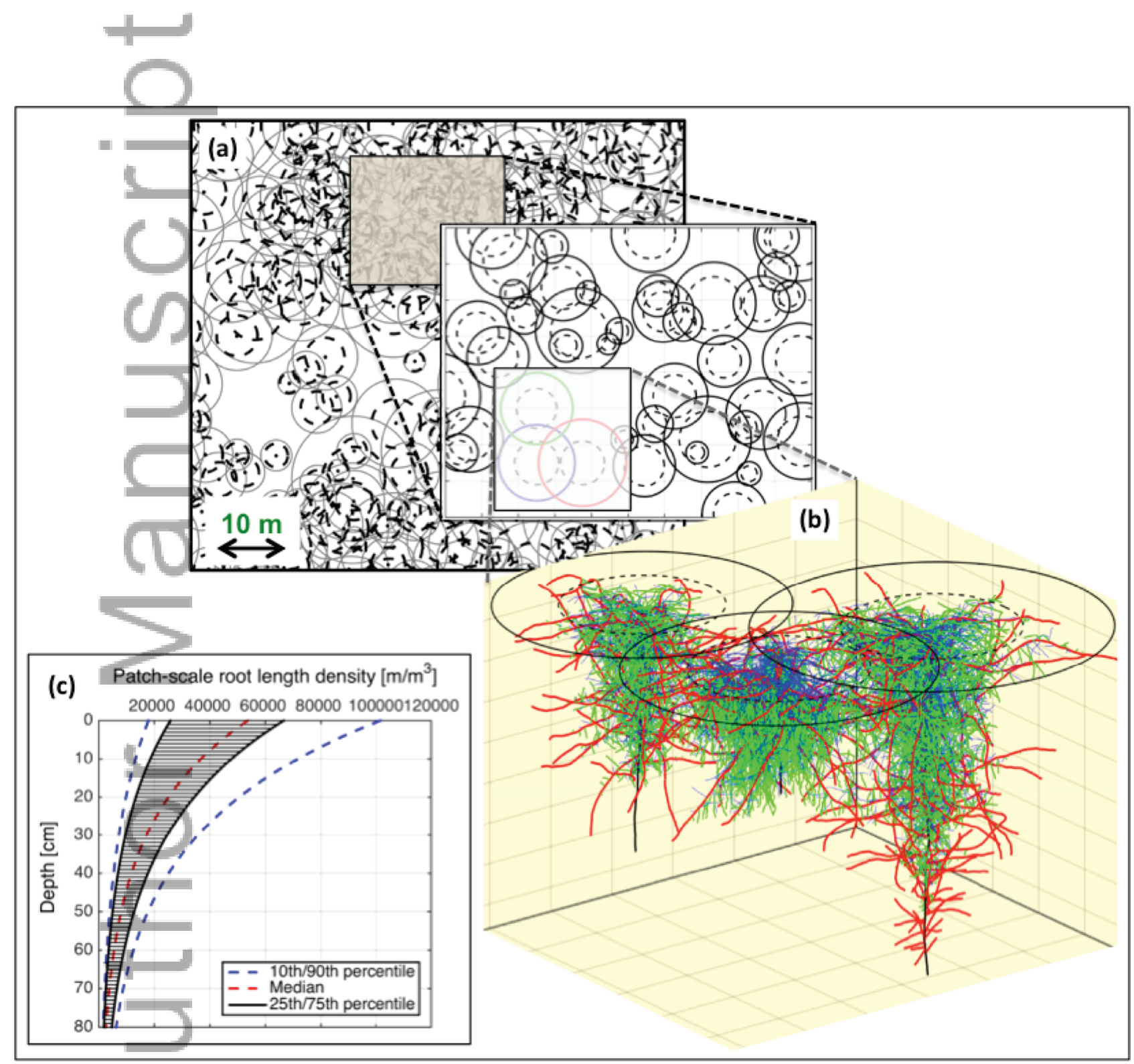

figu3f

This article is protected by copyright. All rights reserved. 


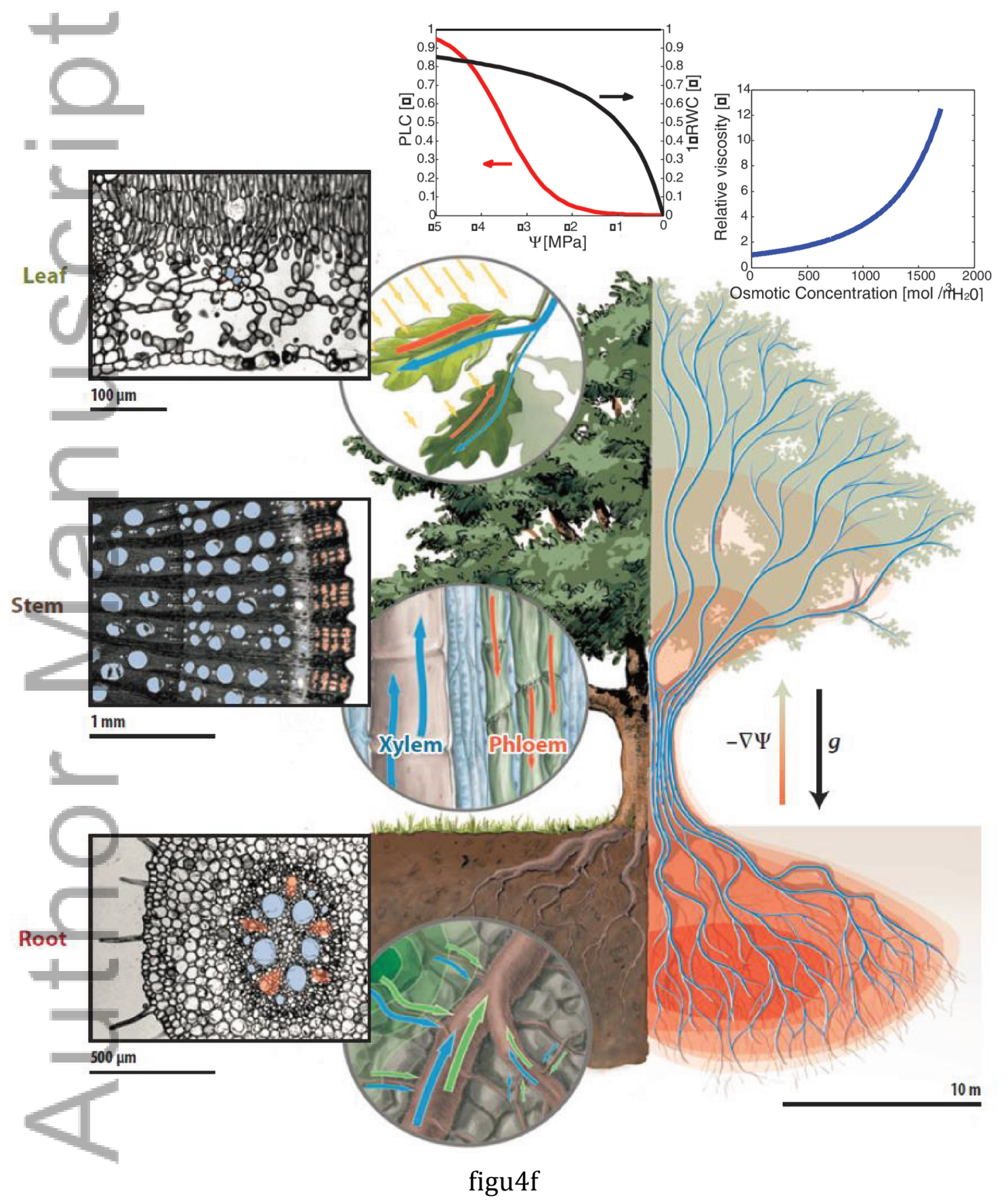

This article is protected by copyright. All rights reserved. 


\begin{tabular}{|l|c|}
\hline $\begin{array}{l}\text { Process or Variables } \\
\text { affected }\end{array}$ & \begin{tabular}{l} 
Reduction in Tissue Water Potential $\boldsymbol{\Psi}$ and Turgor $\mathbf{P}$ \\
\hline Cell growth
\end{tabular} \\
\hline Growth respiration & 0 \\
\hline ABA release & \\
\hline $\begin{array}{l}\text { Stomatal conductance } \\
\text { /Transpiration }\end{array}$ & \\
\hline Leaf energy budget & \\
\hline Photosynthesis & \\
\hline Xylem cavitation & \\
\hline $\begin{array}{l}\text { Root disconnection } \\
\text { rrom soil }\end{array}$ & \\
\hline $\begin{array}{l}\text { Maintenance } \\
\text { respiration }\end{array}$ & \\
\hline NSC transport & \\
\hline Leaf Turgortoss & \\
\hline Leaf shedding & \\
\hline Plant Mortality & \\
\hline
\end{tabular}

figu5f 
